Louisiana State University

LSU Digital Commons

Faculty Publications

Department of Chemistry

$1-1-2014$

\title{
Syntheses and functionalizations of porphyrin macrocycles
}

Maria da G.H. Vicente

Louisiana State University

Kevin M. Smith

Louisiana State University

Follow this and additional works at: https://digitalcommons.Isu.edu/chemistry_pubs

\section{Recommended Citation}

Vicente, M., \& Smith, K. (2014). Syntheses and functionalizations of porphyrin macrocycles. Current Organic Synthesis, 11 (1), 3-28. https://doi.org/10.2174/15701794113106660083

This Article is brought to you for free and open access by the Department of Chemistry at LSU Digital Commons. It has been accepted for inclusion in Faculty Publications by an authorized administrator of LSU Digital Commons. For more information, please contact ir@lsu.edu. 
Louisiana State University

LSU Digital Commons

Faculty Publications

Department of Chemistry

$1-1-2014$

\section{Syntheses and functionalizations of porphyrin macrocycles}

Maria da G.H. Vicente

Louisiana State University

Kevin M. Smith

Louisiana State University

Follow this and additional works at: https://digitalcommons.Isu.edu/chemistry_pubs

\section{Recommended Citation}

Vicente, M., \& Smith, K. (2014). Syntheses and functionalizations of porphyrin macrocycles. Current Organic Synthesis, 11 (1), 3-28. https://doi.org/10.2174/15701794113106660083

This Article is brought to you for free and open access by the Department of Chemistry at LSU Digital Commons. It has been accepted for inclusion in Faculty Publications by an authorized administrator of LSU Digital Commons. For more information, please contact ir@lsu.edu. 


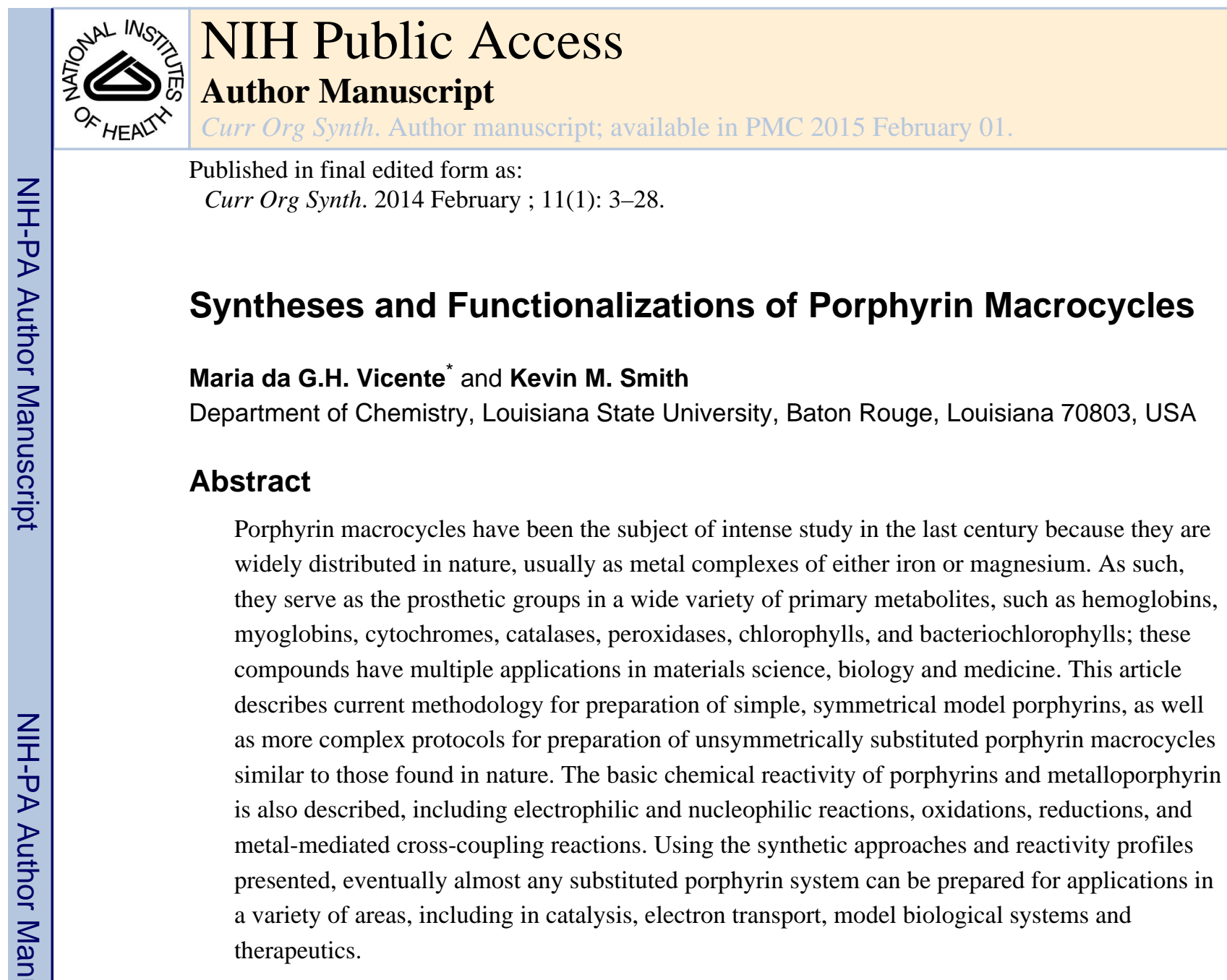

Keywords

Aromaticity; porphyrin; pyrrole; reactivity; substitutions; synthesis

\section{INTRODUCTION}

In this article we review the widely-used methodology which has been utilized to synthesize tetrapyrrole macrocycles in the porphyrin series from monopyrrole precursors; we also review selected porphyrin reactivity profiles.

\subsection{Monographs}

The porphyrin area has been honored, over time, with a significant number of Nobel prizes for its heroes, and is thus a research field that is rich in its history. Between 1934 and 1940 Hans Fischer and the Munich porphyrin group published three volumes that became a

\footnotetext{
(C) 2014 Bentham Science Publishers

*Address correspondence to this author at the Department of Chemistry, Louisiana State University, Baton Rouge, Louisiana 70803, USA; Tel: (+1225) 578-7405; Fax: (+1225) 578-3458; vicente@1su.edu.

CONFLICT OF INTEREST

The authors confirm that this article content has no conflict of interest.

DISCLOSURE

This article is an update of a previous article published in 2000 in Current Organic Chemistry VOLUME: 4 ISSUE: 2 DOI: $10.2174 / 1385272003376346$.
} 
roadmap for synthesis of porphyrin compounds [1-3]; in particular, these three volumes of Die Chemie des Pyrrols contained a compendium of laboratory methods. The tradition of laboratory methods within porphyrin monographs was continued in 1964 when Falk's book "Porphyrins and Metalloporphyrins" was published [4]; this contained a fairly detailed laboratory methods section but also attempted, for the first time, to apply modern principles of chemistry and electronic theory to the porphyrin field. This was followed in 1974 by a new version of "Porphyrins and Metalloporphyrins" (edited by one of us), which also contained a laboratory methods section, and then by Dolphin's more traditional series called "The Porphyrins" (1978-80). An authoritative and highly detailed description of the synthetic art of porphyrin chemistry and of reactivity profiles in the "octa-alkyl" and "tetraaryl" porphyrin series can be found in "The Porphyrin Handbook", which consists of two ten-volume sets containing no less than 122 chapters [5]. Since then, the follow-on series (30 volumes to date) by the same editors entitled "The Handbook of Porphyrin Science" has featured no less than six complete volumes with the word "synthesis" in their titles [6-11]. By and large, however, these more recent volumes [6-11] have dealt with syntheses of porphyrins with specific arrays of substituent for use in commercial applications, rather than on the development of new ways to synthesize the porphyrin core. A very thorough book dealing with syntheses and properties of porphyrin isomers, as well as contracted and expanded systems (outside the purview of this review) has also appeared [12].

\subsection{Nomenclature}

The Fischer system for nomenclature of porphyrins is shown in structure 1. Along with this simple numbering system, Fischer also created a host of trivial names for porphyrins [e.g. protoporphyrin (the "first" porphyrin), deuteroporphyrin (the "second" porphyrin), etioporphyrin] and for chlorophyll derivatives (chlorin- $\mathrm{e}_{6}$, rhoding $_{7}$, etc.). Fischer also created a "type" isomer system of nomenclature (see later for the etioporphyrin examples) which was used to define the nature of the substituent array in certain porphyrins. For example, a porphyrin made from tetramerization of a monopyrrole containing one methyl and one ethyl group can have four isomers - types I-IV. Enumeration of isomers of substituted porphyrins, and the construction of combinatorial libraries, has been authoritatively reviewed by Taniguchi and Lindsey [13]. The Fischer system for porphyrin nomenclature (structure 1) provides a link back to the rich history of porphyrin chemistry. As biosynthetic studies of vitamin $\mathrm{B}_{12}$ and porphyrins began to assume a dominant position in organic and biological chemistry, and as unique radiochemical and stable isotope labeling became the norm in these studies, it became necessary to identify every carbon atom in the porphyrin ring uniquely, but the Fischer system (1) leaves several carbon atoms unassigned; to be sure, these unassigned carbons never carry a substituent in a porphyrin, but they assumed importance as the biological origin of every carbon in porphyrins and vitamin $\mathrm{B}_{12}$ was investigated. The IUPAC subsequently adopted a system of nomenclature (structure 2); this is the officially adopted nomenclature system, and is used in this article (Fig. 1). 


\section{PORPHYRIN SYNTHESES}

A full description of all currently available routes to porphyrins is outside the scope of this brief article. Such a treatment can be found elsewhere [14]. Instead, with increasing complexity, three of the most typical synthetic approaches will be described.

The choice of which synthetic route to use to synthesize any particular porphyrin depends upon the symmetry features of the product itself. Syntheses of porphyrins by simple polymerization of monopyrroles will be discussed first; typical examples of porphyrins which can be made from this approach are octaethylporphyrin 3 and 5,10,15,20tetraphenylporphyrin 4 (Fig. 1). Next we shall progress to the so-called MacDonald route using two dipyrromethanes (the [2+2] approach) and one of its variants (the [3+1] method); porphyrins 5 and $\mathbf{6}$ are typical examples that can be approached synthetically in this way (Fig. 1). Finally, we shall finish the synthetic part of the article with porphyrin synthesis through cyclization of an open-chain tetrapyrrole (the so-called a,c-biladienes); this approach yields porphyrins such as $\mathbf{7}$, and is truly general because it possesses no symmetry restrictions.

A multitude of preparative routes to monopyrroles exist; reviews of this literature have been published [1,15-17]. Methods for elaboration of monopyrroles into dipyrromethane, tripyrrane, and a,c-biladiene compounds will be discussed in the sections related to the porphyrins in which they are used as essential intermediates.

Porphyrin syntheses from monopyrroles are best described with reference to two classical porphyrins - octaethylporphyrin (3; OEP) and tetraphenylporphyrin (4; TPP). Simply based on the symmetry properties of these two porphyrins, the most economical approach must involve some kind of monopyrrole tetramerization, either using monopyrroles bearing a 2substituent which can provide the four interpyrrolic carbons in the product, or using a 2,5-diunsubstituted monopyrrole with a separate reagent which will furnish the one-carbon bridging atoms. Attempting to synthesize OEP $\mathbf{3}$ by laborious multi-step construction of an open-chain tetrapyrrolic intermediate would be wasteful in time and resources.

\subsection{Porphyrins via Monopyrrole Tetramerization}

Everyone in the porphyrin field agrees that the easiest porphyrin to synthesize is TPP, 4. One simply needs to react pyrrole $\mathbf{8}$ with benzaldehyde under acidic conditions. The route was first reported by Rothemund [18, 19], who preferred to carry out the reaction in sealed glass tubes at high temperature. Roald Hoffmann has related to one of us that explosion of such a sealed glass tube converted him into a theoretician, and subsequently, a 1981 Nobel Laureate in Chemistry. A modification by Adler, Longo and their colleagues (involving use of refluxing propionic acid instead of sealed tube chemistry) [20], reproducibly affords a $20-25 \%$ yield of TPP from these simple shelf chemicals). This trivial procedure involves addition of equimolar amounts of pyrrole $\mathbf{8}$ and benzaldehyde to refluxing propionic acid (Scheme 1); after heating for about one half hour, the mixture is allowed to cool and the TPP is filtered off. The reaction also works with a limited number of substituted benzaldehydes that are able to survive refluxing propionic acid. The synthesis was finally optimized by Lindsey's group [21, 22], which showed that excellent yields of a wide variety of 
tetraarylporphyrins can be obtained using a high dilution two step reaction between arylaldehydes and pyrrole, in presence of a Lewis acid catalyst (usually $\mathrm{BF}_{3}$-etherate). In the second step of the reaction, the initial product (a colorless porphyrinogen, 9 ) is oxidized to porphyrin 4 using a quinone such as 2,3-dichloro-5,6-dicyanobenzoquinone (DDQ). Material isolated from the Rothemund and Adler/Longo approaches is highly crystalline but is nonetheless contaminated [23] with about $5 \%$ or less of 5,10,15,20-tetraphenylchlorin $\mathbf{1 0}$. Brief treatment [24] of the product with DDQ (which is the final step in the more recent Lindsey procedure) accomplishes transformation of $\mathbf{1 0}$ into $\mathbf{4}$; the separation of these two components by chromatography is much more demanding than is transformation of $\mathbf{1 0}$ into 4.

A majority of naturally occurring porphyrins (i.e. those not derived by degradation of chlorophylls or bacteriochlorophylls) do not contain meso-substituents, and there are certainly none that possess four such substituents. This has led many to question the utility of TPP as a "natural" mimic. Thus, over the years, OEP has been favored as a model for natural porphyrins more than has TPP. Synthetic approaches to porphyrins such OEP are a more complex because of the increased difficulty of preparing the 3,4-disubstituted pyrrole starting materials; pyrrole $\mathbf{8}$ can, of course simply be purchased and only needs to be distilled.

In the synthesis of TPP, the interpyrrolic carbons are provided by the aldehyde group of the corresponding arylaldehyde. In the case of octaalkylporphyrins (such as $\mathbf{3}$ ), the future meso(i.e. interpyrrolic) carbons can either be added separately by being not attached to the pyrrole (as for TPP) or can be already present in the form of a 2-substituent on the pyrrole. It is important to note that monopyrrole tetramerizations can only produce a structurally unique product if the 3- and 4-substituents in the monopyrrole are identical (Scheme 2).

There are two major routes to OEP 3. Firstly, tetramerization of 2,5-di-unsubstituted pyrroles in the presence of reagents which can provide the four meso methine carbons of the product can be used. Thus, cyclization of 3,4-diethylpyrrole 11 with formaldehyde affords $55-75 \%$ yields of OEP (3) (Scheme 2) [25]. Secondly, but in an approach which was chronologically developed first, tetramerization of pyrroles bearing $2-\mathrm{CH}_{2} \mathrm{R}$ substituents gives acceptable yields of porphyrin; the "R" group on the "benzylic" methylene must be a good leaving group because the methylene carbon will eventually be the source of the interpyrrolic carbons of the product after a nucleophilic attack upon it. Once the condensation reaction has taken place, an oxidation step is necessary in order to afford good yields of symmetrical porphyrin from an intermediate porphyrinogen. The required $\mathrm{CH}_{2} \mathrm{R}$ groups can be attached to pyrrolic intermediates by used of the Mannich reaction of pyrrole 11 with formaldehyde and dimethylamine [or with commercially available ( $N, N$ dimethylmethylene)ammonium iodide (Eschenmoser's reagent [26, 27])] to give the 2-(N,Ndimethylaminomethyl)pyrrole 12; heating of $\mathbf{1 2}$ in acetic acid affords about a 50\% yield of $\mathbf{3}$ (Scheme 2) [28, 29]. Alternatively, pyrrole $\mathbf{1 3}$ can be cyclotetramerized to give a similar yield of $\mathbf{3}$ by heating in acetic acid containing potassium ferricyanide [30, 31]. The BartonZard pyrrole synthesis [32] has afforded a very efficient access to monopyrroles of the type $\mathbf{1 4}$, which can be reduced (to the carbinol 15) and then tetramerized under acidic conditions to give 3 in high yield [33, 34]. 
Surprise is often expressed when relatively good yields of porphyrins are obtained from monopyrrole polymerizations - would not infinite linear polymers be preferred? If one constructs molecular models of the open-chain tetrapyrrole seco-porphyrinogen, one can see that once one has achieved an open-chain tetrapyrrole polymer (16) the head of the polymer is virtually biting the tail (Scheme 3).

This is particularly true if the monopyrrole precursor has fairly large 3-and 4-substituents because these enforce a helical geometry upon the elongating molecule. For this reason too, attempts to prepare the unsubstituted porphyrin $\mathbf{1 7}$ from pyrrole and formaldehyde usually gives a very low yield, probably due to a preference for infinite elongation due to the small 3- and 4-substituents in $\mathbf{8}$ (Scheme 4) and due to solubility problems of the product $\mathbf{1 7 .}$ However, several groups have synthesized substituted porphyrins and can be desubstituted and this simplifies the problems associated with the low solubility in almost all solvents, of 17. An example is the synthesis of the soluble tetra-tert-butylporphyrin $\mathbf{1 8}$ from the Mannich pyrrole 19, followed by removal of the four tert-butyl groups using aqueous sulfuric acid to give $\mathbf{1 7}$ in 64\% yield (Scheme 5) [35].

Monopyrrole tetramerization works best for pyrroles with identical 3- and 4-substituents. If the 3- and 4-substituents on the monopyrrole reactant are not identical, mixtures will usually result due to acid-catalyzed pyrrole ring scrambling reactions [13, 36]. As an example, and as mentioned earlier in this article, acid-catalyzed tetramerization of pyrrole $\mathbf{2 0}$ will result in a mixture of the four so-called etioporphyrin type isomers (21-24) (Scheme 6). With appropriate care to avoid acidic conditions, etioporphyrin I $\mathbf{2 1}$ can be obtained by tetramerization of a monopyrrole; pyrrole $\mathbf{2 5}$ has a leaving group which is labile even under neutral conditions [37, 38], and when reacted in methanol containing potassium ferricyanide gives a good yield of pure etioporphyrin I 21 (Scheme 7).

\subsection{The MacDonald [2+2] Porphyrin Synthesis}

The development of the so-called MacDonald synthesis was a game-changer for porphyrin synthesis [39]. At about the same time, Woodward and coworkers reported their landmark synthesis of chlorophyll-a that also employed a similar [2+2] approach in the fabrication of the initial porphyrin macrocycle [40].

Dipyrromethanes are the key intermediates in the MacDonald approach.

2.2.1. Syntheses of Dipyrromethanes-Dipyrromethanes can be synthesized using fairly straightforward methods. These important intermediates for porphyrin syntheses are categorized as either symmetrical or unsymmetrical about the interpyrrolic 5-carbon. Symmetrically substituted dipyrromethanes such as $\mathbf{2 6}$ can be prepared in one step by selfcondensation of bromomethylpyrroles such as $\mathbf{2 7}$ in hot methanol [41], or by heating 2acetoxymethylpyrroles such as $\mathbf{2 8}$ in methanol/hydrochloric acid [42]. The pyrrole $\mathbf{2 8}$ is obtained from the corresponding methylpyrrole 29 by oxidation of the 2-methyl with lead tetra-acetate. Catalytic hydrogenation cleaves the terminal benzyl esters to afford the corresponding 1,9-dicarboxylic acid $\mathbf{3 0}$ which can be formylated using the Vilsmeier reagent (dimethylformamide with either phosphoryl chloride or benzoyl chloride) to give $\mathbf{3 1}$ (Scheme 8). 
These two formyl groups provide the bridging carbons in the MacDonald [2+2] porphyrin macrocyclization (see later). Unsymmetrically substituted dipyrromethanes such as $\mathbf{3 2}$, are obtained by condensation of 2-acetoxymethylpyrroles, e.g. 33, with 2-unsubstituted pyrroles 34 in acetic acid and a catalytic amount of $p$-toluenesulfonic acid (Scheme 9) [43]. Montmorillonite K-10 clay has also been shown to be a very useful acid catalyst in dipyrromethane syntheses [44, 45].

Condensation of two unsymmetrical dipyrromethanes $\mathbf{3 5}$ and $\mathbf{3 6}$ with appropriate bridging carbons will result in two porphyrin products (37 and 38) because the dipyrromethanes can react in either of two orientations related by a $180^{\circ}$ rotation of one of the dipyrromethanes (Scheme 10).

These symmetry complications in a porphyrin synthesis involving an A-B and a C-D dipyrromethane can be avoided if the A-B or C-D dipyrromethane unit (only one of them!) is symmetrical about its interpyrrolic (5-) carbon atom. Thus, MacDonald and coworkers generically showed [39] that a symmetrical 1,9-diformyldipyrromethane such as $\mathbf{3 1}$, can be reacted with a 1,9-di-unsubstituted dipyrromethane $\mathbf{3 9}$ (obtained from $\mathbf{3 2}$ ), or the corresponding 1,9-dicarboxylic acid 40, in the presence of an hydriodic acid catalyst to give pure porphyrin, such as $\mathbf{4 1}$, in very high yields (Scheme 11). The method can be modified such that a monoformyldipyrromethane such as $\mathbf{4 2}$ is self-condensed to give centrosymmetrical porphyrins (e.g. 43) (Scheme 12). The initially formed intermediate is a porphodimethene salt $\mathbf{4 4}$; conversion to porphyrin requires an oxidation step that is usually provided by adventitious aerial oxygen; chemical oxidants such as $o$-chloranil or DDQ can also be used. Since MacDonald's report [39], others have shown that $p$-toluenesulfonic acid is a much better choice as the catalyst $[46,47]$.

A modification of the MacDonald [2+2] approach that avoids the final oxidation step has been published [48, 49]. Treatment of the 1,9-di-iododipyrromethane $\mathbf{4 5}$ with the known 1,9-diformyldipyrromethane $\mathbf{3 1}$ in acetic acid and acetic anhydride containing trifluoromethylsulfonic acid gave a 76\% yield of the diacetylporphyrin 46. Porphyrin $\mathbf{4 6}$ was then further transformed into hematoporphyrin-IX dimethyl ester $\mathbf{4 7}$ (by double reduction) and protoporphyrin-IX dimethyl ester $\mathbf{4 8}$ (by double dehydration of 47) (Scheme 13).

The [2+2] route using dipyrromethanes is probably the most widely used pathway to synthetic porphyrins.

\subsection{From Tripyrrolic Intermediates: The [3+1] Route}

The so-called [3+1] route to porphyrins employs the fundamental chemistry developed in the MacDonald approach. However, instead of condensing two dipyrromethanes (hence $[2+2])$, a tripyrrane $\mathbf{4 9}$ is reacted with a monopyrrole $\mathbf{5 0}$ bearing the two "bridging" carbon atoms. This macrocyclization of a 2,5-difunctionalized monopyrrole unit with an open-chain tripyrrole to produce a porphyrin $\mathbf{5 1}$ has a number of useful applications (Scheme 14).

It is often the case that the purpose of a particular porphyrin synthesis is to attach or conjugate the porphyrin to another species via unique functionality on the porphyrin. Thus, access to a uniquely functionalized point on the porphyrin will enable the application. Using 
the $[3+1]$ protocol permits efficient synthesis of a porphyrin in which the required functional handle group is situated on the monopyrrole component to be inserted at the final stage. This kind of chemistry has been facilitated by Sessler's recent advance in tripyrrane syntheses [50]. In its simplest form Sessler's route only yields symmetrically substituted tripyrranes, but the ease with which tripyrranes can be made using this method far outweighs the symmetry limitation. Thus, reaction of two equivalents of pyrrole $\mathbf{5 2}$ with pyrrole $\mathbf{5 3}$ affords the dibenzyl tripyrrane-1,14-dicarboxylate $\mathbf{5 4}$ in excellent yield. Catalytic debenzylation then affords the required tripyrrane-1,14-dicarboxylic acid $\mathbf{5 5}$ (Scheme 15).

The [3+1] approach has symmetry limitations because the terminal rings of the tripyrrane are usually identical. Removal of this limitation will require an advance in tripyrrane synthesis.

The first example of the [3+1] approach to porphyrins was reported by Boudif and Momenteau. A 2,5-diformylpyrrole and a tripyrrane were used [51]. Though the approach clearly has general applicability, Boudif and Momenteau targeted only bis-acrylic or bispropionic porphyrins, e.g. 56, from tripyrrane 57 and diformylpyrrole 58 (Scheme 16). Lash's group expanded the generality of the approach in their syntheses of porphyrins such as 59 (Fig. 2) [52]. Sessler and his group also showed the applicability of the approach and also reported syntheses of porphyrins such as $\mathbf{6 0}$ (Fig. 2) [53].

Our own group developed a [3+1] procedure which does not need acid catalysis, and which guarantees the integrity of the tripyrrane reactant against pyrrole ring-scrambling reactions [54]; treatment of tripyrrane 61, with the 2,5-bis( $N, N$-dimethylaminomethyl)pyrrole $\mathbf{6 2}$ in methanol containing ferricyanide gave the porphyrin 63, in good yield (Scheme 17).

\subsection{From a,c-Biladiene Salts}

The synthesis of a porphyrin (e.g. 7) with a completely unsymmetrical array of substituents must progress through open-chain tetrapyrrolic intermediates. Though a number of openchain tetrapyrroles have been investigated and utilized with success [14] over the years, the most used open-chain precursors of choice have been shown to be 1,19-dimethyl-a,cbiladiene salts such as 64 .

Symmetrical 1,19-dimethyl-a,c-biladienes, e.g. 64, can be synthesized by condensation of dipyrromethane-1,9-dicarboxylic acids 30 with two equivalents of a 2-formyl-5methylpyrrole 65. The method of choice in earlier studies for cyclization of the a,c-biladiene to give porphyrin, always as its copper(II) complex 66, has involved use of copper(II) chloride or acetate in hot dimethylformamide. Demetalation with $\mathrm{H}_{2} \mathrm{SO}_{4} / \mathrm{TFA}$ then affords, for example, the metal free porphyrin $67[55,56]$ (Scheme 18). Other cyclization protocols have been studied [57-65] including other metal salts or even electrochemical oxidation. The mechanism of this cyclization, which involves loss of (at least) one of the terminal methyl groups of the a,c-biladiene is not immediately obvious, and a full review of the evidence and conclusions has been published [56]. A breakthrough in the mechanistic investigation of a,cbiladiene cyclizations was achieved when it was shown $[56,60,61]$ that electrochemical oxidation of, for example, a,c-biladiene dihydrobromide 68 proceeds to give metal free porphyrin 69 via the cyclic dihydroporphyrin intermediate 70 (Scheme 19) which then 
eliminates the quaternary methyl group (presumably by an $\mathrm{S}_{\mathrm{N}} 2$ attack that involves the newly aromatized porphyrin as the leaving group) after macrocyclization.

The electrochemical cyclization $[60,61]$ has the advantage that it gives the metal free porphyrin (e.g. 69) as the product, thereby eliminating the need to treat the copper(II) complex [from the copper(II) chloride route] with concentrated sulfuric and trifluoroacetic acids. Also, the reaction progress can be monitored using ${ }^{1} \mathrm{H}-\mathrm{NMR}$ spectroscopy in the absence of the paramagentic copper(II) ion. But scaling-up of electrochemical reactions to preparative quantities is not easy. However, it has been found that use of chromium(III) for the oxidative cyclization results in the production of the metal-free porphyrin product [66]. Many researchers had assumed that the metal salts used in these cyclization provided template around which the a,c-biladiene, or some subsequent intermediate on the pathway to porphyrin, could assemble. Recent results however show [65] that the primary function of the metal ion is oxidation, and not templation, and this is also confirmed by the success of the electrochemical approach that uses no transition metal salts at all. Several mechanistic studies [57-59], and experiments involving oxidation with different metal ions have been published, and these have been reviewed and analyzed [56].

Symmetry limitations associated with the earlier a,c-biladiene syntheses were removed by development of routes to unsymmetrically substituted a,c-biladienes [14, 67, 68]. There now exists two complementary methods, which involve "clockwise" or "counterclockwise" elongation of the developing a,c-biladiene (Scheme 20). The counterclockwise route was developed first [67] and involves catalytic hydrogenation of a benzyl tert-butyl dipyrromethane-1,9-dicarboxylate $\mathbf{3 2}$ to give a monocarboxylic acid $\mathbf{7 1}$ which reacts under mild conditions with a 2-formyl-5-methylpyrrole $\mathbf{6 5}$ to afford a high yield of a so-called tripyrrene salt 72. Treatment with TFA (which serves to cleave the tert-butyl ester) and a second, different 2-formylpyrrole 73, gives a high yield of 1,19-dimethyl-a,c-biladiene salt 74 with a completely unsymmetrical array of substituents; cyclization using, for example, the copper(II) method, followed by demetalation with concentrated sulfuric acid in trifluoroacetic acid gives the porphyrin 75. Any other method for cyclization, e.g. the chromium(III) method $[54,66]$, or electrochemical methods $[60,61]$ which give directly the metal free porphyrin can be used.

The second, so-called clockwise approach (Scheme 20), involves [68] treatment of the dipyrromethane mixed ester 32 with TFA to give the dipyrromethane 76; treatment with formylpyrrole $\mathbf{7 3}$ affords the tripyrrene salt 77. Catalytic hydrogenation cannot be used for cleavage of the benzyl ester because this would also saturate the tripyrrene double bond. Thus, sulfuric acid/ $\mathrm{HBr}$ is used, and this is followed by addition of formylpyrrole $\mathbf{6 5}$ to give the a,c-biladiene salt 74, identical with that obtained using the other tripyrrene route. a,cBiladiene cyclization proceeds as earlier to give porphyrin. There is an advantage to having two different routes to the same a,c-biladiene and porphyrin, particularly when very valuable monopyrroles are being used (e.g. carbon-13 or carbon-14 labeled) and good synthetic strategy requires that this precious pyrrole be added in the last possible step.

1,19-Dimethyl-a,c-biladienes are highly effective intermediates for porphyrin synthesis; good yields of porphyrin are obtained and there are no obvious symmetry or substituent 
difficulties. The use of a,c-biladienes bearing 1- and 19-substituents other than methyls [62-65] has been investigated, and these reactions yield the predictable meso-substituted porphyrins, along with a host of macrocycles in which either the 1- or the 19-substituent in the original a,c-biladiene has migrated around the macrocycle. These results are also discussed in detail elsewhere [56, 62-65].

\section{PORPHYRIN FUNCTIONALIZATION}

The porphyrin macrocycle contains 22 conjugated $\pi$-electrons, but only 18 of these are required for its conjugated aromatic network. As a consequence, porphyrins can undergo additions and substitution reactions without loss of their aromaticity, as well as crosscouplings, oxidations and reductions, to produce a variety of functionalized macrocycles and linear tetrapyrroles, that continue to find multiple applications in biology, medicine and materials science.

The most electronically reactive positions at the porphyrin periphery are the meso-positions, and generally the preferential sites for electrophilic aromatic substitutions, additions and radical reactions. On the other hand, the $\beta$-pyrrolic positions are the most sterically accessible and can also undergo the same type of reactions. Substitution, cross-couplings and radical reactions have been used to produce a variety of functionalized porphyrins, whereas additions to $\beta-\beta$ ' peripheral double bonds lead to the formation of chlorins, bacteriochlorins, or isobacteriochlorins, and to the meso positions produce phlorins, porphodimethenes, and expanded tetrapyrrolic macrocycles. The inner pyrrolenine nitrogen atoms of porphyrins can be protonated to give the corresponding mono- or di-cations, and the NH groups can be deprotonated to produce di-anions. Porphyrins can also be readily metalated with a wide variety of metal ions and all the naturally occurring porphyrins are metal complexes. The metal ions have an important inductive effect on the $\pi$-electron system and strongly influence the chemical reactivity, photophysical properties and biological functions of porphyrin macrocycles. Closed-shell configuration metals incapable of $\mathrm{d} \pi-\mathrm{p} \pi$ back-bonding, such as $\mathrm{Zn}(\mathrm{II})$ and $\mathrm{Cd}(\mathrm{II})$, induce the highest negative charge onto the porphyrin periphery, conferring them the lowest one-electron oxidation potentials. On the other hand, metals capable of $\pi$-back-bonding decrease the electron density on the macrocycle, for example $\mathrm{Cu}$ (II) and $\mathrm{Ni}$ (II) with $\mathrm{d}^{6}-\mathrm{d}^{9}$ configurations, and in particular metals with $\mathrm{d}^{1}-\mathrm{d}^{5}$ configurations, such as $\mathrm{Sn}(\mathrm{IV})$ and $\mathrm{Fe}(\mathrm{III})$, strongly reduce the electron density at the porphyrin periphery.

\subsection{Halogenation and $\operatorname{Pd}(0)$-Catalyzed Coupling Reactions}

Electron-rich porphyrins normally undergo electrophilic reactions at unsubstituted peripheral positions, when the inner pyrrolenine nitrogens are "protected" by metalalation. Fluorination reagents include $N$-fluoropyridinium triflates [69], cesium fluoroxysulfate [70], and fluorides of cobalt or silver [71]. $N$-Chlorosuccinimide (NCS) [72-77] or chlorine [64, 65] are normally used for chlorination, although $\mathrm{HCl} / \mathrm{H}_{2} \mathrm{O}_{2}$ [78] and $\mathrm{PhSeCl}_{3}$ [79] have also been reported. Similarly, $N$-bromosuccinimide (NBS) [63, 64, 67, 80-84], bromine [64, 73, 85, 86], $\mathrm{HBr} / \mathrm{H}_{2} \mathrm{O}_{2}$ [66, 71], copper(II) bromide [85] and $\mathrm{PhSeBr}_{3}$ [69] have been used for bromination of porphyrin macrocycles. Polybromination can lead to mixtures of regioisomers when unsubstituted $\beta$ - and meso-positions are available at the macrocycle 
periphery. Nevertheless, in the case of meso-tetraarylporphyrins, such as TPP 4, tetrabromination can be achieved regioselectively using a slight excess of NBS in refluxing $\mathrm{CHCl}_{3}$, leading to the corresponding 2,3,12,13-tetrabromoporphyrins, such as $\mathbf{7 8}$ in about 80\% yield (Scheme 21) [88].

This regioselectivity is only observed in metal-free porphyrins, where bond fixation occurs after the first substitution, therefore promoting bromination on antipodal pyrrolic units. $\beta$ Octabromination can also be obtained using an excess NBS in refluxing $o$-dichlorobenzene or bromine in chloroform/carbon tetrachloride; in this case the best yields are obtained with the metal complexes of porphyrins (usually $\mathrm{Cu}$, which can be demetalated under acid conditions) due to their higher stability under the reaction conditions, to produce e.g. 79 [89]. Mono- and di-iodination have been accomplished with bis(trifluoroacetoxy)iodobenzene-iodine in chloroform/pyridine [90, 91]. Using meso-5,15-diphenylporphyrin 80, the first iodination occurs selectively at one of the free meso-positions while the second substitution occurs at one of the $\beta$ positions leading to a mixture of diiodo regioisomers. However, the meso-dibrominated porphyrin $\mathbf{8 1}$ can be obtained in high yield (96\%) and regioselectively, by reacting $\mathbf{8 0}$ with NBS in chloroform and pyridine at $0{ }^{\circ} \mathrm{C}$ for one hour (Scheme 22) [92]. Two different halogens can also be inserted into porphyrin $\mathbf{8 0}$ by performing consecutive bromination and iodination reactions (in this order), giving porphyrin 82 in 66\% yield [80]. Regioselective di-iodination was also accomplished when bulky meso-aryl groups are present, such as in 5,15-di(3',4',5'-trimethoxyphenyl)porphyrin $\mathbf{8 3}$, the meso-diiodo porphyrin $\mathbf{8 4}$ is obtained regioselectively (Scheme 23).

Side reactions of brominations and iodinations have been reported, via the formation of porphyrin $\pi$-cation radicals, which can react in multiple ways. For example, OEP 3 reacted with NBS in the presence of 2,2'-azobis(2-methylpropionitrile) (AIBN) to produce trans-(2bromovinyl)porphyrin $\mathbf{8 5}$ (Scheme 24) by way of a (1-bromoethyl) intermediate, which can be trapped as the ether derivative in the presence of alcohols $[66,93]$.

The nucleophilic substitution of halogen substituents has also been reported, by for example cyanide [76, 94, 95], nitrite [96], and thiolate ions [88]. The main use of bromo- and iodoporphyrins is as starting materials for cross-coupling reactions, via palladium(0)-catalyzed Suzuki, Sonogashira, Heck and Stille type reactions to produce various aryl, ethynyl and alkenyl-functionalized porphyrin systems; dimeric and oligomeric porphyrin systems have also been prepared using these methodologies [97-108]. For example, dodecaarylporphyrins 86 were prepared in $14-65 \%$ yields using a Suzuki coupling reaction of metal-free 79 with arylboronic acids (Scheme 25) [109-111].

This methodology has been used to produce a variety of functionalized porphyrins, for example carborane-containing porphyrin 87 in $78 \%$ from bromoporphyrin $\mathbf{7 8}$ (Scheme 26) [112] and carboxylate-functionalized $\mathbf{8 8}$ from $\mathbf{8 0}$ (Scheme 27) [70, 81].

Metalloporphyrins are often used in palladium(0)-catalyzed coupling reactions to avoid macrocycle metalation by palladium and/or copper, sometimes used as co-catalyst. Allenylboronate has also been used to produce allenyl and alkynyl-functionalized porphyrins from the corresponding bromoporphyrins [113]. Both meso- and $\beta$ - 
bromoporphyrins have been functionalized by palladium(0)-catalyzed couplings with amines, amides, alcohols, sulfides, carbazates, hydrazones and phosphines [114-123]. Examples are the synthesis of porphyrins 89 [88] and 90 [102] from 81 or its zinc(II) complex (Scheme 27).

Brominated porphyrins have also been coupled with iodo-alkyl fluorides in the presence of tris(dibenzylideneacetone)dipalladium(0), triphenylarsine and copper(0) in DMSO to produce meso- and $\beta$-perfluoroalkylated porphyrins in $40-85 \%$ yields [124], and with potassium organotrifluoroborates in the presence of $\mathrm{Pd}(\mathrm{dppf}) \mathrm{Cl}_{2}$ and $\mathrm{Cs}_{2} \mathrm{CO}_{3}$ to produce a variety of functionalized porphyrins [125].

Suzuki-type couplings have also been performed on borylated porphyrins, which can be prepared from palladium-catalyzed reactions of bromoporphyrins with pinacol borane or bispinacol borane. Borylated porphyrins undergo a variety of palladium-catalyzed coupling reactions with aryl halides [126-132]. One example is the borylation of the zinc(II) complex of meso-diphenylporphyrin $\mathbf{8 0}$, followed by palladium(0)-catalyzed coupling to $N$-Boc protected 4-iodo-phenylalanine to give porphyrin 91 (Scheme 28) [112].

Sonogashira coupling reactions are used for the preparation of a variety of ethynylsubstituted porphyrins, usually by reaction of a meso- or $\beta$-halogenated porphyrin with acetylene compounds [117, 133-138]. Using this methodology, the zinc(II) complex of diiodoporphyrin $\mathbf{8 4}$ was converted into ethynylporphyrins $\mathbf{9 2}$ in $25-72 \%$ yields (Scheme 29) [81], and nickel(II)-porphyrin $\mathbf{8 1}$ gave $\mathbf{9 3}$ in $66 \%$ yield upon coupling with ferrocenylethyne (Scheme 30) [119].

Different functionalizations can be introduced onto a porphyrin by performing successive halogenation-coupling-halogenation-coupling reactions or by taking advantage of the different reactivity of two halogens (e.g. Br and I) that are first introduced into the macrocycle, followed by two coupling reactions. For example, porphyrins 94 were prepared from zinc(II) porphyrin $\mathbf{8 2}$ by consecutive Sonogashira and Stille coupling reactions (Scheme 31) [81]. An interesting cross-annulative coupling reaction has also reported between meso-diarylporphyrin $\mathbf{9 5}$ and various acetylenes in the presence of $\operatorname{Pd}_{2}(\mathrm{dba})_{3}$, tris (o-tolyl)phosphine and dicyclohexylmethylamine in refluxing toluene, to give porphyrins 96 in $78-87 \%$ yields (Scheme 32) [139].

Heck and Stille coupling reactions are used to prepare alkenyl and aryl-substituted porphyrins [140-144]. Stille-type reactions were first used in porphyrin functionalization for the preparation of protoporphyrin IX dimethyl ester $\mathbf{9 8}$ from dibromo-deuteroporphyrin IX dimethyl ester $\mathbf{9 7}$ in $85 \%$ yield (Scheme 33) [87].

Mono-substituted alkenes under Heck conditions tend to produce the corresponding transalkenylporphyrins, particularly for large, sterically demanding substituents. For example, bromoporphyrins $\mathbf{9 9}$ gave the corresponding trans-alkenylporphyrins 100 in $>65 \%$ yields (the $c i s$-isomer was also observed when $\mathrm{R}=\mathrm{CN}$ ) under Heck conditions [123] and zinc(II)porphyrin 101 was produced in $86 \%$ yield under Stille conditions (Scheme 34) [125]. Monodi- and tetra-benzoporphyrins have been prepared via vicinal Heck couplings of di-, tetra-, 
and octa-bromoporphyrins followed by in situ $6 \pi$-electrocyclization and aromatization [145-147].

For example, dibenzoporphyrins 103 were prepared from tetrabromoporphyrins 102 in a single step, in 48-60\% yields (Scheme 35) [130]. Using a Stille cross-coupling reaction, porphyrin 104 was prepared in 60\% yield from porphyrin 78 (Scheme 36) [129].

Silylmethyl-substituted porphyrins, such as $\mathbf{1 0 5}$, are prepared by palladium(0)-catalyzed Kumada cross-coupling reactions of both meso- and $\beta$-bromoporphyrins with silylmethyl Grignard reagents [148]. For example, $\mathbf{1 0 5}$ was obtained from porphyrin $\mathbf{8 1}$ in $82 \%$ yield (Scheme 37). The silylmethylporphyrins can be converted into a variety of functional groups, including $\mathrm{CHO}, \mathrm{CH}_{2} \mathrm{OH}$, and $\mathrm{CH}_{2} \mathrm{~F}$.

\subsection{Nitration and Reactions of Nitroporphyrins}

The nitration of porphyrins can be achieved with nitric acid [149-153], nitrate salts (usually of copper, zinc or silver) [154], or with $\mathrm{N}_{2} \mathrm{O}_{4}$ [155-158] or nitrite ion [159-161] via the corresponding porphyrin $\pi$-cation radicals. The peripheral nitro substituents of porphyrins can be reduced to the corresponding amino derivatives using $\mathrm{SnCl}_{2} / \mathrm{HCl}$ [162], or with $\mathrm{NaBH}_{4}$ and $10 \% \mathrm{Pd} / \mathrm{C}$ in methanol [163], and $\beta$-aminoporphyrins have been shown to undergo acylation, diazotization and various reactions with carbonyl compounds [164-167].

Meso- and $\beta$-nitroporphyrins undergo ipso substitution of the nitro group to produce a variety of functionalized porphyrin macrocycles [106,168-172]. In addition, $\beta$ nitroporphyrins also undergo nucleophilic Michael-type additions at the adjacent $\beta$-position $[92,105,116,158,173-178]$ to produce functionalized porphyrins and chlorins. For example, $\beta$-nitroporphyrin 106 reacted with alkylmagnesium bromides or organolithium reagents to give alkylated porphyrins 107 [156] and with sodium methoxide or benzaldoxime to produce the corresponding 2-methoxy- or 2-hydroxy-porphyrin, respectively, via chlorin intermediates (Scheme 38). Several functionalized macrocycles have been obtained using this methodology, including 2-and 2,3-substituted porphyrins and chlorins. For example, trans-chlorins $\mathbf{1 0 9}$ were produced by reaction with active methylene compounds in the presence of base, via a fused cyclopropane chlorin [163]. $\beta$-Fused pyrroloporphyrins, such as $\mathbf{1 0 8}$, were also obtained from metallo-2-nitro-5,10,15,20tetraphenylporphyrin by reaction with a-isocyanoacetic esters in the presence of a base [179, 180]. On the other hand, 5-nitro-octaethylporphyrin 110 reacted by ipso-substitution of the nitro group in the presence of soft nucleophiles to produce porphyrins 111, whereas hard nucleophiles, such as methylmagnesium bromide and benzyl oxide gave the corresponding 15-substituted porphyrins (Scheme 39) [157], due to the higher stability of the intermediate, conferred by the 5-nitro group.

A $\beta$-nitro substituent on a porphyrin macrocycle, such as 106, directs electrophilic substitutions to the antipodal pyrrole ring, and this strategy has been used to regioselectively prepare 2,3-dibromo-meso-tetrarylporphyrins after reductive denitration [181]. 


\subsection{Formylation and Acylation Reactions}

The Vilsmeier formylation of porphyrins using $\mathrm{DMF} / \mathrm{POCl}_{3}$ followed by treatment with aqueous base introduces a formyl group at the meso- or the $\beta$-position of porphyrin macrocycles [182-185]. The use of a sterically hindered Vilsmeier reagent, such as that prepared from $N, N$-diisobutylformamide/ $/ \mathrm{POCl}_{3}$ favors substitution at the $\beta$-positions [186] whereas $N, N$-(dimethylamino)acrolein (3-DMA)/ $/ \mathrm{POCl}_{3}$ produces 2-formylvinylporphyrins in good yields [187, 188].

Other regioselective formylation methods use trimethyl orthoformate in TFA [189, 190], and via oxidation of 1,3-dithianylporphyrins [191, 192] or (2-

pyridyldimethylsilyl)methylporphyrins [193].

Formyl groups at the periphery of porphyrins can undergo a variety of reactions, including reductions, oxidations and nucleophilic additions, leading to a variety of functionalized macrocycles [194-206]. meso-Hydroxymethylporphyrins undergo dimerization under acidic conditions, producing dimers which upon dehydrogenation in acetic acid are transformed into trans-ethylene porphyrin dimers [207-210]. 1,2-Ethylene porphyrin dimers (cis- and trans-isomers), such as $\mathbf{1 1 3}$, are obtained directly by reductive coupling of metalloformylporphyrins (e.g. 112) using low-valent titanium complexes via a McMurry coupling reaction (Scheme 40) [89, 139, 140, 211-214]. Formyl-porphyrins also undergo Grignard and Wittig reactions [215-221] to produce a variety of cis- and trans-(2substituted-vinyl)porphyrins, which can be further functionalized (see also section below). The electrophilic acylation of metalloporphyrins can be achieved with acetic anhydride in the presence of Lewis acid catalysts, such as $\mathrm{SnCl}_{4}$, and occurs preferentially at the $\beta$ positions due to steric factors [222, 223]. The acetyl substituents of porphyrins can be reduced to vinyl groups with $\mathrm{NaBH}_{4}$ followed by dehydration using $p$-toluenesulfonic acid in 1,2-dichlorobenzene or alternatively by use of benzoyl chloride/DMF [224].

Alternatively, the enantioselective reduction of mono- and diacetyldeuteroporphyrin IX dimethyl ester can be accomplished with borane dimethyl sulfide in the presence of methyloxazaborolidine as the homochiral catalyst [225-227]. Acetylporphyrins also react under Vilsmeier conditions to produce 1-chloro-2-(formyl)vinyl derivatives, which can be converted to ethynyl-functionalized porphyrins by treatment with base [228, 229]. Under Wittig conditions zinc(II) acetylporphyrins react to produce isopropenylporphyrins [230, 231].

\subsection{Reactions with Nucleophiles}

Porphyrin macrocycles react with strong nucleophiles, such as Grignard and organolithium reagents preferentially at the meso-positions, with formation of meso-functionalized porphyrins as well as phlorins and porphodimethenes, or at the $\beta$-positions with formation of chlorins. The best known nucleophilic addition reactions occur on the $\pi$-cation radicals of metalloporphyrins, which can be obtained by chemical or electrochemical oxidation. The $\mathrm{Mg}$ (II) and $\mathrm{Zn}$ (II) complexes of porphyrins are usually employed since these display the lowest oxidation potentials and $\mathrm{I}_{2}$ (usually in the presence of $\mathrm{AgClO}_{4}$ or $\mathrm{AgPF}_{6}$ ), tris( $p$ bromophenyl)ammoniumyl hexachloroantimonate (TBAH) or $N$-chorobenzotriazole (CBT) are the oxidizing agents of choice. Although relatively stable in methanol, the $\pi$-cation 
radicals of metalloporphyrins react with a variety of soft nucleophiles to produce the corresponding meso- and $\beta$-substituted metalloporphyrins. For example, mesonitroporphyrins are obtained by treatment of metalloporphyrins with thallium(III) nitrate or cerium(IV) ammonium nitrate [232]. Pyridinium porphyrin salts are produced from the reaction of $\pi$-cation radicals with various pyridines [233-237]. Other nucleophiles $\left(\mathrm{CN}^{-}\right.$, $\mathrm{SCN}^{-}, \mathrm{Cl}^{-}, \mathrm{CH}_{3} \mathrm{CO}^{2-}$, imidazole, $\mathrm{PPh}_{3}$ ) were also shown to react with the $\pi$-cation radicals of porphyrins [202, 238]; dimeric and higher oligomeric porphyrin systems have been obtained from bidentate nucleophiles, such as bipyridine [239-241]. Chemical and electrochemical oxidative couplings of $\mathrm{Zn}$ (II) 5,15-diarylporphyrins lead to the formation of mesomeso and meso- $\beta$ linked porphyrin arrays, via nucleophilic attack of the $\pi$-cation radicals by neutral porphyrins $[161,242,243]$. Treatment of $\mathrm{Zn}(\mathrm{II})$ 5,15-diarylporphyrins with $\mathrm{AgPF}_{6}$ and $\mathrm{I}_{2}$ in the presence of pyridine led to regioselective meso-iodination [244]. The more electrophilic $\pi$-dications of porphyrins are formed under stronger oxidation conditions and react with, for example, methanol, preferentially at the meso-positions, leading to isoporphyrin derivatives [245, 246].

Reactions of organometallic reagents with both free-base and metalloporphyrins at unsubstituted meso-positions leads to the formation of intermediate phlorins and porphodimethenes, which are oxidized to the corresponding meso-substituted porphyrins [247, 248]. For example OEP 3 and several of its metal complexes produced the corresponding meso-functionalized porphyrins 115 in 40-90\% yields (Scheme 41). Di-, tri-, and tetra-meso-alkylated porphyrins can also be obtained via this methodology in overall yields of 20-40\%, by successive one equivalent additions of alkyllithium at low temperature, followed by hydrolysis and oxidation with DDQ [249]. Alkyl- and aryl-lithium agents showed meso-regioselectivity when 5,15-disubstituted porphyrins, such as $\mathbf{8 0}$ were used, producing the corresponding porphyrins 116 in 56-94\% yields (Scheme 42) [250-252].

meso-Tetrasubstituted porphyrins react with alkyllithiums to produce porphodimethenes, phlorins or chlorins [253]. Regioselective 15-meso-alkylation of zinc(II) 5formyloctaethylporphyrin $\mathbf{1 1 2}$ was accomplished by addition of methyl or ethyl magnesium bromide to give porphyrins 114, via a phlorin intermediate (Scheme 40) [254]; under the same conditions the free-base and $\mathrm{Ni}$ (II) derivatives react preferentially at the meso-formyl group with formation of the 1-hydroxylalkyl derivatives. Nucleophilic addition of hydroxide ion to $\mathrm{Au}$ (III) 5,10,15,20-tetraphenylporphyrin also occurs at a meso-position with formation of the corresponding hydroxyphlorin, whereas the $\mathrm{Cu}(\mathrm{II}), \mathrm{Pd}(\mathrm{II}), \mathrm{Cd}(\mathrm{II})$ and $\mathrm{Mn}(\mathrm{III})$ complexes of TPP were unreactive under the same conditions [255]. Reactions of organometallic reagents with iron(III) porphyrins occur preferentially at the metal center with formation of $\sigma$-bonded species [256, 257]; migration of the $\sigma$-bonded groups (alkyl, vinyl, aryl) from the metal ion to the nitrogen atom is induced by oxidation or by acid treatment [258-264].

\subsection{Oxidations and Reductions}

Porphyrins and metalloporphyrins (usually zinc complexes) can be oxidized to oxophlorins and oxochlorins, or to ring-opened products such as formyl- and benzoyl-biliverdins. 5Oxophlorins (such as 117) are formed by hydrolysis of meso-trifluoroacetoxyporphyrins, 
obtained from reaction of $\mathrm{Zn}$ (II) and $\mathrm{Mg}$ (II) $\beta$-substituted porphyrins with thallium(III) trifluoroacetate (TTFA) (Scheme 43) [265, 266].

Hydrogen peroxide in concentrated sulfuric acid [267, 268] and benzoyl peroxide can also be used for meso-oxidation [269, 270]. Reactions at the periphery of 5-oxophlorins occur preferentially at the electron-rich position-15 [271]. Neutral $\pi$-radicals of 5-oxophlorins are easily formed under mild conditions, and were shown to be stabilized by bulky 15substituents [272, 273]. Extensive meso-oxidation can lead to formation of di-, tri-, and tetraoxoporphyrins (the so-called xanthoporphyrinogens). Osmium tetroxide reacts selectively at the $\beta-\beta$ ' double bonds of porphyrins to produce the corresponding cisdihydroxychlorins; for example 118 is obtained from reaction of OEP 3 (Scheme 43) [274-277]. The $\beta$-substituted cis-dihydroxychlorins undergo pinacol-pinacolone rearrangement in perchloric acid or fuming sulfuric acid to give $\beta$-oxochlorins (for example 119 from 118). The regioselectively of the osmylation reaction and the migratory aptitudes of different peripheral substituents in the pinacol-pinacolone rearrangement have been investigated [278-282]. Metal-free oxochlorins such as 119 react further with osmium tetroxide regioselectively at the opposite pyrrole ring, whereas metal derivatives react preferentially at the adjacent $\beta$ - $\beta$ ' double bond producing the corresponding vic-dihydroxyand oxo-bacteriochlorins and isobacteriochlorins [283-287]. meso-Tetraarylporphyrins such as TPP react with benzoyl peroxide producing $\beta$-benzoyloxyporphyrins, which are converted into $\beta$-hydroxyporphyrins such as $\mathbf{1 2 0}$ by metalation, basic hydrolysis and demetalation (Scheme 44). Compound 120 can also be obtained from 2-nitro-meso-tetraphenylporphyrin by nucleophilic displacement of the nitro group with the sodium salt of $E$-benzaldoxime $[156,157]$. Oxidation of $\mathbf{1 2 0}$ to the 2,3-dioneporphyrin 121 can be accomplished under a variety of conditions, including $\mathrm{CrO}_{3}$ /acetic acid [288], photooxidation [157], and $\mathrm{SeO}_{2} /$ dioxane [157]; dioneporphyrin 121 reacts with aromatic $o$-diamines and with aromatic aldehydes in the presence of $\mathrm{NH}_{4} \mathrm{OAc} / \mathrm{AcOH}$ in $\mathrm{CHCl}_{3}$, producing a variety of pyrazinoand imidazole-porphyrin monomers and oligomeric systems [151, 289-292].

Open-chain oxygenated tetrapyrroles are obtained under several conditions, including $\mathrm{O}_{2}$ in the presence of ascorbic acid or hydrazine (the so-called coupled oxidation of iron porphyrins) [293, 294], using thallium(III) or cerium(IV) trifluoroacetate salts [232, 295], $\mathrm{N}_{2} \mathrm{O}_{4}$ or sodium nitrate and trifluoroacetic acid [296, 297], hydrogen peroxide [298], or meta-chloroperoxybenzoic acid (mCPBA) in pyridine [299], by reactions of metalloporphyrin $\pi$-cation radicals with nucleophiles [236], or from photo-oxidation by singlet oxygen, in the presence of light and molecular oxygen to give bilitrienones [300-308]. Porphyrins can also be reduced to dihydro- (chlorins, phlorins, porphodimethenes), tetrahydro- (isobacteriochlorins, bacteriochlorins, porphomethenes), and hexahydro-porphyrins (porphyrinogens). Reduction to cis-chlorins is normally accomplished with diimide (obtained from $p$-toluenesulfonylhydrazine) and potassium carbonate [309-312]. On the other hand, trans-chlorins can be obtained from the reduction of Fe(III) $\beta$ substituted porphyrins with sodium metal in isopentyl alcohol $[313,314]$. Porphyrins can also be photo-reduced by light in the presence of amines, ascorbic acid, and other compounds [315-320]. Regioselective photoreductions to cis-chlorins are achieved with ascorbic acid in the presence of diazabicyclo[2.2.2] octane (DABCO) as catalyst. 
Tetrahydroporphyrins are obtained by further reduction of chlorins under the conditions above. Metalloporphyrins often give isobacteriochlorins, whereas metal-free porphyrins preferentially give bacteriochlorins. Reduction to porphyrinogen can be accomplished by catalytic hydrogenation and this methodology has been used to prepare unsymmetrical macrocycles from symmetric porphyrins [321]. Metalloporphyrins can be reduced to $\pi$ anion radicals and $\pi$-dianions with, for example, sodium in THF or with sodium anthracenide [322-326]. Protonation and alkylation of porphyrin $\pi$-anions occurs preferentially at the meso-positions with formation of phlorins and porphodimethenes, which can rearrange to chlorins and be oxidized to porphyrins.

\section{Acknowledgments}

We acknowledge continuous research support from the National Institutes of Health, current grant number R01 CA132861.

\section{LIST OF ABBREVIATIONS}

\begin{tabular}{|c|c|}
\hline TPP & meso-tetraphenylporphyrin \\
\hline OEP & octaethylporphyrin \\
\hline DDQ & 2,3-dichloro-5,6-dicyanobenzoquinone \\
\hline TFA & trifluoroacetic acid \\
\hline TTFA & thallium(III) trifluoroacetate \\
\hline NBS & $N$-bromosuccinimide \\
\hline NCS & $N$-chlorosuccinimide \\
\hline dppf & bis(diphenylphosphino)ferrocene \\
\hline dba & dibenzylideneacetone \\
\hline DPEphos & (oxydi-2,1-phenylene)bis (diphenylphosphine) \\
\hline DMSO & dimethylsulfoxide \\
\hline DMF & dimethylformamide \\
\hline DME & dimethoxyethane \\
\hline AIBN & 2,2'-azobis(2-methylpropionitrile) \\
\hline Boc & tert-butoxycarbonyl \\
\hline THF & tetrahydrofuran \\
\hline BHT & butylated hydroxytoluene \\
\hline DBU & 1,8-diazabicyclo[5.4.0]undec-7-ene \\
\hline ТВАН & tris $(p$-bromophenyl)ammoniumyl hexachloroantimonate \\
\hline CBT & $N$-chorobenzotriazole \\
\hline DABCO & diazabicyclo[2.2.2] octane \\
\hline
\end{tabular}




\section{REFERENCES}

[1]. Fischer, H.; Orth, H. Die Chemie des Pyrrols. Vol. 1. Akademische Verlagsgesellschaft; Leipzig: 1934.

[2]. Fischer, H.; Orth, H. Die Chemie des Pyrrols. Vol. 2. Akademische Verlagsgesell-schaft; Leipzig: 1937. part 1

[3]. Fischer, H.; Stern, A. Die Chemie des Pyrrols. Vol. 2. Akademische Verlagsgesellschaft; Leipzig: 1940. part 2

[4]. Smith, KM., editor. Porphyrins and Metalloporphyrins. Elsevier; Amsterdam: 1975.

[5]. Kadish, KM.; Smith, KM.; Guilard, R., editors. The Porphyrin Handbook. Vol. 1-10. Academic Press; Boston: 1999. and Vols. 11-20, 2003

[6]. Kadish, KM.; Smith, KM.; Guilard, R., editors. Synthesis and Coordination Chemistry (Part 1). Vol. 2. World Scientific Press; Singapore: 2010. Handbook of Porphyrin Science.

[7]. Kadish, KM.; Smith, KM.; Guilard, R., editors. Synthetic Methodology. Vol. 3. World Scientific Press; Singapore: 2010. Handbook of Porphyrin Science.

[8]. Kadish, KM.; Smith, KM.; Guilard, R., editors. Synthesis and Structural Studies. Vol. 13. World Scientific Press: Singapore; 2011. Handbook of Porphyrin Science.

[9]. Kadish, KM.; Smith, KM.; Guilard, R., editors. Synthetic Developments (Part 1). Vol. 16. World Scientific Press; Singapore: 2012. Handbook of Porphyrin Science.

[10]. Kadish, KM.; Smith, KM.; Guilard, R., editors. Synthetic Developments (Part 2). Vol. 17. World Scientific Press; Singapore: 2012. >Handbook of Porphyrin Science.

[11]. Kadish, KM.; Smith, KM.; Guilard, R., editors. Synthesis. Vol. 23. World Scientific Press; Singapore: 2012. Handbook of Porphyrin Science.

[12]. Sessler, JL.; Weghorn, SJ. Expanded, contracted and isomeric porphyrins. Pergamon Press; Oxford: 1997.

[13]. Taniguchi, M.; Lindsey, JS. Enumeration of isomers of substituted tetrapyrrole macrocycles: from classical problems in biology to modern combinatorial libraries. In: Kadish, KM.; Smith, KM.; Guilard, R., editors. Handbook of Porphyrin Science. Vol. 23. World Scientific Press; Singapore: 2012. p. 3-80.

[14]. Smith, KM. Strategies for the synthesis of octaalkylporphyrin systems. In: Kadish, KM.; Smith, KM.; Guilard, R., editors. The Porphyrin Handbook. Vol. 1. Academic Press; Boston: 1999. p. $1-43$.

[15]. Jackson, AH.; Smith, KM. Total synthesis of pyrrole pigments. In: ApSimon, JW., editor. Total Synthesis of Natural Products. Vol. 1. Wiley; New York: 1973. p. 143-278.and 1984; Vol. 6, pp 237-280.

[16]. Baltazzi E, Krimen LI. Recent advances in chemistry of pyrrole. Chem. Rev. 1963; 63:511-556.

[17]. Gossauer, A. Die Chemie der Pyrrole. Springer Verlag; Berlin: 1974.

[18]. Rothemund P. Formation of porphyrins from pyrrole and aldehydes. J. Am.Chem. Soc. 1935; 57:2010-2011.

[19]. Rothemund P, Menotti AR. The synthesis of $a, \beta, \gamma, \delta$-tetraphenylporphine. J. Am. Chem. Soc. $1941 ; 63: 267-270$.

[20]. Adler AD, Longo FR, Finarelli JD, Goldmacher J, Assour J, Korsakoff L. A simplified synthesis for meso-tetraphenylporphine. J. Org. Chem. 1967; 32:476-477.

[21]. Lindsey JS, Schreiman IC, Hsu HC, Kearney PC, Marguerettaz AM. Rothemund and AdlerLongo reactions revisited: synthesis of tetra-phenylporphyrins under equilibrium conditions. J. Org. Chem. 1987; 52:827-836.

[22]. Lindsey, JS. The Porphyrin Handbook. Kadish, KM.; Smith, KM.; Guilard, R., editors. Vol. 1. Academic Press; Boston: 1999. p. 45-118.

[23]. Badger GM, Jones RA, Laslett RL. Porphyrins. VII. The synthesis of porphyrins by the Rothemund reaction. Aust. J. Chem. 1964; 17:1028-1035.

[24]. Barnett GH, Hudson MF, Smith KM. Concerning meso-tetraphenylporphyrin purification. J. Chem. Soc. Perkin Trans., 1. 1975:1401-1403. 
[25]. Sessler JL, Mozaffari A, Johnson MR. 3,4-Diethylpyrrole and 2,3,7,8,12,13,17,18octaethylporphyrin. Org. Synth. 1991; 70:68-77.

[26]. Ono M, Lattmann R, Imomota K, Lehmann C, Früh T, Eschenmoser A. Monopyrrole precursors for the synthesis of uroporphyrinogenoctanitrile. Croat. Chem. Acta. 1985; 58:627-638.

[27]. Schreiber J, Maag H, Hashimoto N, Eschenmoser A. Dimethyl(methylene)ammonium iodide. Angew. Chem. Int. Ed. Engl. 1971; 10:330-331.

[28]. Whitlock HW, Hanauer R. Octaethylporphyrin. J. Org. Chem. 1968; 33:2169-2171.

[29]. Eisner U, Lichtarowicz A, Linstead RP. Chlorophylls and related compounds. Part VI. The synthesis of octaethylchlorin. J. Chem. Soc. 1957:733-739.

[30]. Inhoffen HH, Fuhrhop J-H, Voigt H, Brockmann H Jr. Formylierung der mesoKohlenstoffeatome von alkylsubstituierten porphyrinen. Liebigs Ann. Chem. 1966; 695:133-145.

[31]. Siedel W, Winkler F. Oxydation von pyrrolderivaten mit bleitetraacetat. Liebigs Ann. Chem. 1943; 554:162-201.

[32]. a Barton DHR, Zard SZ. A new synthesis of pyrroles from nitroalkenes. J. Chem. Soc. Chem. Commun. 1985:1098-1099.b Barton DHR, Kervagoret J, Zard SZ. A useful synthesis of pyrroles from nitroolefins. Tetrahedron. 1990; 46:7587-7598.

[33]. Ono N, Kawamura H, Bougauchi M, Maruyama K. Porphyrin synthesis from nitrocompounds. Tetrahedron. 1990; 46:7483-7496.

[34]. Aoyagi K, Haga T, Toi H, Aoyama Y, Mizutani T, Ogoshi H. Electron deficient porphyrins. III. Facile syntheses of perfluoroalkylporphyrins including water soluble porphyrin. Bull. Chem. Soc. Jpn. 1997; 70:937-943.

[35]. Neya S, Quan J, Hoshino T, Hata M, Funasaki N. Convenient synthesis of porphine from btetra(tert-butyl)porphyrin. Tetrahedron Lett. 2004; 45:8629-8630.

[36]. Mauzerall D. The thermodynamic stability of porphyrinogens. J. Am. Chem. Soc. 1960; 82:2601-2603.

[37]. Nguyen LT, Smith KM. Syntheses of Type-I porphyrins via monopyrrole tetramerization. Tetrahedron Lett. 1996; 37:7177-7180.

[38]. Nguyen LT, Senge MO, Smith KM. One-pot synthesis of regiochemically pure porphyrins from two different pyrroles. Tetrahedron Lett. 1994; 35:7581-7584.

[39]. Arsenault GP, Bullock E, MacDonald SF. Pyrromethanes and porphyrins therefrom. J. Am. Chem. Soc. 1960; 82:4384-4389.

[40]. a Woodeard RB. Totalsynthese des Chlorophylls. Angew. Chem. 1960; 72:651-662.b Woodward RB, Ayer WA, Beaton JM, Bickelhaupt F, Bonnett R, Buchschacher P, Closs GL, Dutler H, Hannah J, Hauck FP, Ito S, Langemann A, Le Goff E, Leimgruber W, Lwowski W, Sauer J, Valenta Z, Volz H. The total synthesis of chlorophyll a. Tetrahedron. 1990; 46:7599-7659.

[41]. Fischer, H.; Orth, H. Die Chemie des Pyrrols. Vol. 1. Akademische Verlagsgesell-schaft; Leipzig: 1934. p. 333

[42]. Mironov AF, Ovsepyan TR, Evstigneeva RP, Preobrazenskii NA. Synthetic studies in the dipyrrylmethane series. Synthesis of 4,4'-dimethyl- 3,3'-bis $(\beta$ carbomethoxyethyl)dipyrrylmethane. Zh. Obshch. Khim. 1965; 35:324-328.

[43]. Cavaleiro JAS, Gonsalves A.M.d'A.R. Kenner GW, Smith KM. Synthesis of pyrromethanes and a tripyrrane. J. Chem. Soc. Perkin Trans. 1. 1973:2471-2478.

[44]. Jackson AH, Pandey RK, Rao KRN, Roberts E. Reactions on solid supports, Part II: a convenient method for synthesis of pyrromethanes using a Montmorillonite clay as catalyst. Tetrahedron Lett. 1985; 26:793-796.

[45]. Freeman BA, Smith KM. Alternative syntheses of pyrromethanes and porphyrins using acidmodified Montmorillonite K-10 Clay. Synth. Commun. 1999; 29:1843-1855.

[46]. Cavaleiro JAS, Gonsalves A.M.d'A.R. Kenner GW, Smith KM. Total synthesis of deuteriated derivatives of drotoporphyrin-IX for NMR studies of haemoproteins. J. Chem. Soc. Perkin Trans. 1. 1974:1771-1781.

[47]. Cavaleiro JAS, Kenner GW, Smith KM. Biosynthesis of protoporphyrin-IX from coproporphyrinogen-III. J. Chem. Soc. Perkin Trans. 1974; 1:1188-1194. [PubMed: 4212292] 
[48]. Martin P, Mueller M, Flubacher D, Boudier A, Blaser H-U, Spielvogel D. Total synthesis of hematoporphyrin and protoporphyrin: A conceptually new approach. Org. Pro. Res. Dev. 2010; 14:799-804.

[49]. Martin P, Mueller M, Flubacher D, Boudier A, Blaser H-U, Spielvogel D. Total synthesis of hematoporphyrin and protoporphyrin: A conceptually new approach. Chimia. 2013; 67:204-206. [PubMed: 23967689]

[50]. a Sessler JL, Lynch V, Johnson MR. Synthesis and crystal structure of a novel tripyrranecontaining porphyrinogen-like macrocycle. J. Org. Chem. 1987; 52:4394-4397.b Sessler JL, Cyr MJ, Lynch V. Synthetic and structural studies of sapphyrin, a 22-p-electron pentapyrrolic "expanded porphyrin". J. Am. Chem. Soc. 1990; 112:2810-2813.

[51]. a Boudif A, Momenteau M. Synthesis of a porphyrin-2,3-diacrylic acid using a new ' $3+1$ ' type procedure. J. Chem. Soc. Chem. Commun. 1994:2069-2070.b Boudif A, Momenteau M. A new convergent method for porphyrin synthesis based on a ' $3+1$ ' condensation. J. Chem. Soc. Perkin Trans. 1. 1996:1235-1242.

[52]. a Lash TD, Novak BH. Tetraphenanthro[9,10-b:9,10-g:9,10-l:9,10-q]-porphyrin, a new highly conjugated porphyrin system. Angew. Chem. Int. Ed. Engl. 1995; 34:683-685.b Lash TD, Novak BH. New highly conjugated porphyrin chromophores: Synthesis of mono- and diphenanthroporphyrins. Tetrahedron Lett. 1995; 36:4381-4284.c Lin Y, Lash TD. Porphyrin synthesis by the " $3+1$ " methodology: A superior approach for the preparation of porphyrins with fused 9,10-phenanthroline subunits. Tetrahedron Lett. 1995; 36:9441-9444.d Lash TD. Porphyrin synthesis by the " $3+1$ " approach: new applications for an old methodology. Chem. Eur. J. 1996; 2:1197-1200.e Lash TD. Porphyrins with exocyclic rings. Part 9. Synthesis of porphyrins by the ' $3+1$ ' approach. J. Porphyrins Phthalocyanines. 1997; 1:29-144.

[53]. Sessler JL, Genge JW, Urbach A, Sanson P. A '3+1' approach to monofunctionalized alkyl porphyrins. Synlett. 1996; 2:187-188.

[54]. Nguyen LT, Senge MO, Smith KM. Simple methodology for syntheses of porphyrins possessing multiple peripheral substituents with an element of symmetry. J. Org. Chem. 1996; 61:998-1003.

[55]. Johnson AW, Kay IT. The formation of porphyrins by the cyclisation of bilenes. J. Chem. Soc. C. 1961:2418-2423.

[56]. Smith, KM. Cyclizations of a,c-biladiene salts to give porphyrins and their derivatives. In: Kadish, KM.; Smith, KM.; Guilard, R., editors. The Porphyrin Handbook. Vol. 1. Academic Press; Boston: 1999. p. 119-148.

[57]. Smith KM, Kehres LA. Syntheses of methyl devinylporphyrins related to protoporphyrin-IX. Initial studies on the mechanism of the copper(II) catalyzed cyclizations of 1',8'-dimethyl-a,cbiladienes. J. Chem. Soc. Perkin Trans. 1. 1983:2329-2335.

[58]. Smith KM, Minnetian OM. Novel porphyrins from copper(II) mediated cyclizations of 1', 8'dimethyl-a,c-biladiene salts: Mechanism of the cyclization reaction. J. Org. Chem. 1985; 50:2073-2080.

[59]. Smith KM, Minnetian OM. Cyclizations of 1',8'-dimethyl-a,c-biladiene salts to give porphyrins: A study with various oxidizing agents. J. Chem. Soc. Perkin Trans. 1. 1986:277-280.

[60]. Jeyakumar D, Snow KM, Smith KM. Electrosynthesis of porphyrins from a,c-biladienes. J. Am. Chem. Soc. 1988; 110:8562-8564.

[61]. Swanson KL, Snow KM, Jeyakumar D, Smith KM. Tetrapyrrole products from electrochemical cyclization of 1',8'-disubstituted-a,c-biladiene salts. Tetrahedron. 1991; 47:685-696.

[62]. Liddell PA, Gerzevske KR, Lin JJ, Olmstead MM, Smith KM. Novel macrocycles from metalcatalyzed oxidative cyclizations of a,c-biladiene salts. J. Org. Chem. 1993; 58:6681-6691.

[63]. Gerzevske KR, Lin JJ, Smith KM. Kinetic vs. thermodynamic product distributions of macrocyclic tetrapyrrole cyclization products from 1,19- disubstituted a,c-biladiene salts. Heterocycles. 1994; 37:207-212.

[64]. Lin JJ, Gerzevske KR, Liddell PA, Senge MO, Olmstead MM, Khoury RG, Weeth BE, Tsao SA, Smith KM. Metal-catalyzed oxidative cyclizations of a,c-biladiene salts bearing 1- and/or 19arylmethyl substituents: Macrocyclic products and their chemistry. J. Org. Chem. 1997; 62:4266-4276. [PubMed: 11671746] 
[65]. Lin JJ, Holmes RT, Smith KM. Oxidative cyclization of a,c-biladienes: The role of the metal ion. J. Porphyrins Phthalocyanines. 1998; 2:363-368.

[66]. Boschi T, Paolesse R, Tagliatesta P. Transition-metal-catalyzed cyclization of $[a, c]$ biladiene salts as an efficient route to the synthesis of alkyl porphyrins. Inorg. Chim. Acta. 1990; 168:8387.

[67]. Almeida JAPB, Kenner GW, Rimmer J, Smith KM. A general stepwise synthesis of unsymmetrically substituted porphyrins. Tetrahedron. 1976; 32:1793-1799.

[68]. Smith KM, Craig GW. Porphyrin synthesis through tripyrrins: An alternate approach. J. Org. Chem. 1983; 48:4302-4306.

[69]. Naruta Y, Tani F, Maruyama K. Meso-perfluorination of porphyrins with $N$-fluoropyridinium triflate. Tetrahedron Lett. 1992; 33:1069-1072.

[70]. Andrews LE, Bonnett R, Kozyrev AN, Appelman EH. meso-Reactivity of porphyrins and related compounds. Part 10. Direct fluorination of octaethylporphyrin with caesium fluoroxysulphate. J. Chem. Soc. Perkin Trans. 1. 1988:1735-1738.

[71]. Tsuchiya S, Seno M. Novel synthetic method of phenol from benzene catalysed by perfluorinated hemin. Chem. Lett. 1989:263-266.

[72]. Wijesekera T, Matsumono A, Dolphin D, Lexa D. Perchlorinated and highly chlorinated mesotetraphenylporphyrins. Angew. Chem. Int. Ed. Engl. 1990; 29:1028-1030.

[73]. Gonsalves, A.M.d'A.R.; Johnstone, RAW.; Pereira, MM.; Shaw, J.; Sobral, JFN. Metal-assisted reactions. Part 22. Synthesis of perhalogenated prophyrins and their use as oxidation catalysts. Tetrahedron Lett. 1991; 32:1355-1358.

[74]. Chorghade MS, Dolphin D, Dupré D, Hill DR, Lee EC, Wijesekera TP. Improved protocols for the synthesis and halogenation of sterically hindered metalloporphyrins. Synthesis. 1996:1320 1324.

[75]. Wijesekera T, Dupré D, Cader MR, Dolphin D. Porphyrins bearing halogens at the meso-phenyl and beta-pyrrolic positions: Synthesis and spectral properties. Bull. Soc. Chim. Fr. 1996; 133:765-765.

[76]. Vicente MGH, Smith KM. Functionalizations of the alkyl substituents in octa-alkylporphyrins. Tetrahedron. 1991:6887-6894.

[77]. Hoffmann P, Robert A, Meunier B. Preparation and catalytic activities of the manganese and iron derivatives of Br8TMP and C112TMP, two robust porphyrin ligands obtained by halogenation of tetramesitylporphyrin. Bull. Soc. Chim. Fr. 1992; 129:85-97.

[78]. Bonnett R, Gale IAD, Stephenson GF. The meso-reactivity of porphyrins and related compounds. Part II. Halogenation. J. Chem. Soc. C. 1966:1600-1604.

[79]. Ali H, van Lier JE. Phenylselenyl halides: efficient reagents for the selective halogenation and nitration of porphyrins. Tetrahedron Lett. 1991:5015-5018.

[80]. Hoffmann P, Labat G, Robert A, Meunier B. Highly selective bromination of tetramesitylporphyrin: an easy access to robust metalloporphyrins, M-Br8TMP and MBr8TMPS. Examples of application in catalytic oxygenation and oxidation reactions. Tetrahedron Lett. 1990; 31:1991-1994.

[81]. DiMagno SG, Lin VS-Y, Therien MJ. Facile elaboration of porphyrins via metal-mediated crosscoupling. J. Org. Chem. 1993; 58:5983-5993.

[82]. Bonnett R, Campion-Smith IH, Kozyrev AN, Mironov AF. J. Chem. Res. (S). 1990:13814.Bonnett R, Campion-Smith IH, Kozyrev AN, Mironov AF. J. Chem. Res. (M). 1990:10151026.

[83]. Tagliatesta P, Li J, Autret M, Van Caemelbecke E, Villard A, D’Souza F, Kadish KM. Electrochemistry and spectral characterization of oxidized and reduced (TPPBrx) $\mathrm{FeCl}$ where TPPBrx is the dianion of $\beta$-pyrrole brominated tetraphenylporphyrin and $\mathrm{x}$ varies from 0 to 8 . Inorg. Chem. 1996; 35:5570-5576. [PubMed: 11666748]

[84]. Shea KM, Jaquinod L, Khoury RG, Smith KM. Dodecasubstituted chlorins (dihydroporphyrins). Chem. Commun. 1998:759-760.

[85]. Bhyrappa P, Krishnan V. Octabromotetraphenylporphyrin and its metal derivatives: electronic structure and electrochemical properties. Inorg. Chem. 1991; 30:239-245. 
[86]. Hariprasad G, Dahal S, Maiya BG. meso-Substituted octabromoporphyrins: synthesis, spectroscopy, electrochemistry and electronic structure. J. Chem. Soc. Dalton Trans. 1996:34293436.

[87]. Minnetian OM, Morris IK, Snow KM, Smith KM. New syntheses and reactions of some halogenated porphyrins. J. Org. Chem. 1989; 54:5567-5574.

[88]. Crossley MJ, Burn PL, Chew SS, Cuttance FB. Newsom. I.A. Regiospecific introduction of four substituents to porphyrin systems at antipodal pyrrolenic positions. J. Chem. Soc., Chem. Commun. 1991:1564-1566.

[89]. Spyroulias GA, Despotopoulos AP, Raptopoulous CP, Terzis A, Montauzon D, Poilblanc R, Coutsolelos AG. Comparative study of structure-properties relationship for novel betahalogenated lanthanide porphyrins and their nickel and free bases precursors, as a function of number and nature of halogens atoms. Inorg. Chem. 2002; 41:2648-2659. [PubMed: 12005488]

[90]. Boyle RW, Johnson CK, Dolphin D. Iodination and Heck alkynylation of 5,15diphenylporphyrin. A convenient entry to asymmetrically meso-substituted porphyrins. J. Chem. Soc. Chem. Commun. 1995:527-528.

[91]. Shanmugathasan S, Johnson CK, Edwards C, Matthews EK, Dolphin D, Boyle RW. Regioselective halogenation and palladium-catalysed couplings on 5,15-diphenylporphyrin. J. Porphyrins Phthalocyanines. 2000; 4:228-232.

[92]. Monteiro CJP, Pereira MM, Vicente MGH, Arnaut LG. Photophysical properties of unsymmetric meso-substituted porphyrins synthesized via the Suzuki coupling reaction. Tetrahedron. 2012; 68:8783-8788.

[93]. Vicente MGH, Smith KM. Functionalization of alkyl substituents in octaalkylporphyrins. Synlett. 1990:579-581.

[94]. Callot HJ. Bromination of meso-tetraphenylporphine. Structure and reactivity of products. Tetrahedron Lett. 1973; 50:4987-4990.

[95]. Callot HJ. Bomination of m-tetraphenylporphine. Preparation of alkyl derivatives and polycyanoporphines. Bull. Soc. Chim. Fr. 1974:1492-1496.

[96]. Arnold DP, Bott RC, Eldridge H, Elms FM, Smith G, Zojaji M. Functionalization of 5,15diphenylporphyrin: preparation and x-ray crystal structures of meso nitro, bromo, and trimethylsilylethynyl derivatives. Aust. J. Chem. 1997; 50:495-503.

[97]. Gauler R, Risch N. Synthesis of carbon-carbon linked porphyrinoligomers by utilization of Hecktype coupling of natural tetrapyrroles. Tetrahedron Lett. 1997; 38:223-224.

[98]. Shultz DA, Gwaltney KP, Lee H. A modified procedure for Sonogashira couplings: synthesis and characterization of a bisporphyrin, 1,1-bis[zinc(II) $5^{\circ}$-ethynyl-10`,15', 20`trimesitylporphyrinyl]methylenecyclohexane. J. Org. Chem. 1998; 63:4034-4038.

[99]. Vicente MGH, Jaquinod L, Smith KM. Oligomeric porphyrin arrays. Chem. Commun. 1999:1771-1782.

[100]. Setsune J-I. Palladium chemistry in recent porphyrin research. J. Porphyrins Phthalocyanines. 2004; 8:93-102.

[101]. Fazekas M, Pintea M, Senge MO, Zawadzka M. Synthetic strategies and porphyrin building blocks for unsymmetrical multichromophores. Tetrahedron Lett. 2008; 49:2236-2239.

[102]. Esdaile LJ, Senge MO, Arnold DP. New palladium catalysed reactions of bromoporphyrins: synthesis and crystal structures of nickel(II) complexes of primary 5-aminoporphyrin, 5,5'bis(porphyrinyl) secondary amine, and 5-hydroxyporphyrin. Chem. Commun. 2006:4192-4194.

[103]. Gao G-Y, Ruppel JV, Fields KB, Xu X, Chen Y, Zhang XP. Synthesis of diporphyrins via palladium-catalyzed C-O bond formation: effective access to chiral diporphyrins. J. Org. Chem. 2008; 73:4855-4858. [PubMed: 18540646]

[104]. Bringmann G, Gotz DCG, Gulder TAM, Gehrke TH, Bruhn T, Kupfer T, Radacki K, Braunschweig H, Heckmann A, Lambert C. Axially chiral $\beta, \beta^{\prime}$-bisporphyrins: synthesis and configurational stability tuned by the central metals. J. Am. Chem. Soc. 2008; 130:17812-17825. [PubMed: 19055342]

[105]. Aratani N, Osuka A. Synthesis of meso-meso linked hybrid porphyrin arrays by Pd-catalyzed cross-coupling reaction. Org. Lett. 2001; 3:4213-4216. [PubMed: 11784180] 
[106]. Peng X, Nakamura Y, Aratani N, Kim D, Osuka A. 1,4-Phenylene-bridged meso-meso linked diporphyrin array. Tetrahedron Lett. 2004; 45:4981-4984.

[107]. Frampton MJ, Akdas H, Cowley AR, Rogers JE, Slagle JE, Fleitz PA, Drobizhev M, Rebane A, Anderson HL. Synthesis, crystal structure and nonlinear optical behavior of $\beta$-unsubstituted meso-meso E-vinylene-linked porphyrin dimers. Org. Lett. 2005; 7:5365-5368. [PubMed: 16288507]

[108]. Tokuji S, Yurino T, Aratani N, Shinokubo H, Osuka A. Palladium-catalyzed dimerization of meso-bromoporphyrins: highly regioselective meso- $\beta$ coupling via unprecedented remote $\mathrm{C}-\mathrm{H}$ bond cleavage. Chem. Eur. J. 2009; 15:12208-12211. [PubMed: 19834950]

[109]. Chan KS, Zhou X, Au MT, Tam CY. Synthesis of beta-aryl substituted porphyrins by palladium catalyzed Suzuki cross-coupling reactions. Tetrahedron. 1995; 51:3129-3136.

[110]. Zhou X, Tse MK, Wan TSM, Chan KS. Synthesis of Bmono-, tetra-, and octasubstituted sterically bulky porphyrins via Suzuki cross coupling. J. Org. Chem. 1996; 61:3590-3593. [PubMed: 11667202]

[111]. Muzzi CM, Medforth CJ, Voss L, Cancilla M, Lebrilla C, Ma J-G, Shelnutt JA, Smith KM. Novel dodecaarylporphyrin: synthesis and dynamic properties. Tetrahedron Lett. 1999; 40:61596162.

[112]. Hao EH, Fronczek FR, Vicente MGH. Carborane functionalized pyrroles and porphyrins via the Suzuki cross-coupling reaction. Chem. Commun. 2006:4900-4902.

[113]. Locos OB, Dahms K, Senge MO. Allenylporphyrins: a new motif on the porphyrin periphery. Tetrahedron Lett. 2009; 50:2566-2569.

[114]. Chen Y, Zhang XP. Facile and efficient synthesis of meso-arylamino- and alkylaminosubstituted porphyrins via palladium-catalyzed amination. J. Org. Chem.

[115]. Gao G-Y, Colvin AJ, Chen Y, Zhang XP. Versatile synthesis of meso-aryloxy- and alkoxysubstituted porphyrins via palladium-catalyzed C-O cross-coupling reactions. Org. Lett. 2003; 5:3261-3264. [PubMed: 12943402]

[116]. Takanami T, Hayashi M, Hino F, Suda K. Palladium-catalyzed meso-amination and amidation of porphyrins: marked acceleration with the Ni(II) central metal ion. Tetrahedron Lett. 2003; 44:7353-7357.

[117]. Esdaile LJ, McMurtrie JC, Turner P, Arnold DP. Modified porphyrinoids from carbazates and hydrazones and the first crystal structure of a diiminoporphodimethene. Tetrahedron Lett. 2005; 46:6931-6935.

[118]. Gao G-Y, Chen Y, Zhang XP. General synthesis of meso-amidoporphyrins via palladiumcatalyzed amidation. Org. Lett. 2004; 6:1837-1840. [PubMed: 15151427]

[119]. Gao G-Y, Colvin AJ, Chen Y, Zhang XP. Versatile synthesis of meso-aryloxy- and alkoxysubstituted porphyrins via palladium-catalyzed C-O cross-coupling reactions. Org. Lett. 2003; 5:3261-3264. [PubMed: 12943402]

[120]. Chen Y, Gao GY, Zhang XP. Palladium-mediated synthesis of novel meso-chiral porphyrins: cobalt-catalyzed cyclopropanation. Tetrahedron Lett. 2005; 46:4965-4969.

[121]. Gao G-Y, Colvin AJ, Chen Y, Zhang XP. Synthesis of meso-arylsulfanyl- and alkylsulfanylsubstituted porphyrins via palladium-mediated C-S bond formation. J. Org. Chem. 2004; 69:8886-8892. [PubMed: 15575770]

[122]. Atefi F, McMurtrie JC, Turner P, Duriska M, Arnold DP. meso-Porphyrinylphosphine oxides: mono- and bidentate ligands for supramolecular chemistry and the crystal structures of monomeric $\{[10,20$-diphenylporphyrinatonickel(II)-5,15-diyl]-bis-[P(O) $\mathrm{Ph} 2]\}$ and polymeric self-coordinated $\{[10,20$-diphenylporphyrinatozinc(II)-5,15-diyl]-bis-[P(O)Ph2]\}. Inorg. Chem. 2006; 45:6479-6489. [PubMed: 16878962]

[123]. Matano Y, Matsumoto K, Nakao Y, Uno H, Sakaki S, Imahori H. Regioselective $\beta$-metalation of meso-phosphanylporphyrins. Structure and optical properties of porphyrin dimers linked by peripherally fused phosphametallacycles. J. Am. Chem. Soc. 2008; 130:4588-4589. [PubMed: 18345675]

[124]. Liu C, Chen QY. General and efficient synthesis of meso- and $\beta$-perfluoroalkylated porphyrins via Pd-catalyzed cross-coupling reaction. Synlett. 2005:1306-1310. 
[125]. Horn S, Cundell B, Senge MO. Exploration of the reaction of potassium organotrifluoroborates with porphyrins. Tetrahedron Lett. 2009; 50:2562-2565.

[126]. Hyslop AG, Kellett MA, Iovine PM, Therien MJ. Suzuki porphyrins: New synthons for the fabrication of porphyrin-containing su- pramolecular assemblies. J. Am. Chem. Soc. 1998120:12676-12677.

[127]. Iovine PM, Kellett MA, Redmore NP, Therien MJ. Syntheses and 1H NMR spectroscopy of rigid, cofacially aligned, porphyrin-bridge-quinone systems in which the interplanar separations between the porphyrin, aromatic bridge, and quinone are less than the sum of their respective van der Waals radii. J. Am. Chem. Soc. 2000; 122:8717-8727.

[128]. Chng LL, Chang CJ, Nocera DG. meso-Tetraaryl cofacial bisporphyrins delivered by Suzuki cross-coupling. J. Org. Chem. 2003; 68:4075-4078. [PubMed: 12737594]

[129]. Chang LL, Chang CJ, Nocera DG. Catalytic O-O activation chemistry mediated by iron hangman porphyrins with a wide range of proton-donating abilities. Org. Lett. 2003; 5:24212424. [PubMed: 12841745]

[130]. Chang CJ, Chang LL, Nocera DG. Proton-coupled O-O activation on a redox platform bearing a hydrogen-bonding scaffold. J. Am. Chem. Soc. 2003; 125:1866-1876. [PubMed: 12580614]

[131]. Zhang T-G, Zhao Y, Asselberghs I, Persoons A, Clays K, Therien MJ. Design, synthesis, linear, and nonlinear optical properties of conjugated (porphinato)zinc(II)-based donor-acceptor chromophores featuring nitrothiophenyl and nitrooligothiophenyl electron-accepting moieties. J. Am. Chem. Soc. 2005; 127:9710-9720. [PubMed: 15998075]

[132]. Sazanovich IV, Balakumar A, Muthukumaran K, Hindin E, Kirmaier C, Diers JR, Lindsey JS, Bocian DF, Holten D. Excited-state energy-transfer dynamics of self-assembled imine-linked porphyrin dyads. Inorg. Chem. 2003; 42:6616-6628. [PubMed: 14552614]

[133]. Ali H, van Lier JE. Synthesis of $\beta$-substituted porphyrins using palladium catalysed reactions. Tetrahedron. 1994; 50:11933-11944.

[134]. Lee C-W, Lu H-P, Lan C-M, Huang Y-L, Liang Y-R, Yen W-N, Liu Y-C, Lin Y-S, Diau EWG, Yeh C-Y. Novel zinc porphyrin sensitizers for dye-sensitized solar cells: synthesis and spectral, electrochemical, and photovoltaic properties. Chem. Eur. J. 2009; 15:1403-1412. [PubMed: 19097125]

[135]. Poon KW, Liu W, Chan P-K, Yang Q, Chan T-WD, Mak TCW, Ng DKP. Tetrapyrrole derivatives substituted with ferrocenylethynyl moieties. Synthesis and electrochemical studies. J. Org. Chem. 2001; 66:1553-1559. [PubMed: 11262097]

[136]. Huang X, Zhu C, Zhang S, Li W, Guo Y, Zhan X, Liu Y, Bo Z. Porphyrin-dithienothiophene $\pi$ conjugated copolymers: synthesis and their applications in field-effect transistors and solar cells. Macromolecules. 2008; 41:6895-6902.

[137]. Jiblaoui A, Baudequin C, Chaleix V, Ducourthial G, Louradour F, Ramondenc Y, Sol V, LeroyLhez S. An easy one-pot desilylation/copper-free Sonogashira cross-coupling reaction assisted by tetrabutylammonium fluoride (TBAF): synthesis of highly $\pi$-conjugated porphyrins. Tetrahedron. 2013; 69:5098-5103.

[138]. Yu Z, Ptaszek M. Multifunctional bacteriochlorins from selective palladium-coupling reactions. Org. Lett. 2012; 14:3708-3711. [PubMed: 22783931]

[139]. Sahoo AK, Mori S, Shinokubo H, Osuka A. Facile peripheral functionalization of porphyrins by Pd-catalyzed [3+2] annulation with alkynes. Angew. Chem. Int. Ed. 2006; 45:7972-7975.

[140]. Ishizuka T, Yamasaki H, Osuka A, Furuta H. Syntheses of aryl- and arylethynyl-substituted Nconfused porphyrins. Tetrahedron. 2007; 63:5137-5147.

[141]. Locos OB, Arnold DP. The Heck reaction for porphyrin functionalisation: synthesis of mesoalkenyl monoporphyrins and palladium-catalysed formation of unprecedented meso- $\beta$ ethenelinked diporphyrins. Org. Biomol. Chem. 2006; 4:902-916. [PubMed: 16493475]

[142]. Odobel F, Suzenet F, Blart E, Quintard J-P. An efficient synthetic approach to highly conjugated porphyrin-based assemblies containing a bipyridine moiety. Org. Lett. 2000; 2:131133. [PubMed: 10814264]

[143]. Bhyrappa P, Velkannan V. $\beta$-Tetrakis(2-thienyl)-meso-tetraphenylporphyrins: Synthesis, structural and electrochemical redox properties. Inorg. Chim. Acta. 2012; 387:64-73. 
[144]. Smith MJ, Clegg W, Nguyen KA, Rogers JE, Pachter R, Fleitz PS, Anderson HL. Synthesis and crystal structure of a push-pull quinoidal porphyrin: a nanoporous framework assembled from cyclic trimer aggregates. Chem. Commun. 2005:2433-2435.

[145]. Deshpande R, Jiang L, Schmidt G, Rakovan J, Wang X, Wheeler K, Wang H. A concise approach to the synthesis of opp-dibenzoporphyrins through the Heck reaction. Org. Lett. 2009; 11:4251-4253. [PubMed: 19775180]

[146]. Jiang L, Engle JT, Sirk L, Hartley CS, Ziegler CJ, Wang H. Triphenylene-fused porphyrins. Org. Lett. 2011; 13:3020-3023. [PubMed: 21604789]

[147]. Jiang L, Zaenglein RA, Engle JT, Mittal C, Hartley CS, Ziegler CJ, Wang H. Water-soluble ionic benzoporphyrins. Chem. Commun. 2012:6927-6929.

[148]. Sugita N, Hayashi S, Hino F, Takanami T. Palladium-catalyzed Kumada Coupling Reaction of bromoporphyrins with silylmethyl Grignard reagents: Preparation of silylmethyl-substituted porphyrins as a multipurpose synthon for fabrication of porphyrin systems. J. Org. Chem. 2012; 77:10488-10497. [PubMed: 23167823]

[149]. Dahal S, Krishnan V. Charge transfer excited states of zinc(II) derivatives of $\beta$-substituted dinitrotetraphenylporphyrin. Photochem. Photobiol. A: Chem. 1995; 89:105-112.

[150]. Bartoli JF, Battioni P, De Foor WR, Mansuy D. Synthesis and remarkable properties of iron $\beta$ polynitroporphyrins as catalysts for monooxygenation reactions. J. Chem. Soc. Chem. Commun. 1994:23-24.

[151]. Johnson AW, Oldfield D. The nitration and hydroxylation of ætioporphyrim I. J. Chem. Soc. 1965:4303-4312.

[152]. Drach JE, Longo FR. Electrophilic substitution on porphin. I. Nitration. J. Org. Chem. 1974; 39:3282-3284.

[153]. Ozette K, Battioni P, Leduc P, Bartoli J-F, Mansuy D. A new manganese- $\beta$-heptanitroporphyrin with extreme redox potentials: spectral, electrochemical and catalytic properties. Inorg. Chim. Acta. 1998; 272:4-6.

[154]. Watanabe E, Nishimura S, Ogoshi H, Yoshida Z. Orientation of electrophilic meso-substitution in metallooctaethylporphyrins. Tetrahedron. 1975; 31:1385-1390.

[155]. Fanning JC, Mandel FS, Gray TL. Datta-Gupta, N. The reaction of metalloporphyrins with nitrogen dioxide. Tetrahedron. 1979; 35:1251-1255.

[156]. Gong L-C, Dolphin D. Nitrooctaethylporphyrins: synthesis, optical and redox properties. Can. J. Chem. 1985; 63:401-405.

[157]. Catalano MM, Crossley MJ, Harding MM, King LG. Control of reactivity at the porphyrin periphery by metal ion co-ordination: a general method for specific nitration at the $\beta$-pyrrolic position of 5,10,15,20-tetraarylporphyrins. J. Chem. Soc. Chem. Commun. 1984:1535-1536.

[158]. Shea KM, Jaquinod L, Smith KM. Dihydroporphyrin synthesis: new methodology. J. Org. Chem. 1998; 63:7013-7021. [PubMed: 11672326]

[159]. Baldwin JE, Crossley MJ, DeBernardis JF. Efficient peripheral functionalization of porphyrins. Tetrahedron. 1982; 38:685-693.

[160]. Barnett GH, Smith KM. Reactions of some metalloporphyrin and metallochlorin $\pi$-cation radicals with nitrite. J. Chem. Soc. Chem. Commun. 1974:772-773.

[161]. Osuka A. Shimidzu, H. meso,meso-Linked porphyrin arrays. Angew. Chem. Int. Ed. Engl. 1997; 36:135-137.

[162]. Crossley MJ, Govenlock LJ, Prashar JK. Synthesis of porphyrin-2,3,12,13- and -2,3,7,8tetraones: building blocks for the synthesis of extended porphyrin arrays. J. Chem. Soc. Chem. Commun. 1995:2379-2380.

[163]. Baldwin JE, DeBernardis JF. Efficient peripheral functionalization of capped porphyrins. J. Org. Chem. 1977; 42:3986-3987.

[164]. Hombrecher HK, Gherdan VM, Ohm S, Cavaleiro JAS, Neves MGPMS, Condesso MF. Synthesis and electrochemical investigation of $\beta$-alkyloxy substituted mesotetraphenylporphyrins. Tetrahedron. 1993; 49:8569-8578.

[165]. Crossley MJ, Hambley TW, Mackay LG, Try AC, Walton RJ. Porphyrin analogues of Tröger's base: large chiral cavities with a bimetallic binding site. Chem. Soc. Chem. Commun. 1995:1077-1079. 
[166]. Crossley MJ, King GK, Newsom IA, Sheehan CS. Investigation of a 'reverse' approach to extended porphyrin systems. Synthesis of a 2,3- diaminoporphyrin and its reactions with adiones. J. Chem. Soc. Perkin Trans. 1. 1996:2675-2684.

[167]. Johnson CK, Dolphin D. Syntheses of chlorins possessing fused nitrogen-containing rings. Tetrahedron Lett. 1998; 39:4619-4622.

[168]. Crossley MJ, King LG, Pyke SM. A new and highly efficient synthesis of hydroxyporphyrins. Tetrahedron. 1987; 43:4569-4577.

[169]. Crossley MJ, Burn PL, Langford SJ, Pyke SM, Stark AG. A new method for the synthesis of porphyrin-a-diones that is applicable to the synthesis of trans-annular extended porphyrin systems. J. Chem. Soc. Chem. Commun. 1991:1567-1568.

[170]. Crossley MJ, Gosper JJ, Wilson MG. A general reductive denitration method for regiospecific deuteriation of the porphyrin nucleus: synthesis of [20-2.1]mesoporphyrin IX dimethyl ester. J. Chem. Soc. Chem. Commun. 1985:1798-1799.

[171]. Beavington R, Rees PA, Burn PL. A study on the oxidation of 2-hydroxyporphyrins to porphyrin-a-diones. J. Chem. Soc. Perkin Trans. 1. 1998:2847-2852.

[172]. Crossley MJ, King LG, Pyke SM, Tansey CW. Reaction of 5-nitrooctaethylporphyrins with nudeophiles. J.Porphyrins Phthalocyanines. 2002; 6:685-694.

[173]. Crossley MJ, King LG. A new method for regiospecific deuteration and reduction of 5,10,15,20-tetraphenylporphyrins: nucleophilic reaction of borohydride ion with 2nitro-5,10,15,20-tetraphenylporphyrins. J. Org. Chem. 1993; 58:4370-4375.

[174]. Crossley MJ, Harding MM, Tansey CW. A convenient synthesis of 2-Alkyl-5,10,15,20tetraphenylporphyrins: reaction of metallo-2-nitro-5,10,15,20-tetraphenylporphyrins with Grignard and organolithium reagents. J. Org. Chem. 1994; 59:4433-4437.

[175]. Crossley MJ, King LG. Reaction of metallo-2-nitro-5,10,15,20-tetraphenylporphyrins with oxyanions. Temperature-dependent competition between nucleophilic addition and singleelectron transfer processes. J. Chem. Soc. Perkin Trans. 1. 1996:1251-1260.

[176]. Crossley MJ, King LG, Simpson JL. Solvent-dependent ambident nucleophilicity of phenoxide ion towards nitroporphyrins: synthesis of 2-hydroxyaryl- and 2-aryloxy-5,10,15,20tetraphenylporphyrins by displacement of a nitro group. J. Chem. Soc. Perkin Trans. 1. 1997:3087-3096.

[177]. Jaquinod L, Gros CP, Khoury RG, Smith KM. A convenient synthesis of functionalized tetraphenylchlorins. Chem. Commun. 1996:2581-2582.

[178]. Luguya R, Fronczek FR, Smith KM, Vicente MGH. Synthesis of novel carboranychlorins with dual application in boron neutron capture therapy (BNCT) and photodynamic therapy (PDT). J. Appl. Rad. Isotopes. 2004; 61:1117-1123.

[179]. Jaquinod L, Gros CP, Olmstead MM, Antolovich M, Smith KM. First syntheses of fused pyrroloporphyrins. Chem. Commun. 1996:1475-1476.

[180]. Gros CP, Jaquinod L, Khoury RG, Olmstead MM, Smith KM. Approaches to $\beta$-fused porphyrinoporphyrins: pyrrolo- and dipyrromethanoporphyrins. J. Porphyrins Phthalocyanines. 1997; 1:201-212.

[181]. Jaquinod L, Khoury RG, Shea KM, Smith KM. Regioselective syntheses and structural characterizations of 2,3-dibromo- and 2,3,7,8,12,13-hexabromo-5,10,15,20tetraphenylporphyrins. Tetrahedron. 1999; 55:13151-13158.

[182]. Smith KM, Bisset GMF, Case JJ, Tabba HD. Polyformylation of copper(II) porphyrins. Tetrahedron Lett. 1980; 21:3747-3750.

[183]. Smith KM, Bisset GMF, Tabba HD. Polyformylation of copper(II) complexes of octa-alkyl porphyrins. J. Chem. Soc. Perkin Trans. 1. 1982:581-585.

[184]. Momenteau M, Loock B, Bisagni E. Five-coordinate iron(II) porphyrins derived from meso$\alpha, \beta, \gamma, \delta$ tetraphenylporphin: synthesis, characterization, and coordinating properties. Can. J. Chem. 1979; 57:1804-1813.

[185]. Buchler JW, Dreher C, Herget G. Metallkomplexe mit tetrapyrrolliganden, XLVIII. Vilsmeierformylierung von metallporphyrinen mit CoII, NiII, PdII, PtII, CuII, ZnII, CoIII, CrIII, MnIII, FeIII, AlIII, SiIV und PtIV in abhängigkeit vom zentralmetall. Liebigs Ann. Chem. 1988:43-54. 
[186]. Smith KM, Langry KC. Electrophilic substitution reactions of derivatives of deuteroporphyrinIX: deuteriation and Vilsmeier formylation. J. Chem. Soc. Perkin Trans. 1. 1983:439-444.

[187]. Vicente MGH, Rezzano IN, Smith KM. Efficient new syntheses of benzochlorins, benzoisobacteriochlorins and benzobacteriochlorins. Tetrahedron Lett. 1990; 31:1365-1368.

[188]. Vicente MGH, Smith KM. Vilsmeier reactions of porphyrins and chlorins with 3(dimethylamino)acrolein. New syntheses of benzochlorins, benzoisobacteriochlorins and dibenzobacteriochlorins and reductive coupling of porphyrins and chlorins using low-valent titanium complexes. J. Org. Chem. 1991; 56:4407-4418.

[189]. Montforts F-P, Scheurich G, Meier A, Haake G, Hoper F. An improved method for the preparation of formyldeuteroporphyrins. Synthesis of biologically relevant porphyrins. Tetrahedron Lett. 1991; 32:3477-3480.

[190]. Haake G, Meier A, Montforts F-P, Scheurich G, Zimmermann G. Synthese von chlorinen aus dem roten blutfarbstoff hämin. Liebigs Ann. Chem. 1992:325-336.

[191]. Senge MO, Hatscher SS, Wiehe A, Dahms K, Kelling A. The dithianyl group as a synthon in porphyrin chemistry: condensation reactions and preparation of formylporphyrins under basic conditions. J. Am. Chem. Soc. 2004; 126:13634-13635. [PubMed: 15493918]

[192]. Dahms K, Senge MO, Bakri Bakar M. Exploration of meso-substituted formylporphyrins and their Grignard and Wittig reactions. Eur. J. Org. Chem. 2007:3833-3848.

[193]. Takanami T, Wakita A, Sawaizumi A, Iso K, Onodera H, Suda K. One-pot synthesis of mesoformylporphyrins by SNAr reaction of 5,15-disubstituted porphyrins with (2pyridyldimethylsilyl)methyllithium. Org. Lett. 2008; 10:685-687. [PubMed: 18198882]

[194]. Clezy PS, Lim CL, Shannon JS. Chemistry of pyrrolic compounds. XXVII. Some aspects of the mass spectra and chemistry of meso-substituted porphyrins. Aust. J. Chem. 1974; 27:1103-1120.

[195]. Arnold DP, Johnson AW, Mahendran M. Some reactions of meso- formyloctaethylporhyrin. J. Chem. Soc. Perkin Trans. 1. 1978:366-370.

[196]. Runge S, Senge MO. Reaction of $\beta$-formylporphyrins with organometallicreagents. A facile method for the preparation of porphyrins with exocyclic double bonds. Tetrahedron. 1999; 55:10375-10390.

[197]. Hoper F, Montforts F-P. A simple synthesis of functionalized rac-chlorins via allylboration of porphyrin aldehydes. Liebigs Ann. Chem. 1995:1033-1038.

[198]. Smith KM, Bisset GMF, Bushell MJ. meso-Methylporphyrins and chlorins. Bioorg. Chem. 1980; 9:1-26.

[199]. Smith NW, Smith KM. Preparation of bacteriopetroporphyrins by partial synthesis from the Chlorobium chlorophylls. Energy Fuels. 1990; 4:675-688.

[200]. Smith KM, Bisset GMF. General synthesis of hydrocarbon-soluble porphyrins. J. Org. Chem. 1979; 44:2077-2081.

[201]. Smith KM, Bisset GMF, Bushell MJ. Recent studies on the Chloro- bium chlorophylls (bacteriochlorophylls-c). Int. J. Biochem. 1980; 12:695-700. [PubMed: 7450123]

[202]. Smith KM, Bisset GMF. Meso (methine) functionalization of octaalkylporphyrins. J. Chem. Soc. Perkin Trans. 1. 1981:2625-2630.

[203]. Bonfantini EE, Officer DL. The synthesis of butadiene-bridged porphyrindimers and styryl porphyrins using a porphyrin-derived Wittig reagent. Tetrahedron Lett. 1993; 34:8531-8534.

[204]. Burrell AK, Officer DL. Functionalizing porphyrins via Wittig reactions: a building block approach. Synlett. 1998:1297-1307.

[205]. Yeh C-Y, Miller SE, Carpenter SD, Nocera DG. Structurally homologous beta- and mesoamidinium porphyrins. Inorg. Chem. 2001; 40:3643-3646. [PubMed: 11421722]

[206]. Ol'shevskaya VA, Zaitsev AV, Luzgina VN, Kondratieva TT, Ivanov OG, Kononova EG, Petrovskii PV, Mironov AF, Kalinin VN, Hofmann J, Shtil AA. Novel boronated derivatives of 5,10,15,20-tetraphenylporphyrin: Synthesis and toxicity for drug-resistant tumor cells. Biorg. Med. Chem. 2006; 14:109-120.

[207]. Ponomarev GV, Borovkov VV, Sugiura K-I, Sakata Y, Shul'ga AM. Synthesis and properties of cis-1,2-bis(octaethylporphyrinyl)ethylene. Tetrahedron Lett. 1993; 34:2153-2156. 
[208]. Shul'ga AM, Ponomarev GV. Porphyrins. 23. Synthesis and properties of ethanebis(porphyrins). Khim. Geterotsikl. Soedin. 1988:339-344.

[209]. Higuchi H, Shimizu K, Ojima J, Sugiura K-I, Sakata Y. Synthesis and properties of ethenobridged porphyrin trimers. Tetrahedron Lett. 1995; 36:5359-5362.

[210]. Yashunsky DV, Ponomarev GV, Arnold DP. Synthesis of $\boldsymbol{m e s o}$-monosubstituted ethane- and trans-ethylenebis(porphyrins). Tetrahedron Lett. 1995; 36:8485-8488.

[211]. Zhilina ZI, Ishkov YV, Voloshanovskii IS, Andronati ASA. Reductive dimerization of the cuprous complex of 2-formyl-5,10,15,20-tetraphenylporphyrin. Dokl. Akad. Nauk USSR. 1988; 303:377-380.

[212]. Senge MO, Gerzevske KR, Vicente MGH, Forsyth TP, Smith KM. Models for the photosynthetic reaction center - synthesis and structure of 1,2-cis- and -trans-ethene and skewed 1,1-carbinol bridged porphyrin dimers. Angew. Chem. Int. Ed. Engl. 1993; 32:750-753.

[213]. Jaquinod L, Nurco DJ, Medforth CJ, Pandey RK, Forsyth TP, Olmstead MM, Smith KM. Synthesis and characterization of bis(chlorin)s from the McMurry reaction of formylchlorins. Angew. Chem. Int. Ed. Engl. 1996; 35:1013-1016.

[214]. Tokuji S, Awane H, Yorimitsu H, Osuka A. Direct arylation of meso-formyl porphyrin. Chem. Eur. J. 2013; 19:64-68. [PubMed: 23255083]

[215]. Callot HJ, Castro B, Selve C. Porphyrines synthetiques porteuses dechaines laterales peptidiques. I. Atropoisomérie d'amides cis(mésotétraphénylporphyrinyl)-3 propénoïques. Tetrahedron Lett. 1978; 32:2877-2880.

[216]. Momenteau M, Loock B, Rougee M. Five-coordinate iron(II) porphyrins derived from meso$a, \beta, \gamma, \delta$ tetraphenylporphin: synthesis, characterization, and coordinating properties. Can. J. Chem. 1979; 57:1804-1813.

[217]. Dolphin D, Sivasothy R. The preparation of porphyrin S-411 (dehydroco-prophyrin) and harderoporphyrin from protoporphyrin-IX. Can. J. Chem. 1981; 59:779-85.

[218]. Arnold DP, Nitschinsk LJ. Porphyrin dimers linked by conjugated butadiynes. Tetrahedron. 1992; 48:8781-8792.

[219]. Gosper JJ, Ali M. A conformationally constrained conjugated porphyrindimer. J. Chem. Soc. Chem. Commun. 1994:1707-1708.

[220]. Kahl SB, Schaeck JJ, Koo M-S. Improved methods for the synthesis of porphyrin alcohols and aldehydes from protoporphyrin IX dimethyl ester and their further modification. J. Org. Chem. 1997; 62:1875-1880.

[221]. Screen TEO, Blake IM, Rees LH, Clegg W, Borwick SJ, Anderson HL. Making conjugated connections to porphyrins: a comparison of alkyne, alkene, imine and azo links. J. Chem. Soc., Perkin Trans. 1. 2002:320-329.

[222]. Omote M, Ando A, Koyama M, Takagi T, Kumadaki I. Synthesis of fluorinated analogs of hematoporphyrin II. Heterocycles. 1994; 39:381-384.

[223]. Jeandon C, Bauder C, Callot HJ. Selective acetylation of porphyrins possessing a free pyrrolic position as a tool for petroporphyrin analysis. A reinvestigation. Energy Fuels. 1990; 4:665-667.

[224]. Shiau F-Y, Whyte BJ, Castelfranco PA, Smith KM. Partial syntheses of the isomerically pure magnesium(II) protoporphyrin IX mono-methyl esters and their identification. J. Chem. Soc. Perkin Trans. 1. 1991:1781-1785.

[225]. Kusch D, Montforts F-P. Enantioselective synthesis of hematoporphyrin stereoisomers. Tetrahedron: Asymm. 1995; 6:867-870.

[226]. Kusch D, Tollner E, Lincke A, Montforts F-P. A simple, chirogenic, enantioselective synthesis of chlorins and isobacteriochlorins. Angew. Chem. Int. Ed. Engl. 1995; 34:784-787.

[227]. Kusch D, Montforts F-P. Synthesis of enantiomerically pure hydroxuyeth- ylporphyrins and their transformation into optically active chlorin derivatives. Part 4. Liebigs Ann. Chem. 1996:83-86.

[228]. Jiang X, Smith KM. 3,8-Di-ethynyl-3,8-devinylprotoporphyrin IX and its hemin. J. Chem. Soc. Chem. Commun. 1993:1054-1056.

[229]. Jiang X, Smith KM. Syntheses of some $\beta$-substituted alkyne porphyrins related to protoporphyrin-IX. J. Chem. Soc. Perkin Trans. 1996; 1:1601-1606. 
[230]. Bauder C, Ocampo R, Callot HJ. Total synthesis of cyclopentenoporphyrins of sedimentary origin: deoxophylloerythroetioporphyrin, chlorophyll $\mathrm{c}$ fossils and related compounds. Tetrahedron. 1992; 48:5135-5150.

[231]. Malinen PK, Tauber AY, Hynninen PH, Montforts F-P. An unexpected Wittig reaction of dimethyl 3,3'-(3-formyl-2,7,12,18-tetramethyl-21H, 23H-porphyrin-13,17-diyl)-dipropionate. Tetrahedron Lett. 1997; 38:3381-3382.

[232]. Evans B, Smith KM, Cavaleiro JAS. Bile pigment studies. Part 4. Some novel reactions of metalloporphyrins with thallium(III) and cerium(IV) salts. Ring cleavage of mesotetraphenylporphyrin. J. Chem. Soc. Perkin Trans. 1. 1978:768-773.

[233]. Barnett GH, Evans B, Smith KM, Besecke S, Fuhrhop J-H. Synthesis of meso-pyridinium porphyrin salts. Tetrahedron Lett. 1976:4009-4012.

[234]. Fuhrhop J-H, Wanja U, Bunzel M. Metalloporphyrins in polymeric matrices, micelles and vesicles, V. 5-(1'-Methyl-4,4'-bipyridinium-1-yl)octaethylporphyrin dichloride, a mesoviologenporphyrinate. Liebigs Ann. Chem. 1984:426-434.

[235]. Fuhrhop J-H, Kruger W, Meding U. Synthesis and reactivity of meso-(3-carbamoylpyridinio)porphyrins. Liebigs Ann. Chem. 1981:1367-1377.

[236]. Shine HJ, Padilla AG, Wu S-M. Ion radicals. 45. Reactions of zinc tetraphenylporphyrin cation radical perchlorate with nucleophiles. J. Org. Chem. 1979; 44:4069-4074.

[237]. El Kahef L, Giraudeau A. P-Substitution de la méso-tétraphénylporphyrine de zinc par voie électrochimique. Can. J. Chem. 1991; 69:1161-1165.

[238]. Smith KM, Barnett GH, Evans B, Martynenko Z. Novel meso-substitution reactions of metalloporphyrins. J. Am. Chem. Soc. 1979; 101:5953-5961.

[239]. Ruhlman L, Giraudeau A. One-pot electrochemical generation of a porphyrin dimer with a bis(diphenylphosphonium)acetylene bridge. Chem. Commun. 1996:2007-2008.

[240]. Giraudeau A, Ruhlman L, El Kahef L, Gross M. Electrosynthesis and characterization of symmetrical and unsymmetrical linear porphyrin dimers and their precursor monomers. J. Am. Chem. Soc. 1996; 118:2969-2979.

[241]. Ruhlman L, Lobstein S, Gross M, Giraudeau A. An electrosynthetic path toward pentaporphyrins. J. Org. Chem. 1999; 64:1352-1355.

[242]. Ogawa T, Nishimoto Y, Yoshida N, Ono N, Osuka A. Completely regioselective synthesis of directly linked meso, meso and meso, $\beta$ porphyrin dimers by one-pot electrochemical oxidation of metalloporphyrins. Angew. Chem. Int. Ed. 1999; 38:176-179.

[243]. Yoshida N, Shimidzu H, Osuka A. Meso-meso linked diporphyrins from 5,10,15-trisubstituted porphyrins. Chem. Lett. 1998:55-56.

[244]. Nakano A, Shimidzu H, Osuka A. Facile regioselective meso-iodination of porphyrins. Tetrahedron Lett. 1998; 39:9489-9492.

[245]. Dolphin D, Felton RH, Borg DC, Fajer J. Isoporphyrins. J. Am. Chem. Soc. 1970; 92:743-745.

[246]. Lee WA, Bruice TC. Transfer of oxygen from percarboxylic acids and alkyl hydroperoxides to (meso-tetraphenylporphinato)cobalt(III) chloride. Inorg, Chem. 1986; 25:131-135.

[247]. Senge MO. Stirring the porphyrin alphabet soup - functionalization reactions for porphyrins. Chem. Commun. 2011; 47:1943-1960.

[248]. Senge MO. Nucleophilic substitution as a tool for the synthesis of unsymmetrical porphyrins. Acc. Chem. Res. 2005; 38:733-743. [PubMed: 16171316]

[249]. Senge MO, Feng X. Synthesis of directly meso-meso linked bisporphyrins using organolithium reagents. Tetrahedron Lett. 1999; 40:4165-4168.

[250]. Senge MO, Feng X. Regioselective reaction of 5,15-disubstituted porphyrins with organolithium reagents - synthetic access to 5,10,15-trisubstituted porphyrins and directly mesomeso-linked bisporphyrins. J. Chem. Soc., Perkin Trans. 1. 2000:3615-3621.

[251]. Feng X, Senge MO. An efficient synthesis of highly functionalized asymmetric porphyrins with organolithium reagents. J. Chem. Soc., Perkin Trans. 1. 2001:1030-1038.

[252]. Feng X, Bischoff I, Senge MO. Mechanistic studies on the nucleophilic reaction of porphyrins with organolithium reagents. J. Org. Chem. 2001; 66:8693-8700. [PubMed: 11749596] 
[253]. Krattinger B, Callot HJ. New routes from porphyrins to stable phlorins. Meso-alkylation and reduction of meso-tetraphenyl- and octaalkylporphyrins. Tetrahedron Lett. 1996; 37:7699-7702.

[254]. Jiang X, Nurco DJ, Smith KM. Direct meso-alkylation of meso-formylporphyrins using Grignard reagents. Chem. Commun. 1996:1759-1760.

[255]. Segawa H, Azumi R, Shimidzu T. Direct hydroxylation at the meso position of gold(III) tetraphenylporphyrin by nucleophilic addition: novel hydroxyphlorin derivatives. J. Am. Chem. Soc. 1992; 114:7564-7565.

[256]. Ogoshi H, Sugimoto H, Yoshida Z-I, Kobayashi H, Sakai H, Maeda Y. Syntheses and magnetic properties of aryliron(III) complexes of octaethylporphyrins. J. Organomet. Chem. 1982; 234:185-195.

[257]. Cocolios P, Lagrange G, Guilard R. Synthese et caracterisation par RMN 1H d'alkyl(aryl)ferriporphyrines a liaison $\sigma$ metal carbone. J. Organomet. Chem. 1983; 253:65-79.

[258]. Callot HJ, Schaeffer E. Model for the in vivo transformation of cyto- chrome P-450 into "green pigments". Tetrahedron Lett. 1980; 21:1335-1338.

[259]. Dolphin D, Halko DJ, Johnson E. Reversible cobalt-nitrogen alkyl and acyl group migration in cobalt porphyrins. Inorg. Chem. 1981; 20:4348-4351.

[260]. Lange M, Mansuy D. N-Substituted porphyrin formation from carbene iron-porphyrin complexes: a possible pathway for cytochrome P450 heme destruction. Tetrahedron Lett. 1981; 22:2561-2564.

[261]. Ortiz de Montellano PR, Kunze KL, Augusto O. Hemoprotein destruction. Iron-nitrogen shift of a phenyl group in a porphyrin complex. J. Am. Chem. Soc. 1982; 104:3545-3546.

[262]. Callot HJ, Metz F. J. Acid-catalysed intramolecular cobalt to nitrogen aryl migration and intramolecular reverse reaction in cobalt porphyrins. Synthesis of $N$-phenylporphyrins. Chem. Soc. Chem. Commun. 1982:947-948.

[263]. Setsune J-I, Dolphin D. Organometallic aspects of cytochrome-p-450 metabolism. Can. J. Chem. 1987; 65:459-467.

[264]. Kadish KM, Caemelbecke EV, D’Souza F, Medforth CJ, Smith KM, Tabard A, Guilard R. Generation of a stable 8-bonded Fe(IV) porphyrin. Formation and reactivity of [(OETPP)FeIV(C6H5)n+ where $\mathrm{n}=1,2$ or 3 and OETPP is the dianion of $2,3,7,8,12,13,17,18$ octaethyl-5,10,15,20-tetraphenylporphyrin. Organometallics. 1993; 12:2411-2413.

[265]. McCombie SW, Smith KM. Oxophlorin (oxyporphyrin) synthesis. Tetrahedron Lett. 1972; 24:2463-2464.

[266]. Barnett GH, Hudson MF, McCombie SW, Smith KM. Synthesis of oxophlorins (oxyporphyrins) from zinc and magnesium porphyrins. J. Chem. Soc. Perkin Trans. 1. 1973:691-696.

[267]. Stolzenberg AM, Glazer PA, Foxman BM. Structure, reactivity, and electrochemistry of freebase $\beta$-oxoporphyrins and metallo- $\beta$-oxoporphyrins. Inorg. Chem. 1986; 25:983-991.

[268]. Chang CK, Wu W. On the hydrogen peroxide/sulfuric acid oxidation of mesoporphyrin. Synthesis of mesoporphyrindiones. J. Org. Chem. 1986; 51:2134-2138.

[269]. Bonnett R, Cornell P, McDonagh AF. The meso-reactivity of porphyrins and related compounds. Part VII. Benzoyloxylation of phenylpyrroles and of octaethylporphyrin. J. Chem. Soc. Perkin Trans. 1976; 1:794-800. [PubMed: 944194]

[270]. Jackson AH, Rao KRN, Wilkins M. Synthetic and biosynthetic studies of porphyrins. Part 11. The synthesis of meso oxygenated protoporphyrins. J. Chem. Soc. Perkin Trans. 1. 1987:307312.

[271]. Fuhrhop J-H, Besecke S, Subramanian J. A stable octaethyloxophlorin radical. J. Chem. Soc. Chem. Commun. 1973:1-2.

[272]. Fuhrhop J-H, Besecke S, Subramanian J, Mengersen C, Riesner D. Reactions of oxophlorins and their $\pi$ radicals. J. Am. Chem. Soc. 1975; 97:7141-7152.

[273]. Khoury RG, Jaquinod L, Shachter AM, Nelson NY, Smith KM. Stabilization of neutral oxophlorin $\pi$-radicals by bulky meso-alkyl groups. Chem. Commun. 1997:215-216.

[274]. Bonnett R, Nizhnik AN, Berenbaum MC. Second generation tumour photosensitisers: the synthesis of octa-alkyl chlorins and bacteriochlorins with graded amphiphilic character. J. Chem. Soc. Chem. Commun. 1989:1822-1823. 
[275]. Adams KR, Berenbaum MC, Bonnett R, Nizhnik AN, Salgado A, Vallés MA. Second generation tumour photosensitisers: the synthesis and biological activity of octaalkyl chlorins and bacteriochlorins with graded amphiphilic character. J. Chem. Soc. Perkin Trans. 1. 1992:14651470.

[276]. Bruckner C, Dolphin D. 2,3-vic-Dihydroxy-meso-tetraphenylchlorins from the osmium tetroxide oxidation of meso-tetraphenylporphyrin. Tetrahedron Lett. 1995; 36:3295-3298.

[277]. Chang CK, Sotiriou C. C-Hydroxy- and C-methylchlorins. A convenient route to heme d and bonellin model compounds. J. Org. Chem. 1985; 50:4989-4991.

[278]. Chang CK, Sotiriou C. Migratory aptitudes in pinacol rearrangement of vic-dihydroxychlorins. J. Heterocycl. Chem. 1985; 22:1739-1741.

[279]. Nakamura K, Osamura Y. MO study of the possibility of a concerted mechanism in the pinacol rearrangement. J. Phys. Org. Chem. 1990; 3:737-745.

[280]. Kozyrev AN, Pandey RK, Medforth CJ, Zheng G, Dougherty TJ, Smith KM. Syntheses of stable bacteriochlorophyll-a derivatives as potential photosensitizers for photodynamic therapy. Tetrahedron Lett. 1996; 37:747-751.

[281]. Pandey RK, Isaac M, MacDonald I, Medforth CJ, Senge MO, Dougherty TJ, Smith KM. Pinacol-pinacolone rearrangements in vic-dihydroxychlorins and bacteriochlorins: effect of substituents at the peripheral positions. J. Org. Chem. 1997; 62:1463-1472.

[282]. Chang CK, Sotiriou C. A novel method of functionalizing the ethyl chain of octaethylporphyrin. J. Org. Chem. 1987; 52:926-929.

[283]. Chang CK, Sotiriou C, Wu W. Differentiation of bacteriochlorin and isobacteriochlorin formation by metallation. High yield synthesis of porphyrindiones via $\mathrm{OsO} 4$ oxidation. J. Chem. Soc. Chem. Commun. 1986:1213-1215.

[284]. Bruckner C, Dolphin D. $\beta, \beta$ '-Dihydroxylation of meso-tetraphenylchlorins and metallochlorins. Tetrahedron Lett. 1995; 36:9425-9428.

[285]. Pandey RK, Shiau F-Y, Isaac M, Ramaprasad S, Dougherty TJ, Smith KM. Substituent effects in tetrapyrrole subunit reactivity and pinacolpinacolone rearrangements: vic-dihydroxychlorins and vic-dihydroxybacterio-chlorins. Tetrahedron Lett. 1992; 33:7815-7818.

[286]. Pandey RK, Shiau F-Y, Sumlin AB, Dougherty TJ, Smith KM. Syntheses of new bacteriochlorins and their antitumor activity. Bioorg. Med. Chem. Lett. 1994; 4:1263-1267.

[287]. Pandey RK, Constantine S, Tsuchida T, Zheng G, Medforth CJ, Aoudia M, Kozyrev AN, Rodgers MAJ, Kato H, Smith KM, Dougherty TJ. Synthesis, photophysical properties. in vivo photosensitizing efficacy, and human serum albumin (HSA) binding properties of some novel bacteriochlorins. J. Med. Chem. 1997; 40:2770-2779. [PubMed: 9276023]

[288]. Beavington R, Rees PA, Burn PL. A study on the oxidation of 2-hydroxyporphyrins to porphyrin-a-diones . J. Chem. Soc. Perkin Trans. 1. 1998:2847-2852.

[289]. Crossley MJ, Prashar JK. Thiophene-appended porphyrin systems. Tetrahedron Lett. 1997; 38:6751-6754.

[290]. Gulyas PT, Langford SJ, Lokan NR, Ranasinghe MG, Paddon-Row MN. Convenient synthetic route to rigid donor- $\{$ bridge $\}$-acceptor systems involving porphyrin and phenanthroline annulation of norbornylogous bridges via 2,3-norbornanediones. J. Org. Chem. 1997; 62:30383039. [PubMed: 11671681]

[291]. Sessler JL, Brown CT, O’Connor D, Springs SL, Wang R, Sathiosatham M, Hirose T. A rigid chlorin-naphthalene diimide conjugate. A possible new noncovalent electron transfer model system. J. Org. Chem. 1998; 63:7370-7374.

[292]. Crossley MJ, McDonald JA. Fused porphyrin-imidazole systems: new building blocks for synthesis of porphyrin arrays. J. Chem. Soc. Perkin Trans. 1. 1999:2429-2431.

[293]. Bonnett R, McDonagh AF. The meso-reactivity of porphyrins and related compounds. Part VI. Oxidative cleavage of the haem system. The four isomeric biliverdins of the IX series. J. Chem. Soc., Perkin Trans. 1. 1973:881-888.

[294]. Crusats J, Suzuki A, Mizutani , Ogoshi H. Regioselective porphyrin bridge cleavage controlled by electronic effects. Coupled oxidation of 3-demethyl-3-(trifluoromethyl)mesohemin IX and identification of its four biliverdin derivatives. J. Org. Chem. 1998; 63:602-607. [PubMed: 11672050] 
[295]. Wasser PKW, Fuhrhop J-H. The photooxygenation of metalloporphyrins and metallochlorins. Ann. N.Y. Acad. Sci. 1973; 206:533-547. [PubMed: 4518405]

[296]. Catalano MM, Crossley MJ, Harding MM, King LG. Control of reactivity at the porphyrin periphery by metal ion co-ordination: a general method for specific nitration at the $\beta$-pyrrolic position of 5,10,15,20-tetraarylporphyrins. J. Chem. Soc., Chem. Commun. 1984:1535-1536.

[297]. Ongayi O, Vicente MGH, Ghosh B, Fronczek FR, Smith KM. Bilitrienones from the chemical oxidation of dodecasubstituted porphyrins. Tetrahedron. 2010; 66:63-67. [PubMed: 20644655]

[298]. Bonnett R, Dimsdale MJ. The meso-reactivity of porphyrins and related compounds. Part V. The meso-oxidation of metalloporphyrins. J. Chem. Soc., Perkin Trans. 1. 1972:2540-2548.

[299]. Ongayi O, Vicente MGH, Ou Z, Kadish KM, Kumar MR, Fronczek FR, Smith KM. Synthesis and electrochemistry of undecasubstituted metallo-benzoylbiliverdins. Inorg. Chem. 2006; 45:1463-1470. [PubMed: 16471957]

[300]. Fuhrhop J-H, Wasser PKW, Subramanian J, Schrader U. Formylbiliverdine und ihre metallkomplexe. Liebigs Ann. Chem. 1974:1450-1466.

[301]. Cox GS, Whitten DG. Mechanisms for the photooxidation of protoporphyrin IX in solution. J. Am. Chem. Soc. 1982; 104:516-521.

[302]. Brault D, Aveline B, Delgado O, Vever-Bizet C. Chlorin-type photosensitizers derived from vinyl porphyrins. Proc. SPIE. 1994; 2325:40-47.

[303]. Iakovides P, Smith KM. Synthesis of oxygen analogues of the sulfchlorins. Tetrahedron Lett. 1990; 31:3853-3856.

[304]. Iakovides P, Smith KM. Syntheses of oxygen analogues of sulfhemes-A and -C. Tetrahedron. 1996; 52:1123-1148.

[305]. Smith KM, Brown SB, Troxler RF, Lai J-J. Mechanism of photo-oxygenation of mesotetraphenylporphyrin metal complexes. Tetrahedron Lett. 1980; 21:2763-2766.

[306]. Smith KM, Brown SB, Troxler RF, Lai J-J. Photo-oxygenation of meso-tetraphenylporphyrin metal complexes. Photochem. Photobiol. 1982; 36:147-152. [PubMed: 7122709]

[307]. Matsuura T, Inoue K, Ranade AC, Saito I. Photooxygenation of magnesium mesotetraphenylporphyrin. Photochem. Photobiol. 1980; 31:23-26.

[308]. Cavaleiro JAS, Neves MGPMS, Hewlins MJE, Jackson AH. The photo-oxidation of mesotetraphenylporphyrins. J. Chem. Soc., Perkin Trans. 1. 1990:1937-11943.

[309]. Whitlock HW Jr. Hanauer R, Oester MY, Bower BK. Diimide reduction of porphyrins. J. Am. Chem. Soc. 1969; 91:7485-7489.

[310]. Ulman A, Gallucci J, Fisher D, Ibers JA. Facile syntheses of tetraalkylchlorin and tetraalkylporphyrin complexes and comparison of the structures of the tetramethylchlorin and tetramethylporphyrin complexes of nickel(II). J. Am. Chem. Soc. 1980; 102:6852-6854.

[311]. Vasudevan J, Stibrany RT, Bumby J, Knapp S, Potenza JA, Emge TJ, Schugar HJ. J. An edgeover-edge $\mathrm{Zn}$ (II) bacteriochlorin dimer having an unshifted Qy band. The importance of $\pi$ Overlap. J. Am. Chem. Soc. 1996; 118:11676-11677.

[312]. Stolzenberg AM, Simerly SW, Steffey BD, Haymond GH. An edge-over-edge Zn(II) bacteriochlorin dimer having an unshifted Qy band. The importance of $\pi$-overlap. J. Am. Chem. Soc. 1997; 119:11843-11854.

[313]. Smith KM, Lai J-J. Syntheses of heme-d models. J. Am. Chem. Soc. 1984; 106:5746-5748.

[314]. Burns DH, Lai J-J, Smith KM. Syntheses of chlorins from unsymmetrically substituted iron(III) porphyrins. J. Chem. Soc. Perkin Trans. 1. 1988:3119-3131.

[315]. Whitten DG, Yau JC, Carroll FA. Photochemistry and oxidation-reduction reactions of tin porphyrins. J. Am. Chem. Soc. 1971; 93:2291-2296.

[316]. Fuhrhop J-H, Lumbantobing T. The redox properties of tin(IV) and germanium(IV) octaethylporphinato-dihydroxides as compared to other metallooctaethylporphins. Tetrahedron Lett. 1970; 32:2815-2818.

[317]. Harel Y, Manassen J. Photoreduction of tetraphenylporphyrins by amines in the visible. Photochemical syntheses of reduced tetraphenylporphyrins and the mechanism of photoreduction. J. Am. Chem. Soc. 1978; 100:6228-6234.

Curr Org Synth. Author manuscript; available in PMC 2015 February 01. 
[318]. Wolf H, Scheer H. Photochemische hydrierung von phäoporphyrinen: 7,8-cis-phäophorbide. Liebigs Ann. Chem. 1973:1710-1740.

[319]. Smith KM, Simpson DJ. Site-specific reduction of unsymmetrically substituted porphyrins to give isomerically pure chlorins. J. Chem. Soc. Chem. Commun. 1987:613-614.

[320]. Iakovides P, Simpson DJ, Smith KM. Regioselective photoreduction of zinc(II) porphyrins to give chlorins. Photochem. Photobiol. 1991; 54:335-343. [PubMed: 1784634]

[321]. Kämpfen U, Eschenmoser A. Porphyrin synthesis by ring transplantation. Tetrahedron Lett. 1985; 26:5899-5902.

[322]. Closs GL, Closs LE. Negative ions of porphin metal complexes. J. Am. Chem. Soc. 1963; 85:818-819.

[323]. Buchler JW, Schneehage HH. Metallkomplexe mit tetrapyrrol-liganden. V. Zum einflu $\beta$ des zentralmetalls auf die hydrierung des octaäthylporphin-systems. Tetrahedron Lett. 1972:38033806.

[324]. Buchler JW, Puppe L. Metallkomplexe mit Tetrapyrrol-Liganden, II1) Metallchelate des a. $\gamma$ Dimethyl-a. $\gamma$-dihydro-octaäthylporphins durch reduzierende Methylierung von Octaäthylporphinato-zink. Liebigs Ann. Chem. 1970; 740:142-163.

[325]. Dwyer PN, Buchler JW, Scheidt WR. Crystal structure and molecular stereochemistry ofa, $\gamma$ dimethyl-a, $\gamma$-dihydrooctaethylporphinatonickel(II). J. Am. Chem. Soc. 1974; 96:2789-2795.

[326]. Shulga AM, Sinyakov GN, Filatov IV, Gurinovich GP, Dzilinski K. Study of electronic structure of Zn-porphyrin and Zn-chlorin $\pi$-anions $J$. Mol. Struct. 1995; 348:65-68. 


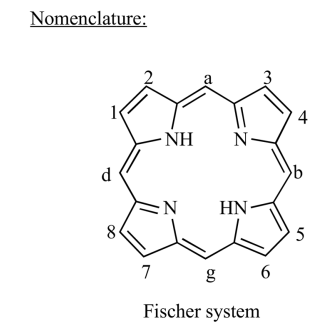

Classical porphyrins:
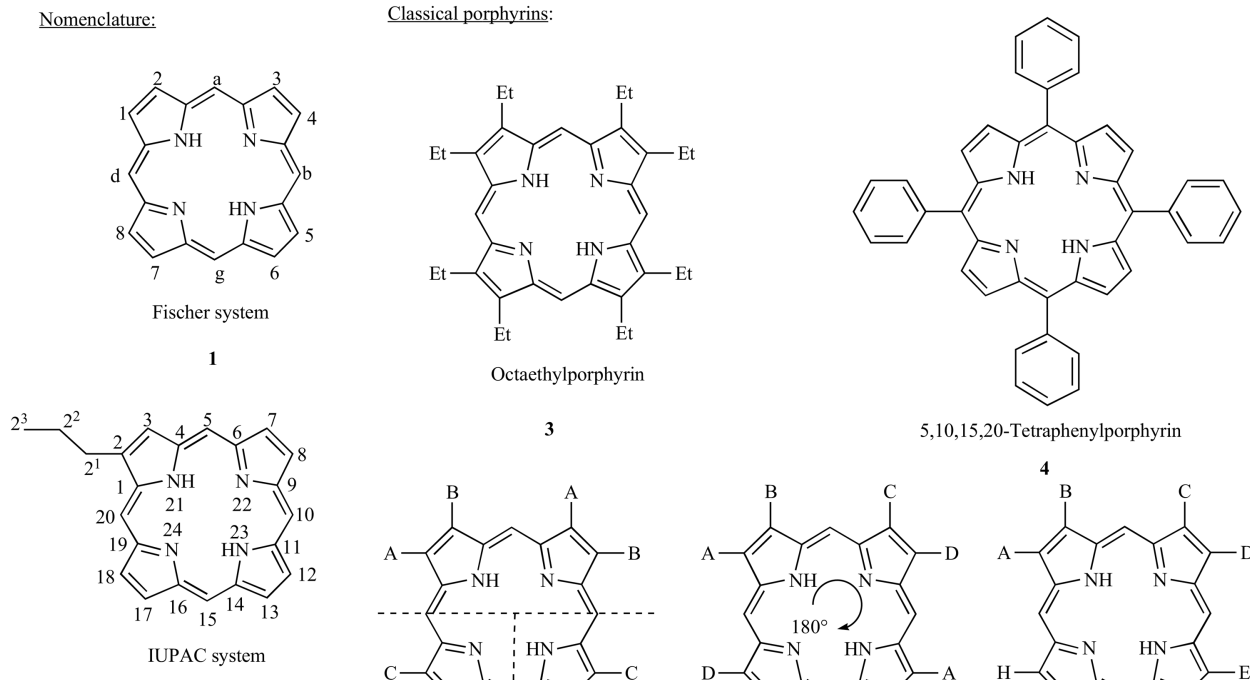

Octaethylporphyrin

3
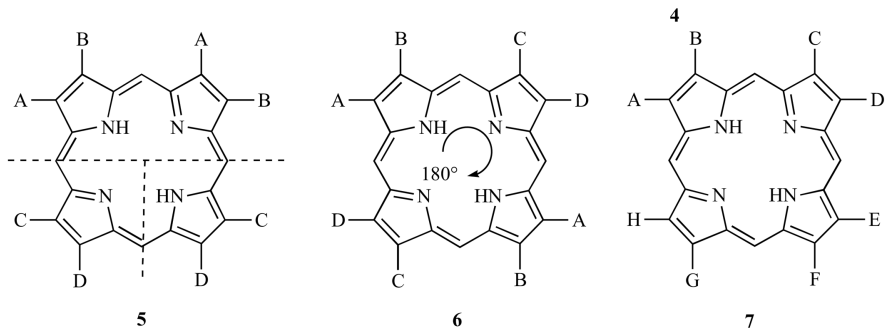

Fig. (1).

Porphyrin nomenclature. 


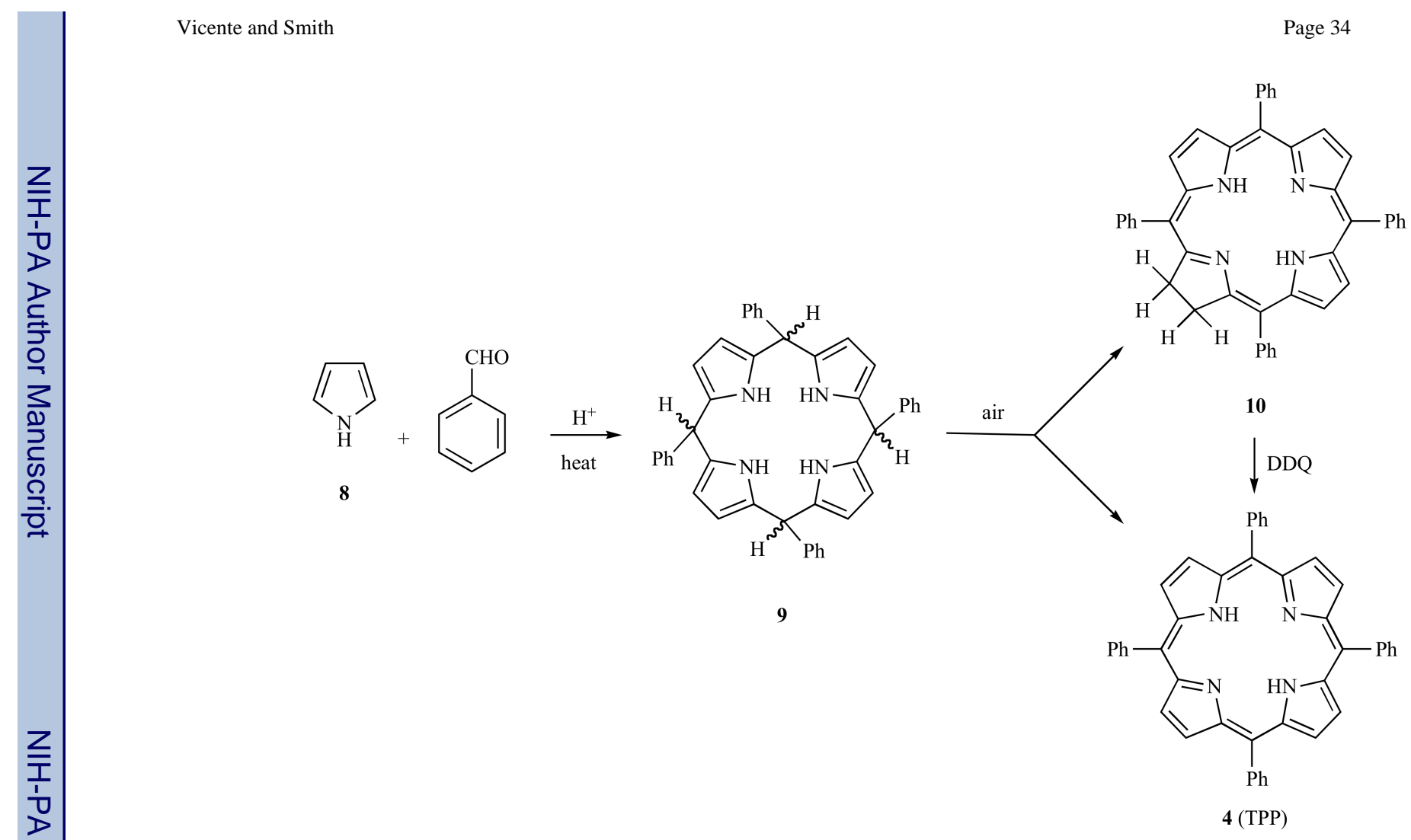

Scheme 1.

Curr Org Synth. Author manuscript; available in PMC 2015 February 01. 


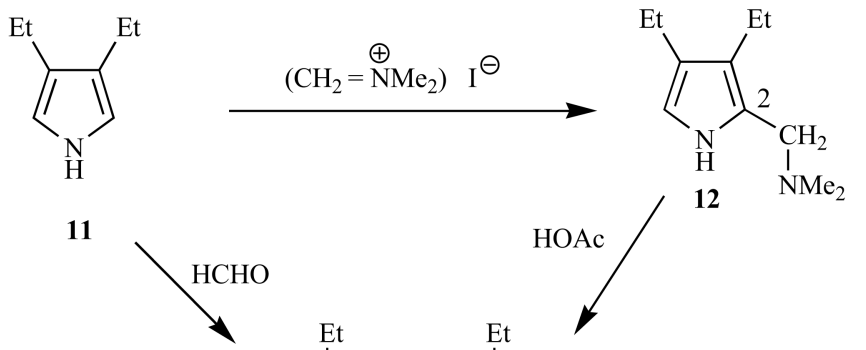

$\mathrm{HOAc}$,
$\mathrm{K}_{3} \mathrm{Fe}(\mathrm{CN})_{6}$<smiles>CCc1c(CO)[nH]c(C(=O)O)c1CC</smiles>
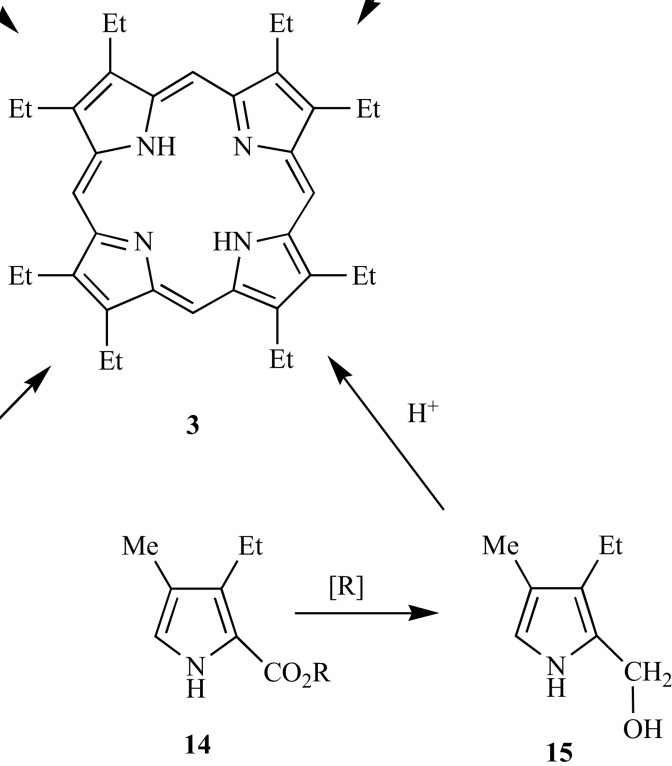

Scheme 2.

Curr Org Synth. Author manuscript; available in PMC 2015 February 01. 

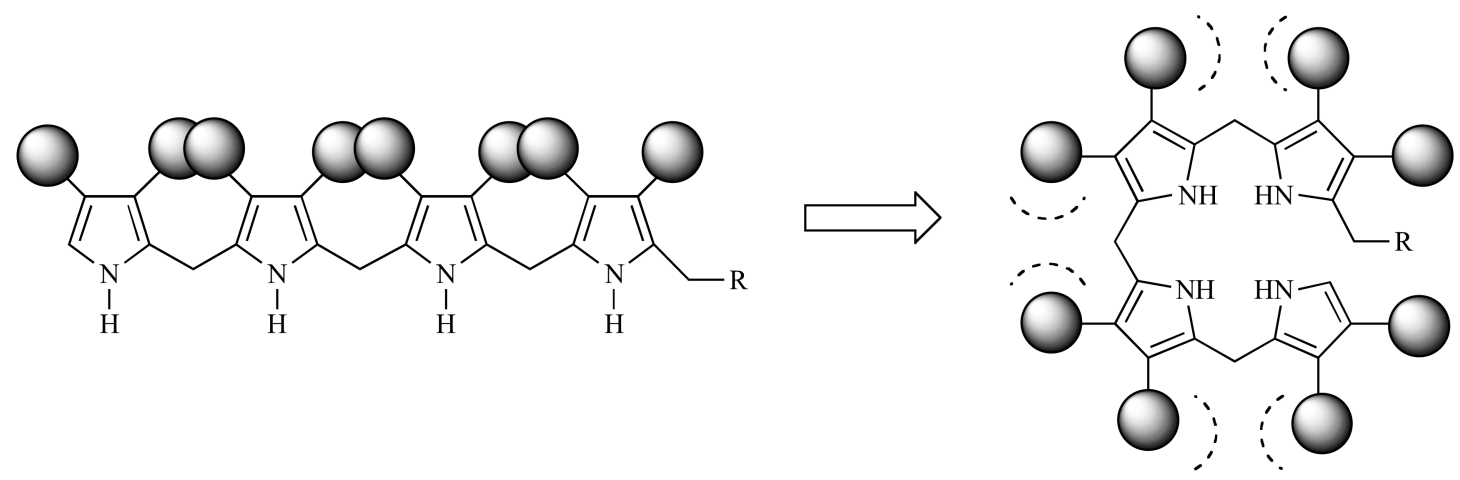

16

Scheme 3.

Curr Org Synth. Author manuscript; available in PMC 2015 February 01. 


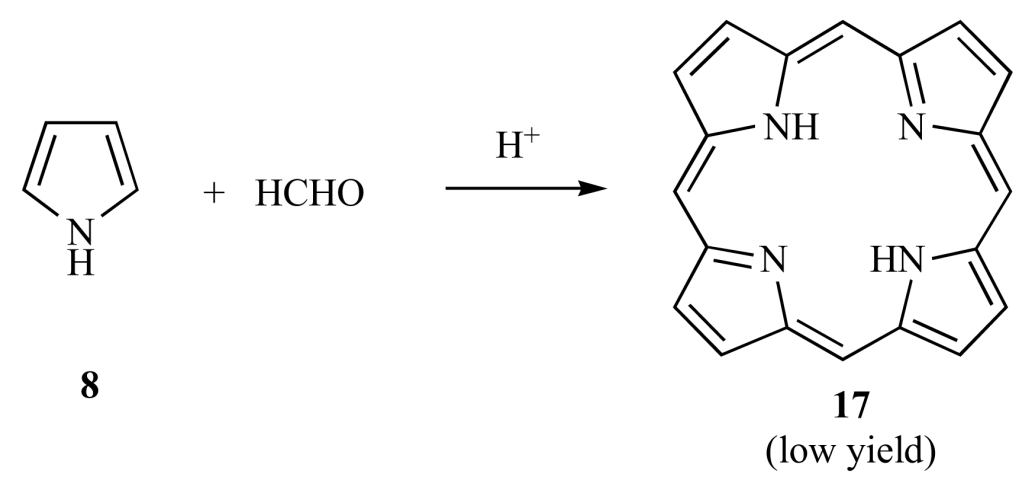

Scheme 4. 


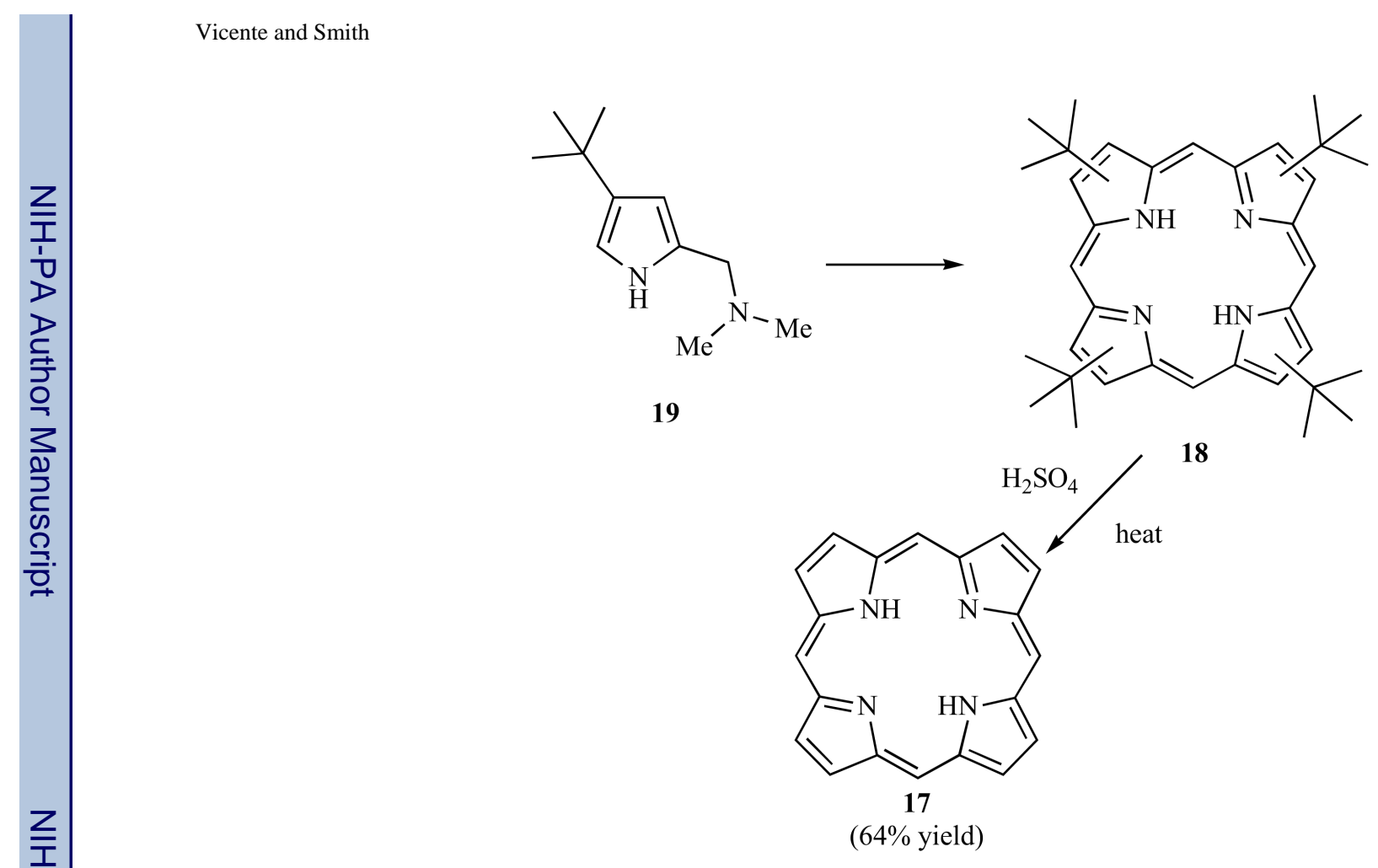

Scheme 5. 

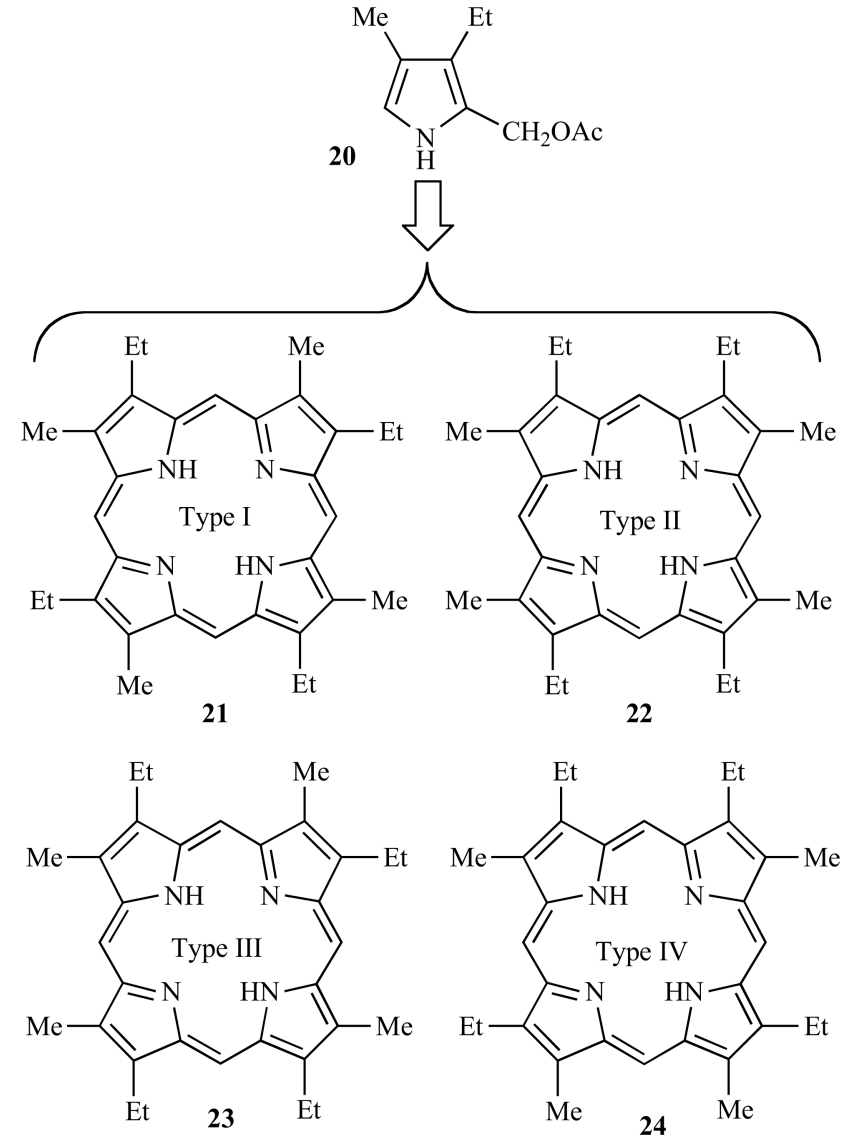

Scheme 6.

Curr Org Synth. Author manuscript; available in PMC 2015 February 01. 

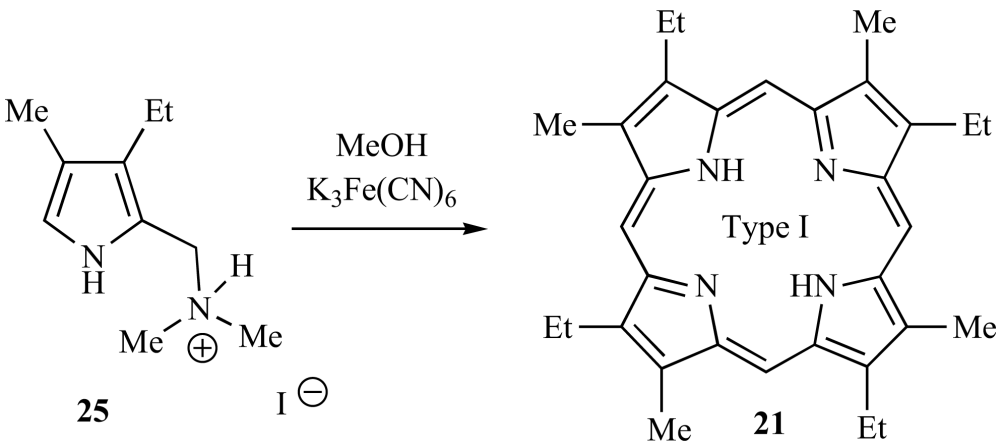

Scheme 7.

Curr Org Synth. Author manuscript; available in PMC 2015 February 01. 


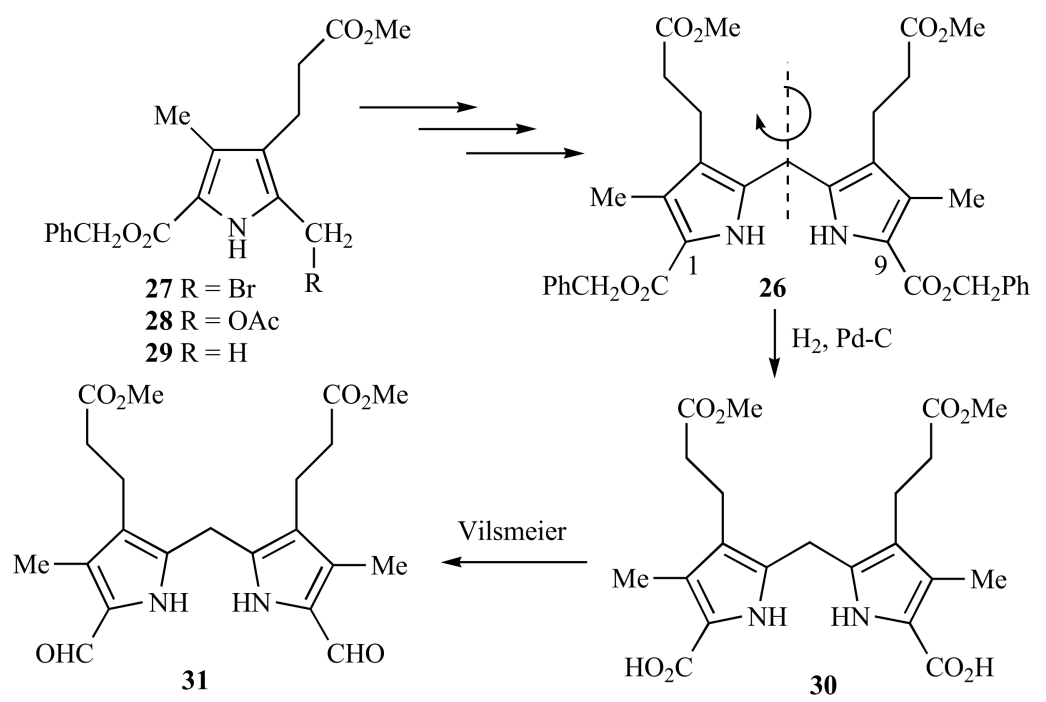

Scheme 8. 
<smiles>CCc1c(COC(C)=O)[nH]c(C(=O)OCc2ccccc2)c1C</smiles>
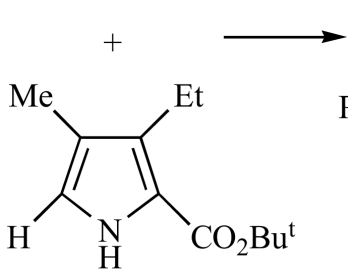<smiles>CCc1c(Cc2[nH]c(C(=O)OCC(C)(C)C)c(CC)c2C)[nH]c(C(=O)O)c1C</smiles>

34

Scheme 9. 


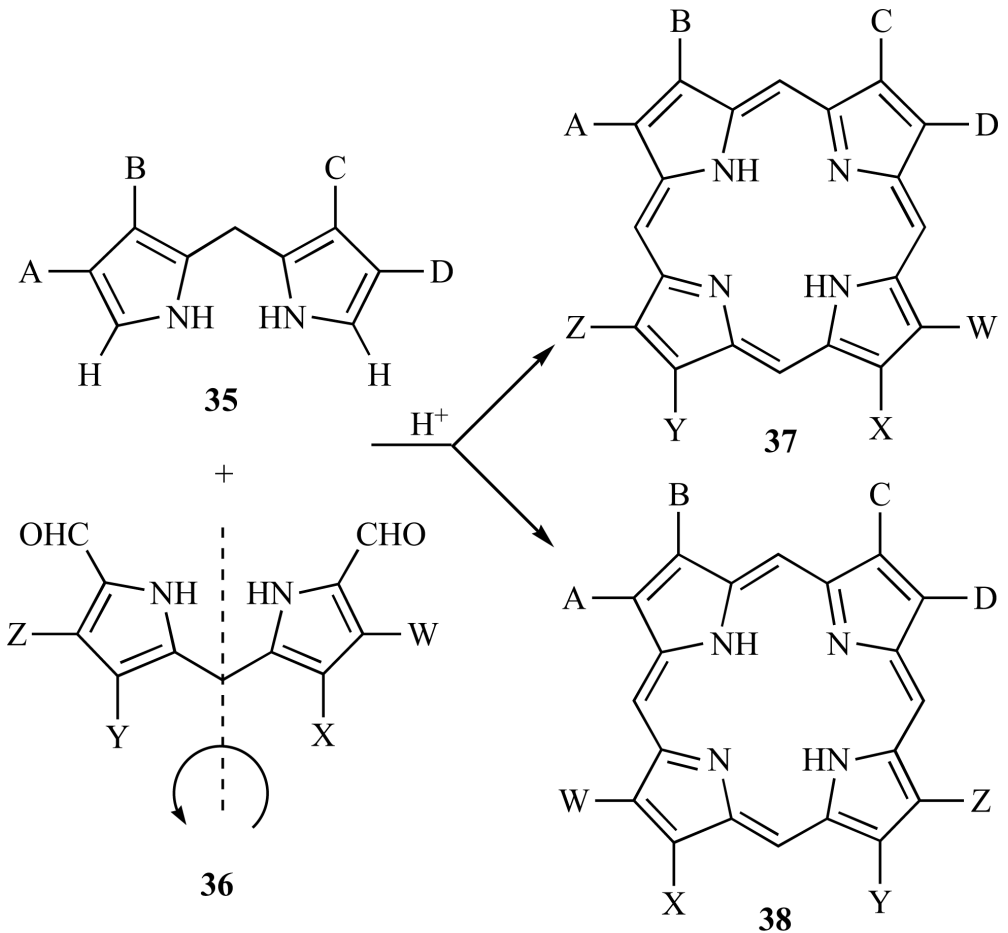

Scheme 10. 
<smiles>[R]c1[nH]c(Cc2[nH]c([R])c(CC)c2CC)c(C)c1C</smiles>

$39 \mathrm{R}=\mathrm{H}$

$40 \mathrm{R}=\mathrm{CO}_{2} \mathrm{H}$
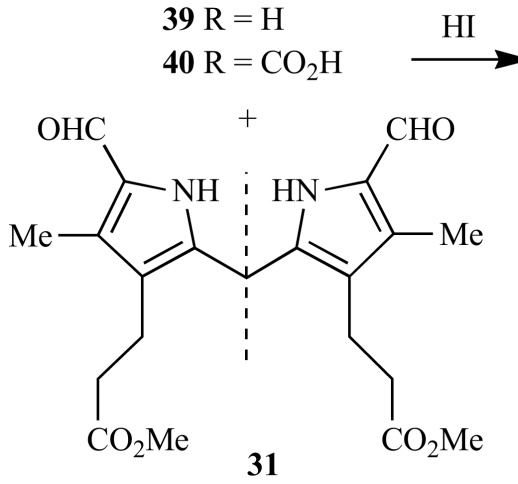<smiles>C=C1N=C(/C=c2\[nH]c(=C)c(C)c2CC)C(C)=C1C</smiles>

Scheme 11. 


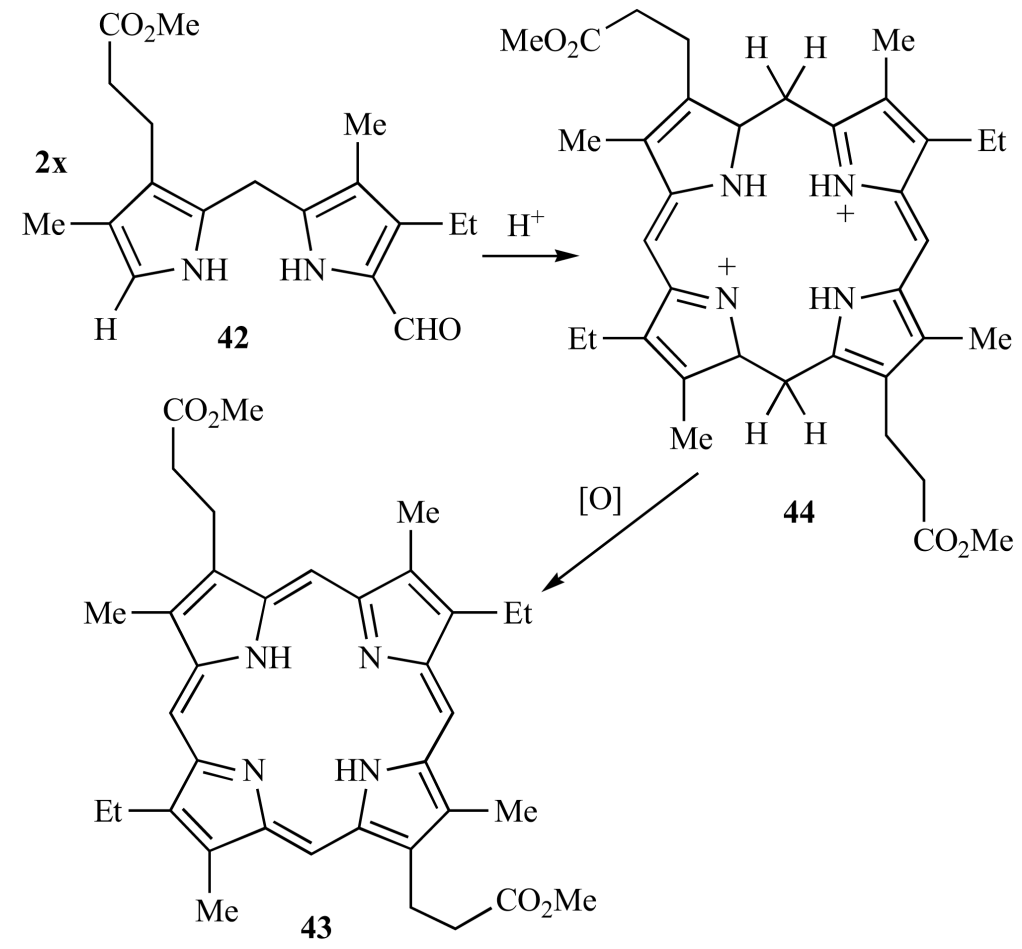

Scheme 12.

Curr Org Synth. Author manuscript; available in PMC 2015 February 01. 
<smiles>CC(=O)c1c(I)[nH]c(Cc2[nH]c(I)c(C)c2C(C)=O)c1C</smiles><smiles>O=C(O)COC(=O)C(=O)O</smiles>

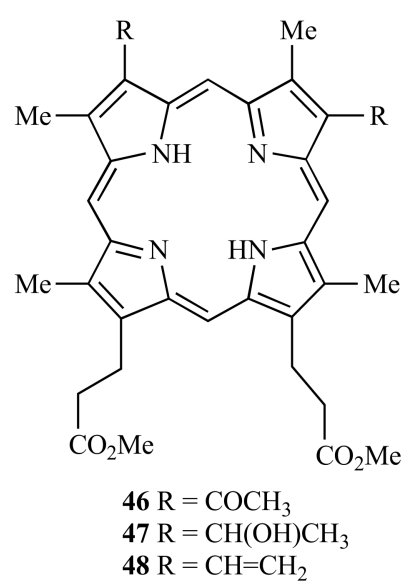

Scheme 13. 

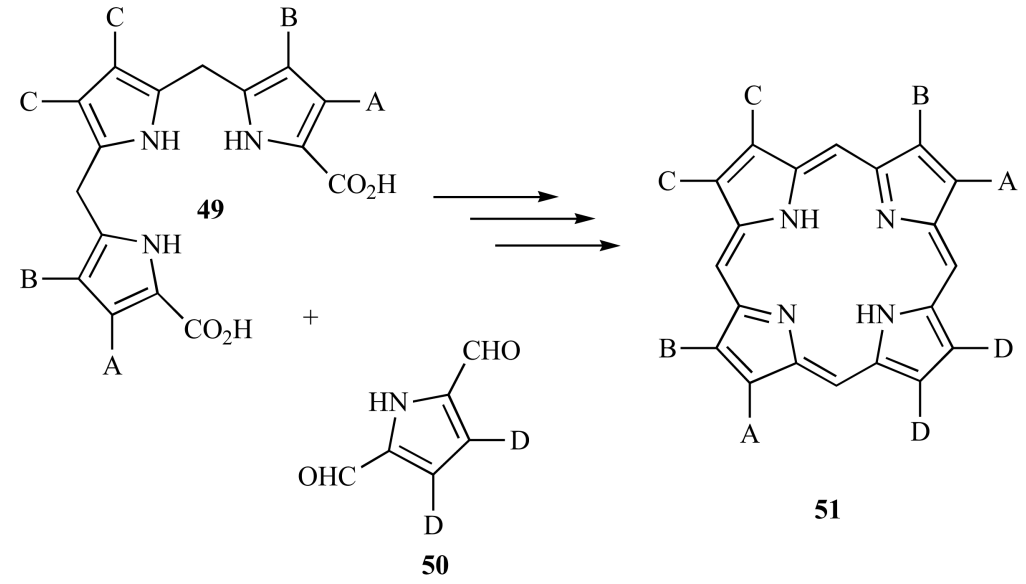

51

Scheme 14.

Curr Org Synth. Author manuscript; available in PMC 2015 February 01. 


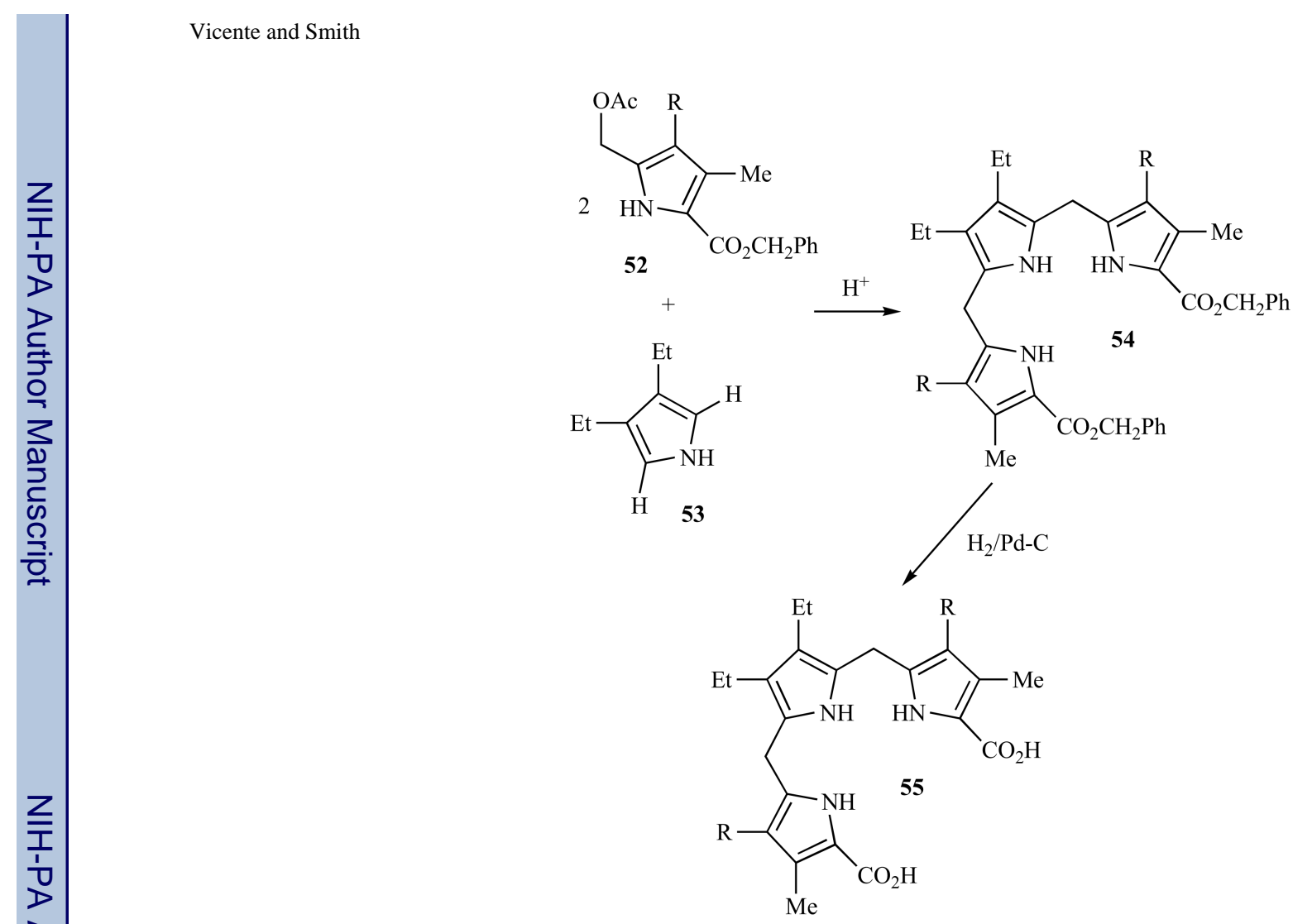

Scheme 15.

Curr Org Synth. Author manuscript; available in PMC 2015 February 01. 


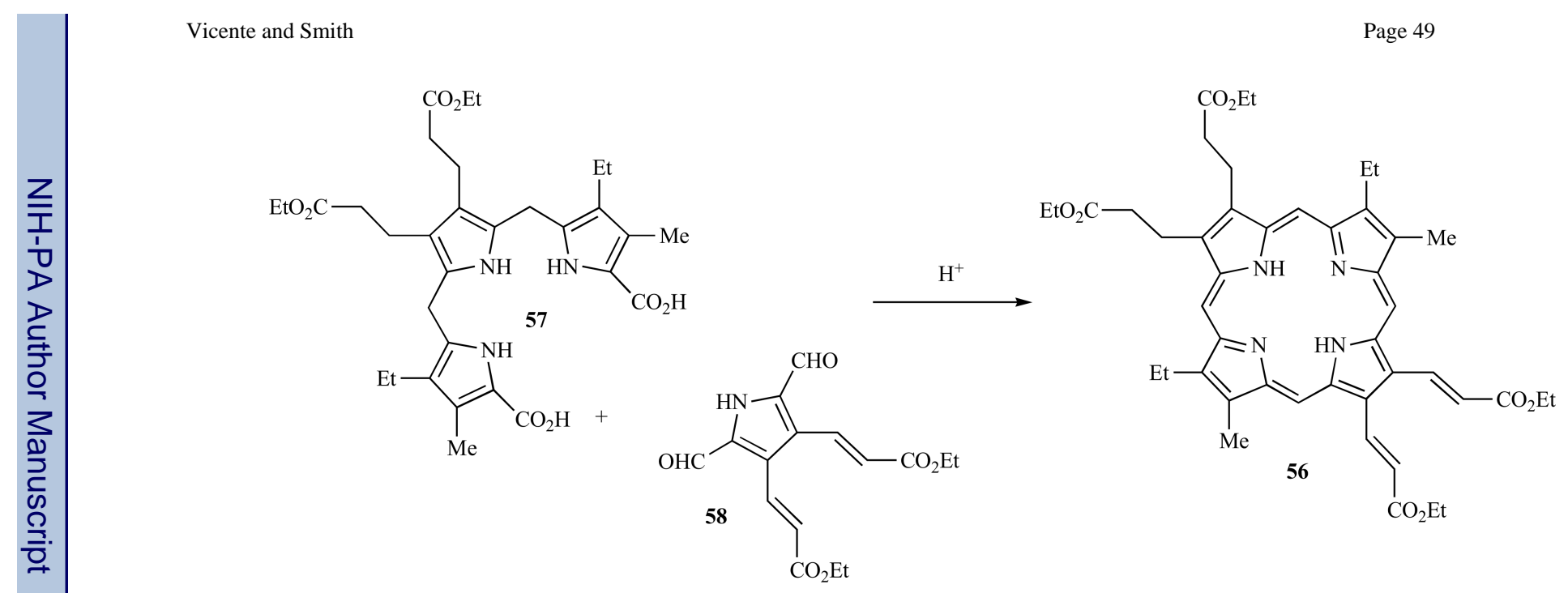

Scheme 16.

Curr Org Synth. Author manuscript; available in PMC 2015 February 01. 

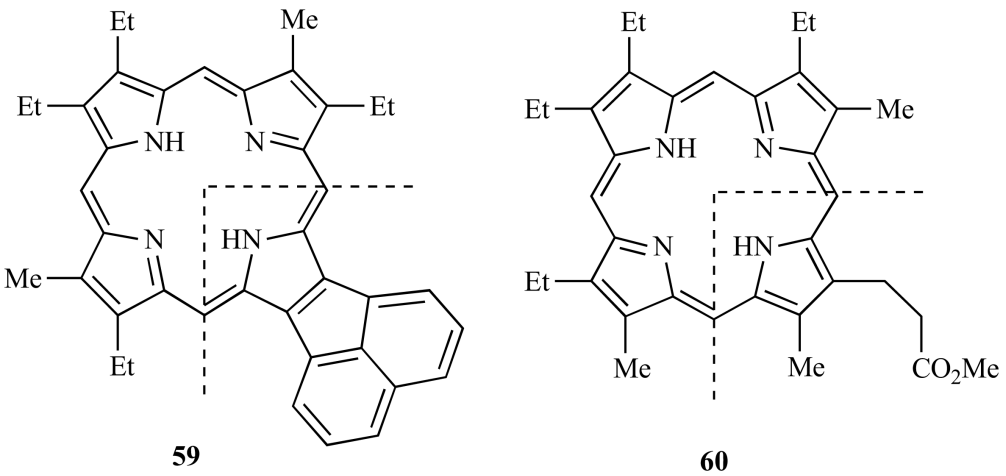

Fig. (2).

Lash's 3+1 products. 


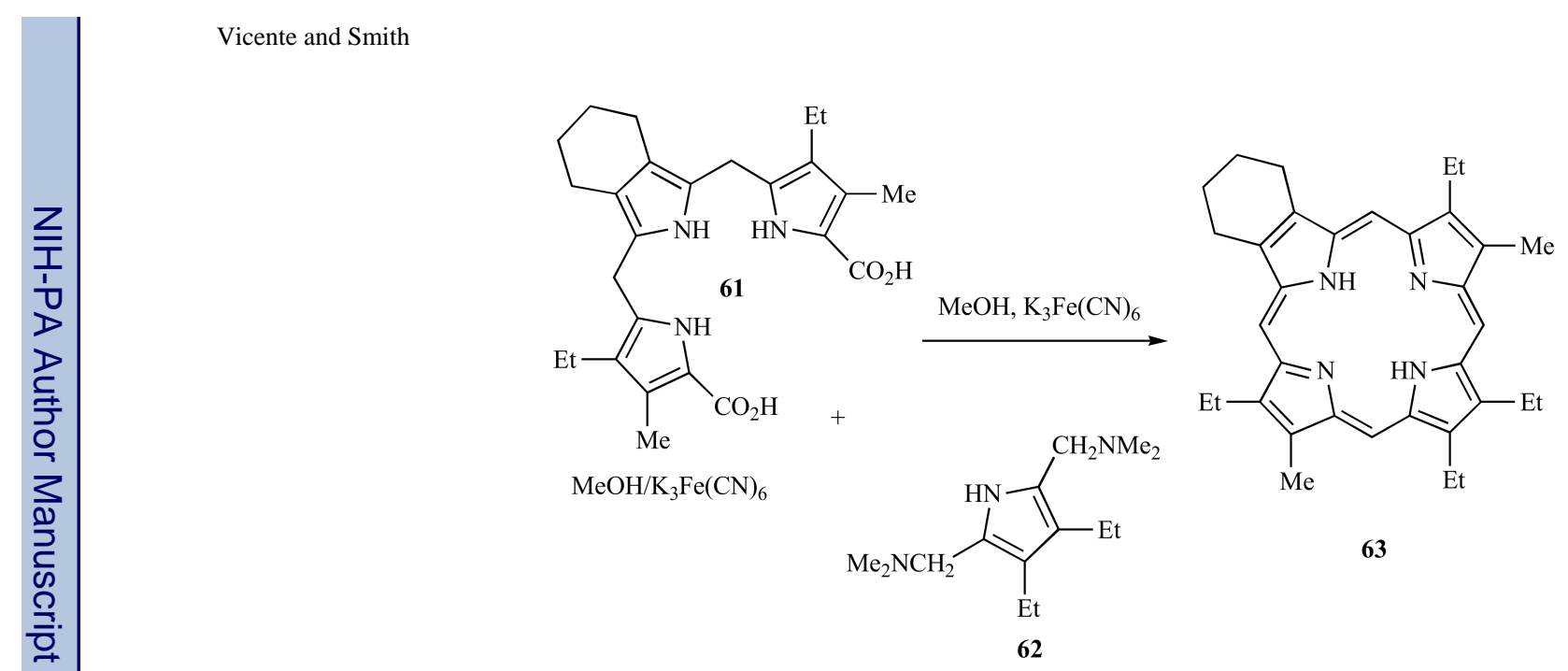

Scheme 17. 
<smiles>CCc1c(C)[nH]c(C=O)c1C</smiles>

65<smiles>CC(=O)CCc1c(Cc2[nH]c(C(=O)O)c(C)c2CCC(C)=O)[nH]c(C(=O)O)c1C</smiles>

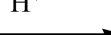<smiles>CCc1[nH]c(C)c(C)c1C</smiles><smiles>C=Cc1[nH]c(CC2=C(CCC(C)=O)C(C)=C(CCC(C)=O)[NH2+]2)c(CCC(C)=O)c1C</smiles>

$\mathrm{Cu}(\mathrm{OAc})_{2} / \mathrm{DMF}$ heat

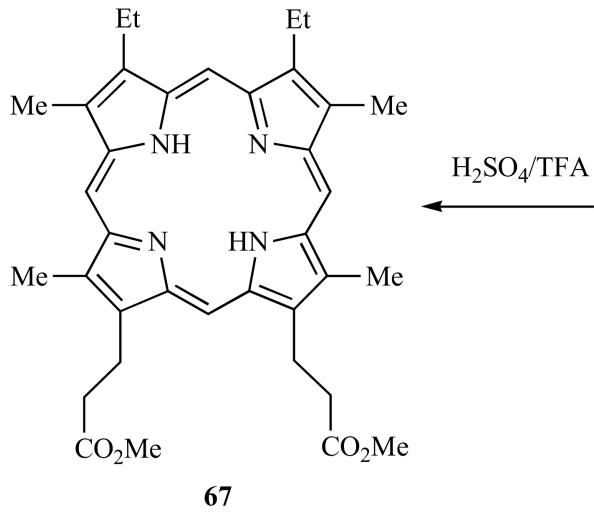

Scheme 18. 

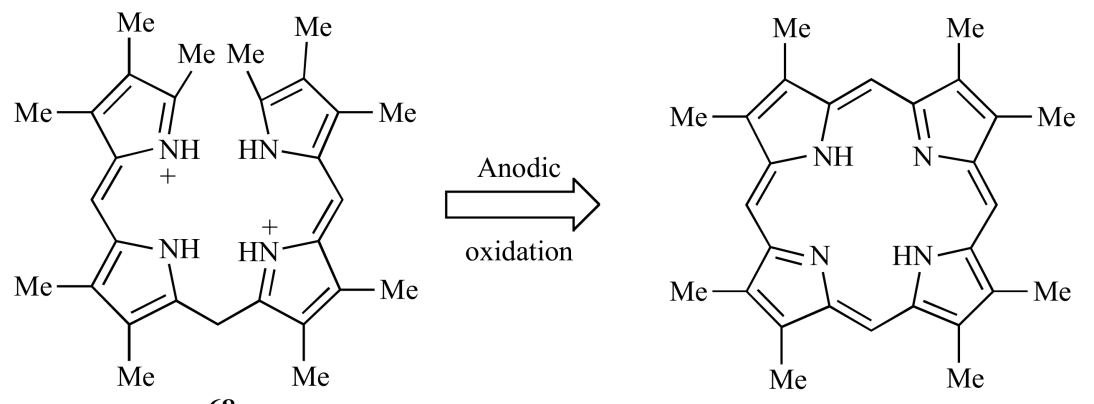

68
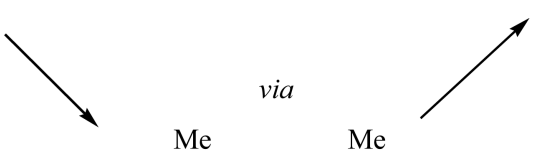

69

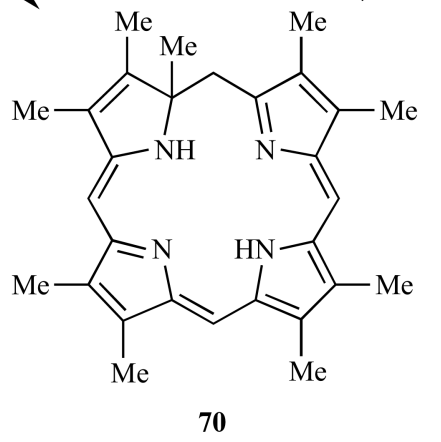

Scheme 19.

Curr Org Synth. Author manuscript; available in PMC 2015 February 01. 


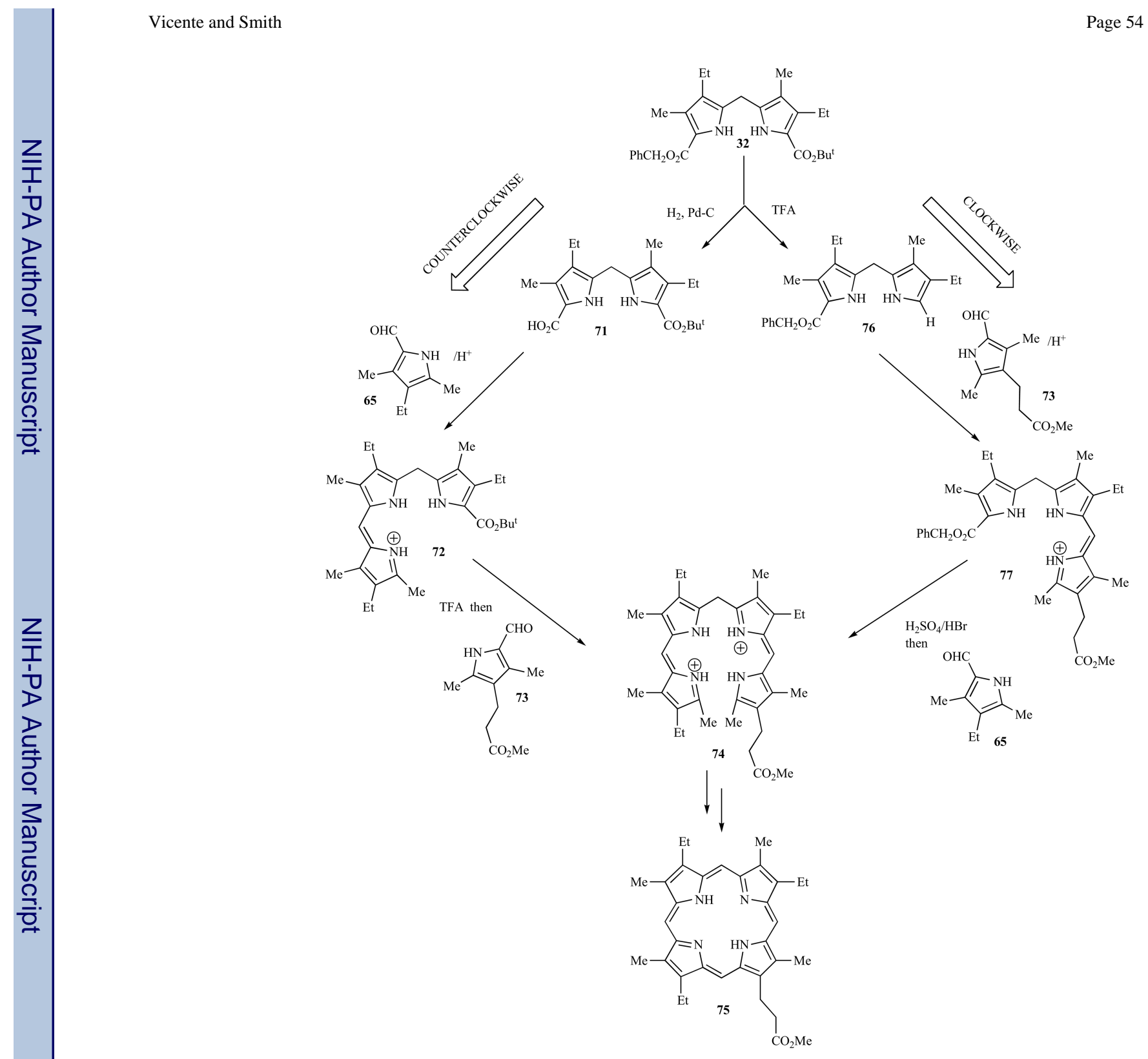

Scheme 20.

Curr Org Synth. Author manuscript; available in PMC 2015 February 01. 


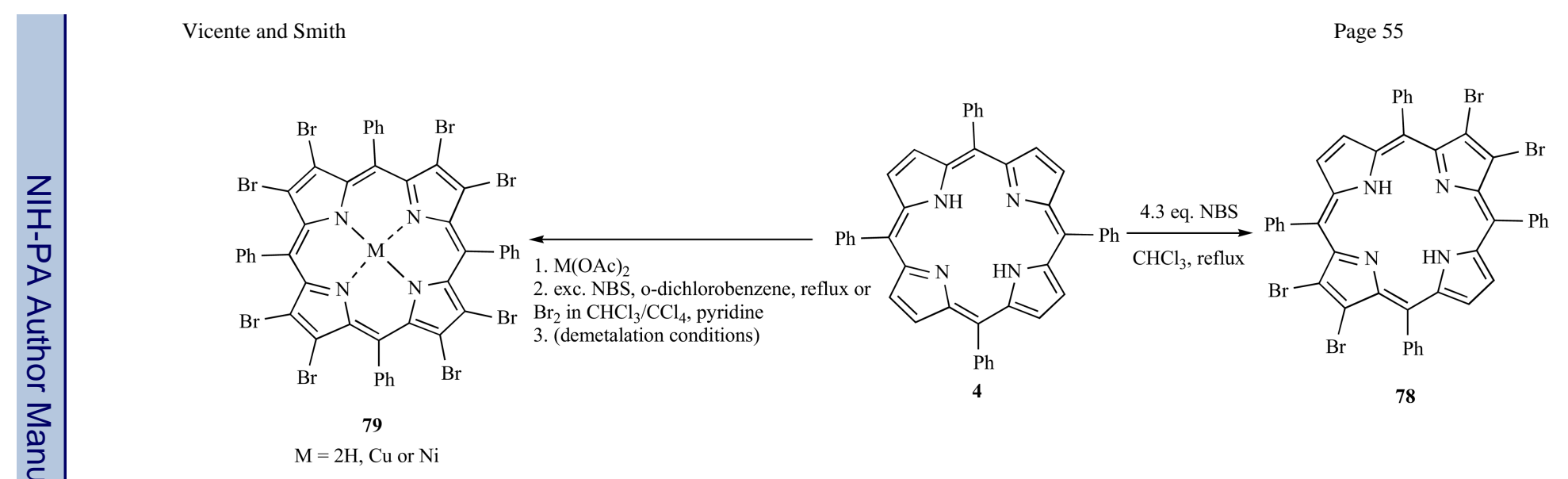

Scheme 21. 

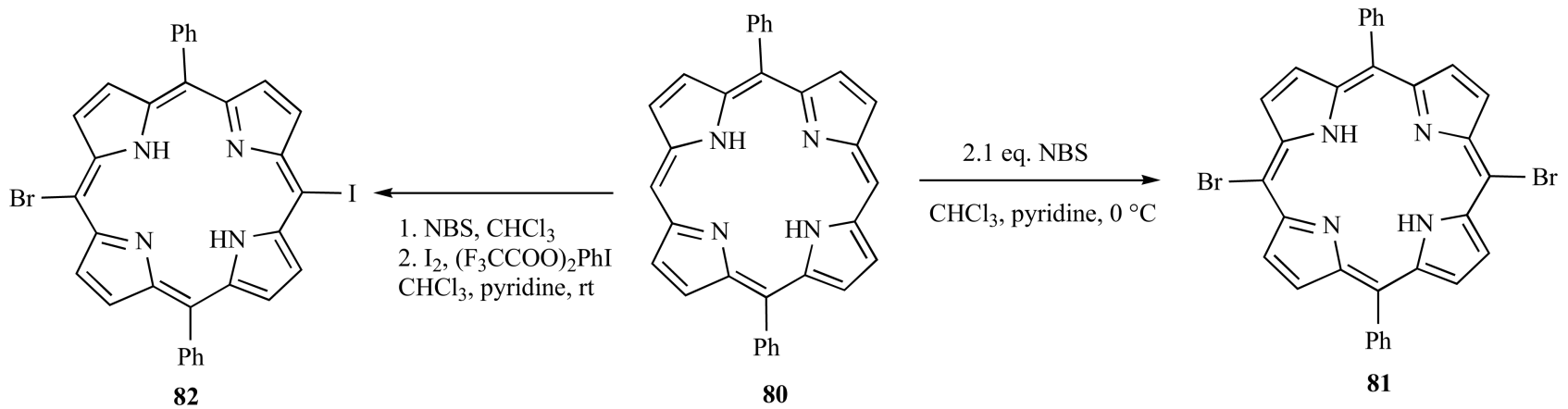

Scheme 22. 


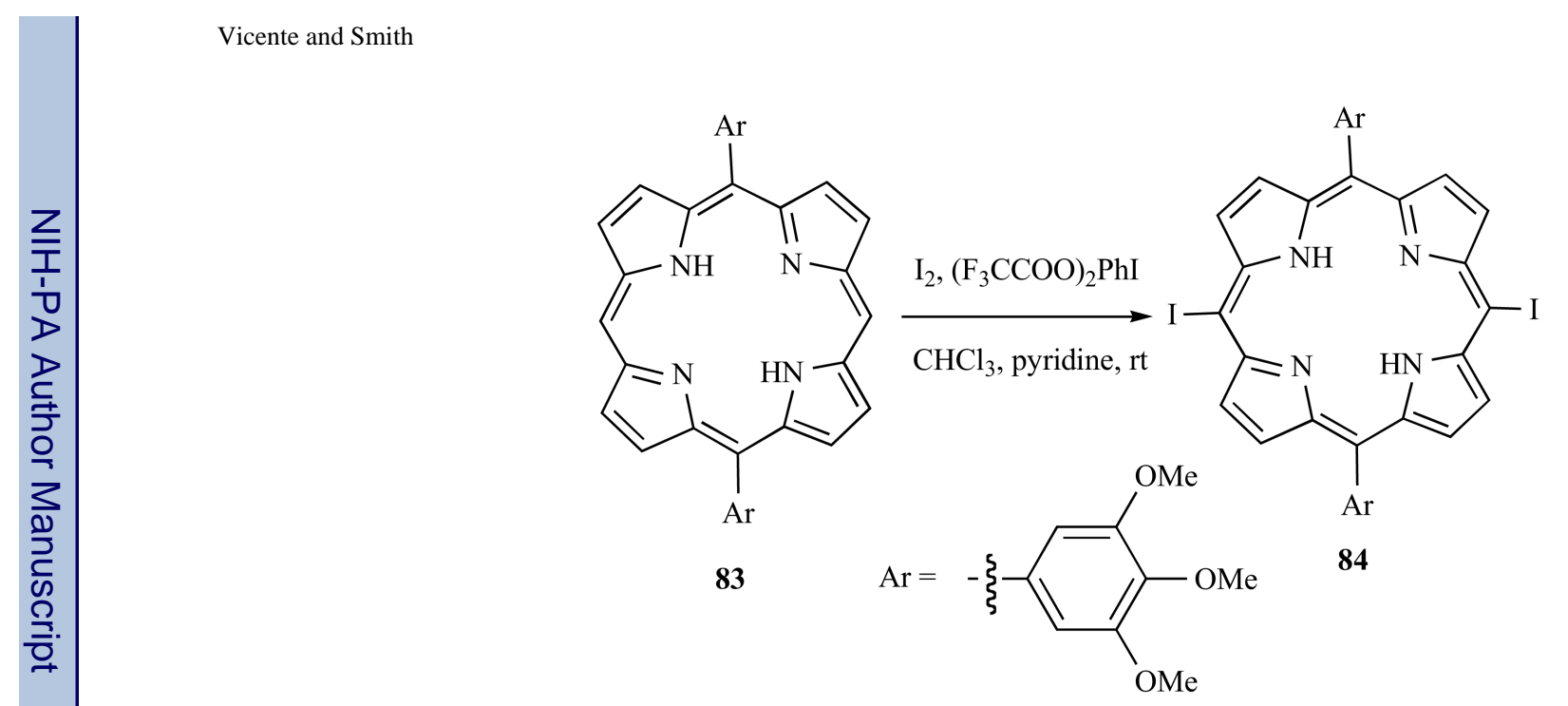

Scheme 23 . 


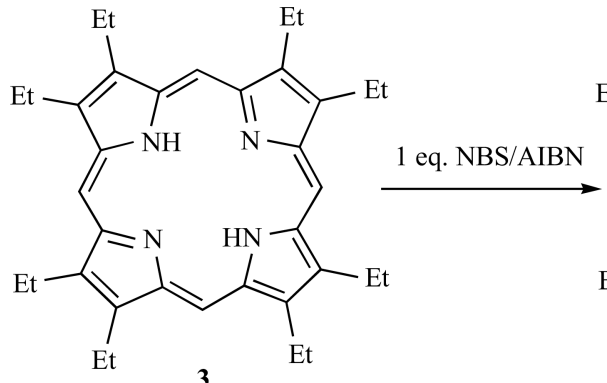<smiles>CCC1=C(CC)C(/C=c2\[nH]/c(=C\C3=N/C(=C\c4[nH]c(/C=C/Br)c(CC)c4CC)C(CC)=C3CC)c(CC)c2CC)=N1</smiles>

Scheme 24 . 


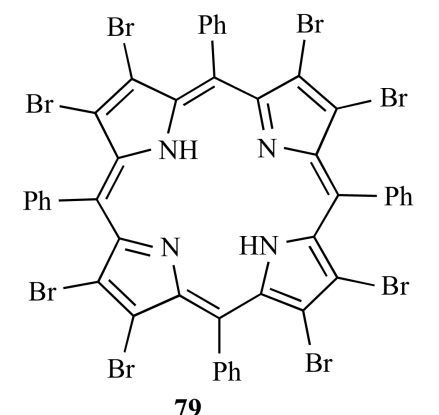

79

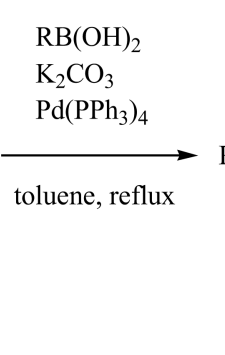

$\mathrm{K}_{2} \mathrm{CO}_{3}$

$\longrightarrow$<smiles></smiles>



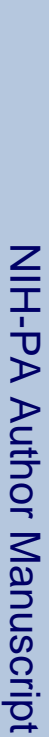

Scheme 25.

Curr Org Synth. Author manuscript; available in PMC 2015 February 01. 


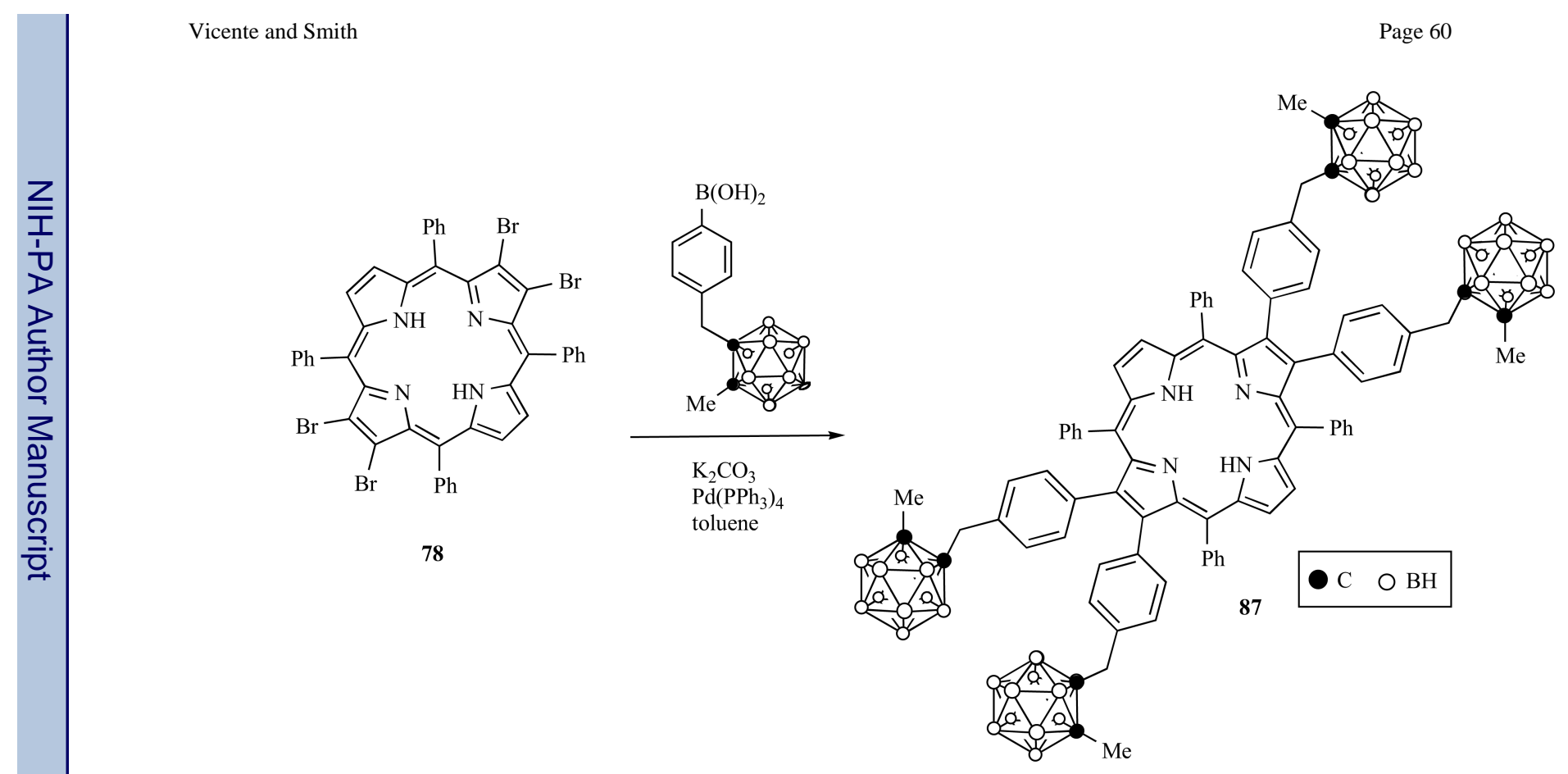

Scheme 26. 


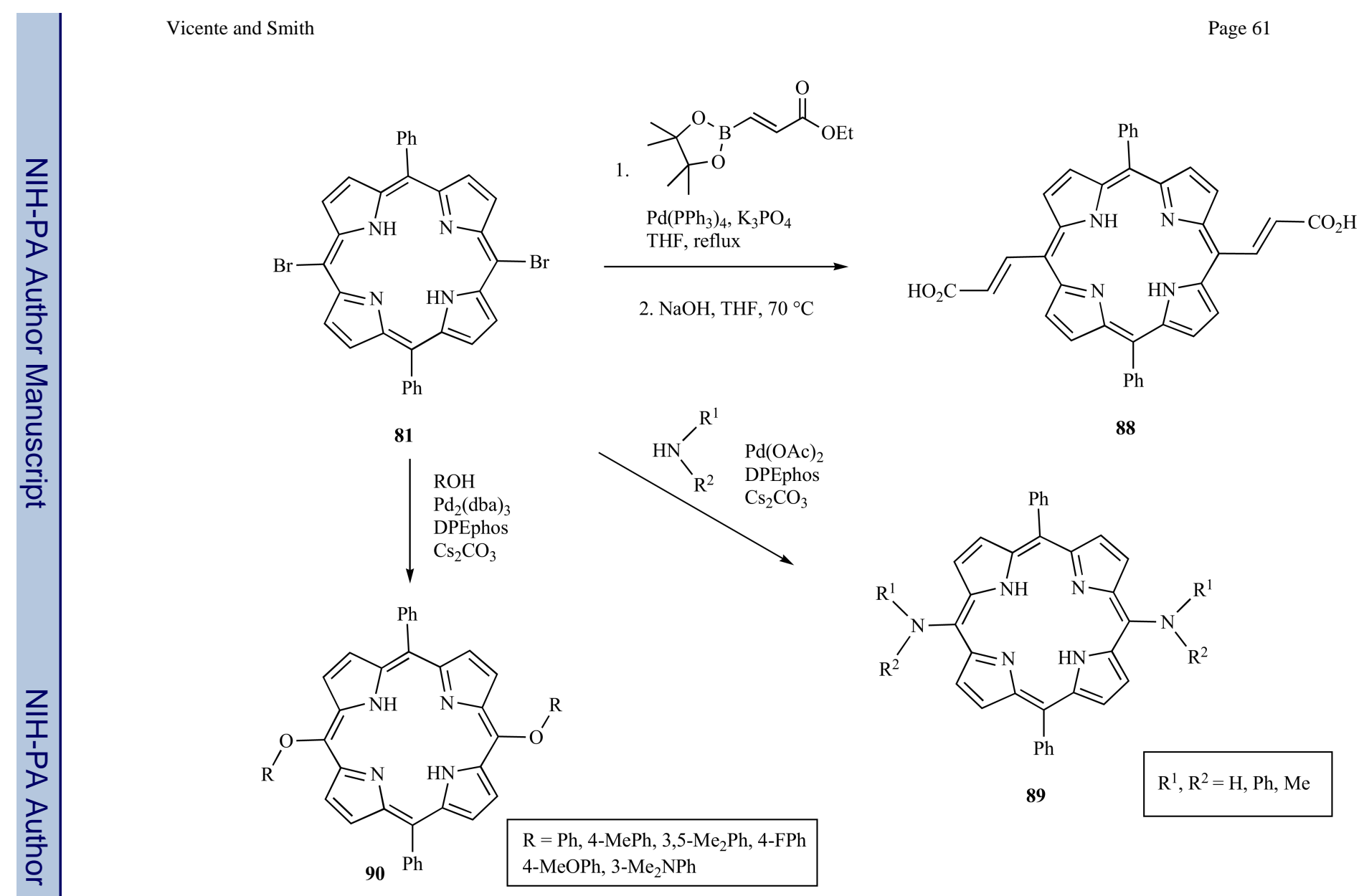

Scheme 27.

Curr Org Synth. Author manuscript; available in PMC 2015 February 01. 
1. NBS, $\mathrm{CHCl}_{3}$
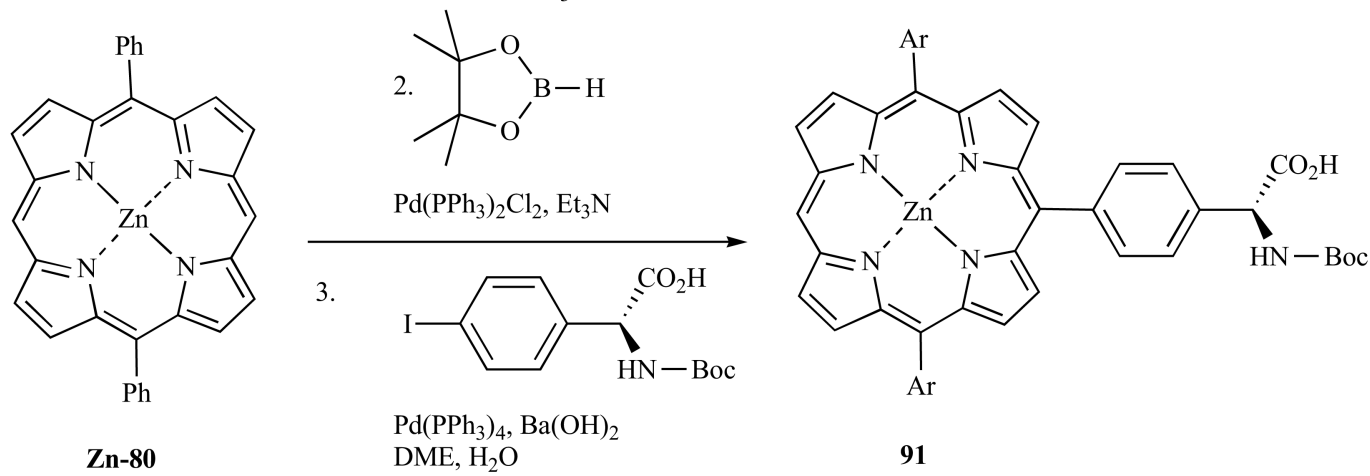

Scheme 28.

Curr Org Synth. Author manuscript; available in PMC 2015 February 01. 


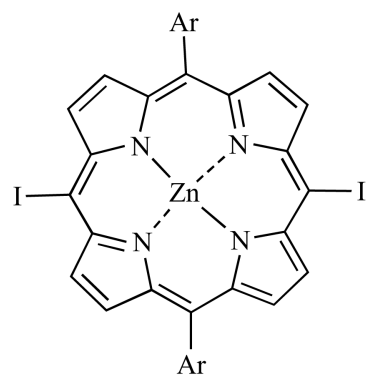

Zn-84

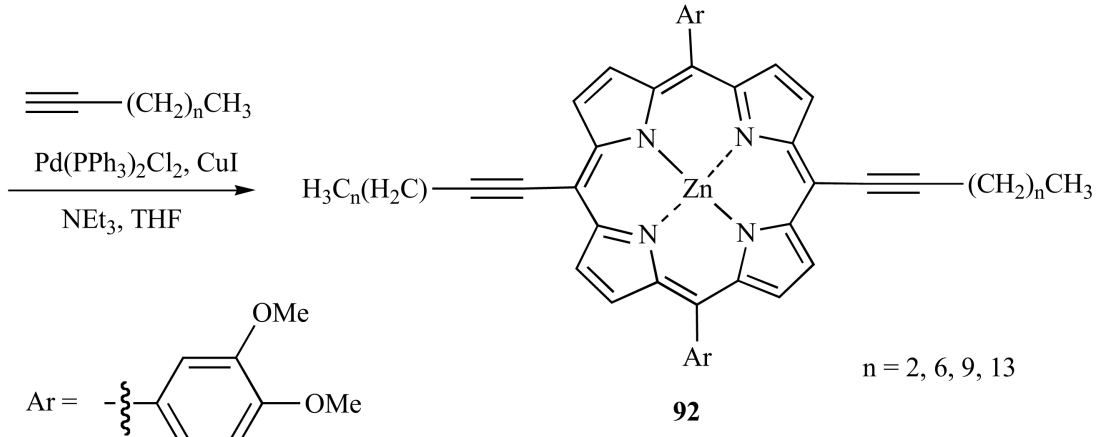

$\mathrm{OMe}$

Scheme 29.

Curr Org Synth. Author manuscript; available in PMC 2015 February 01. 

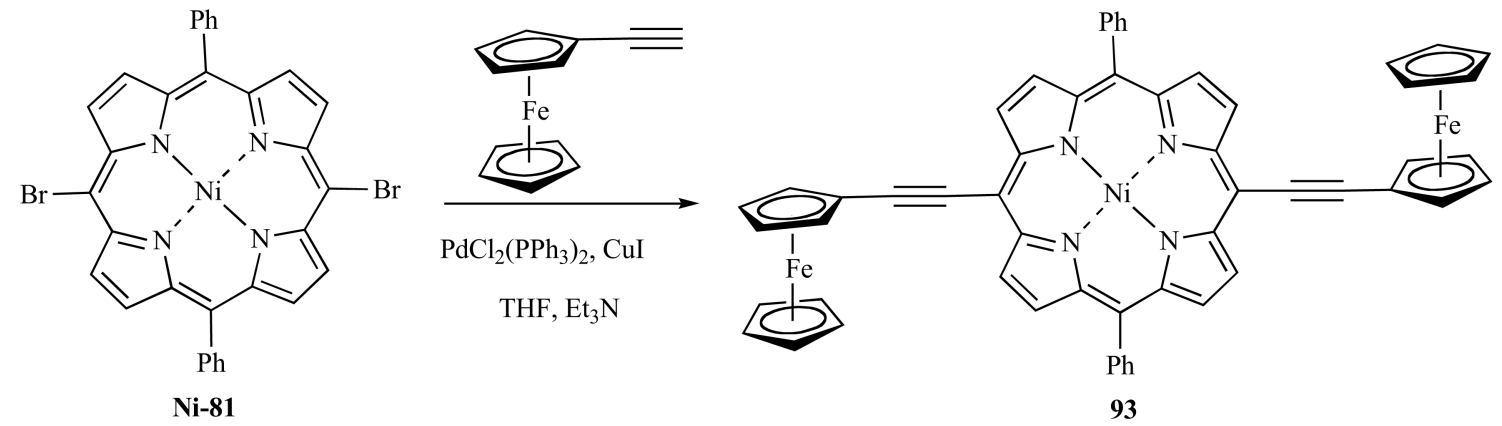

Scheme 30.

Curr Org Synth. Author manuscript; available in PMC 2015 February 01. 

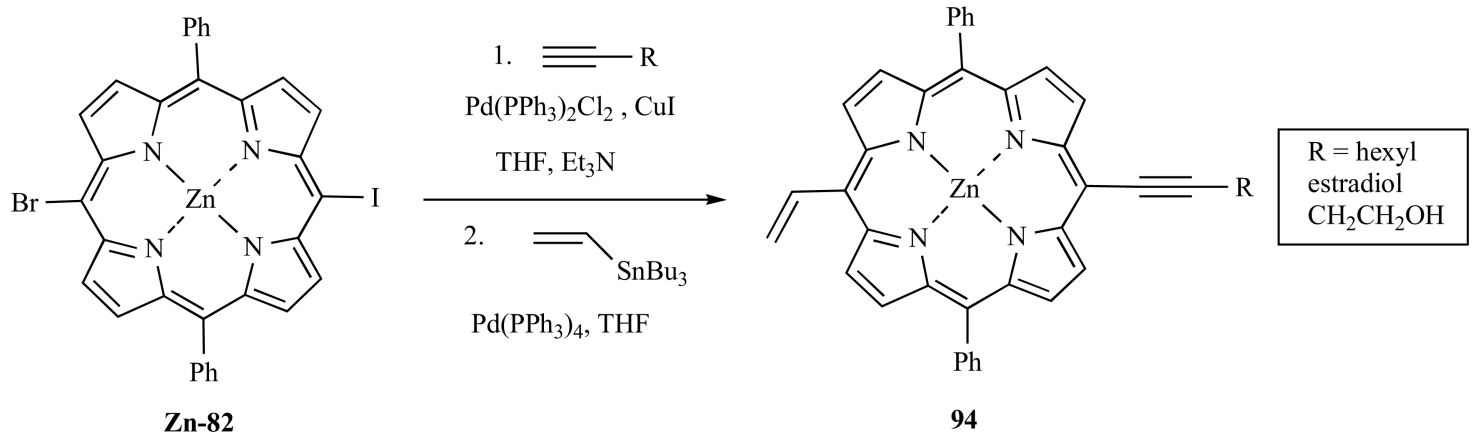

Scheme 31 .

Curr Org Synth. Author manuscript; available in PMC 2015 February 01. 

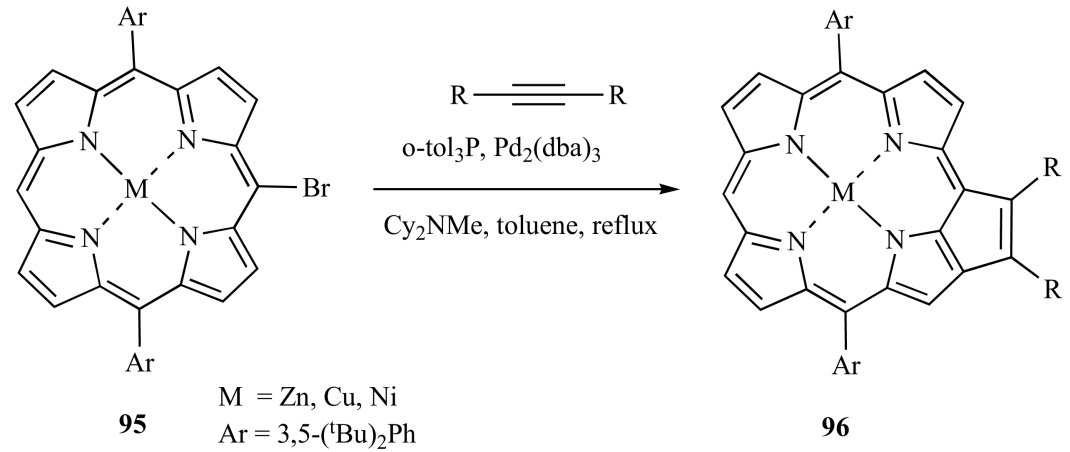

$\begin{aligned} \mathrm{R}= & \mathrm{Ph}, \mathrm{nPr}, \\ & \text { 2-thienyl } \\ & 4-\mathrm{CF}_{3} \mathrm{Ph} \\ & 4-\mathrm{OMePh}\end{aligned}$

Scheme 32.

Curr Org Synth. Author manuscript; available in PMC 2015 February 01. 

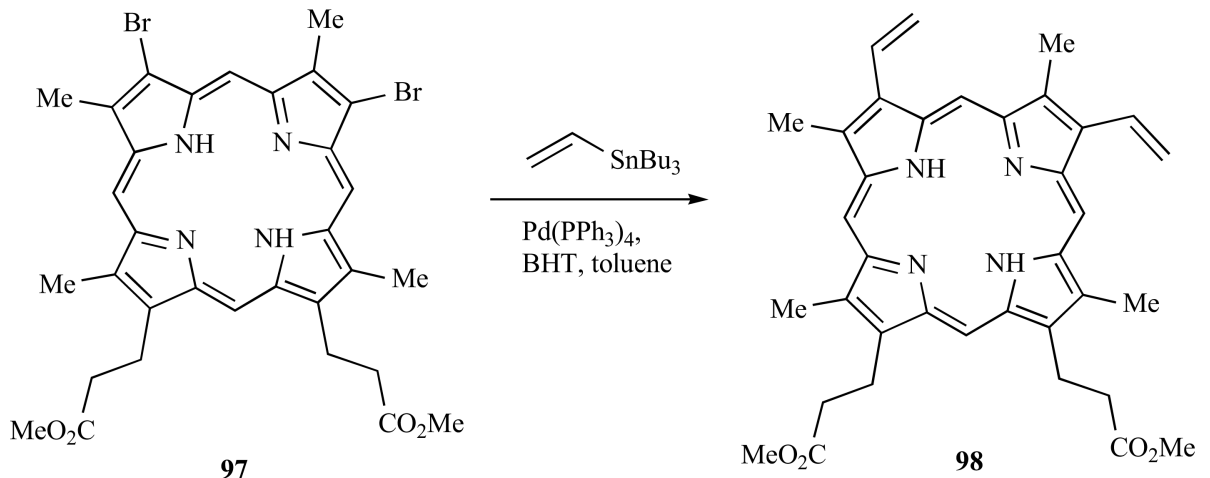

Scheme 33.

Curr Org Synth. Author manuscript; available in PMC 2015 February 01. 


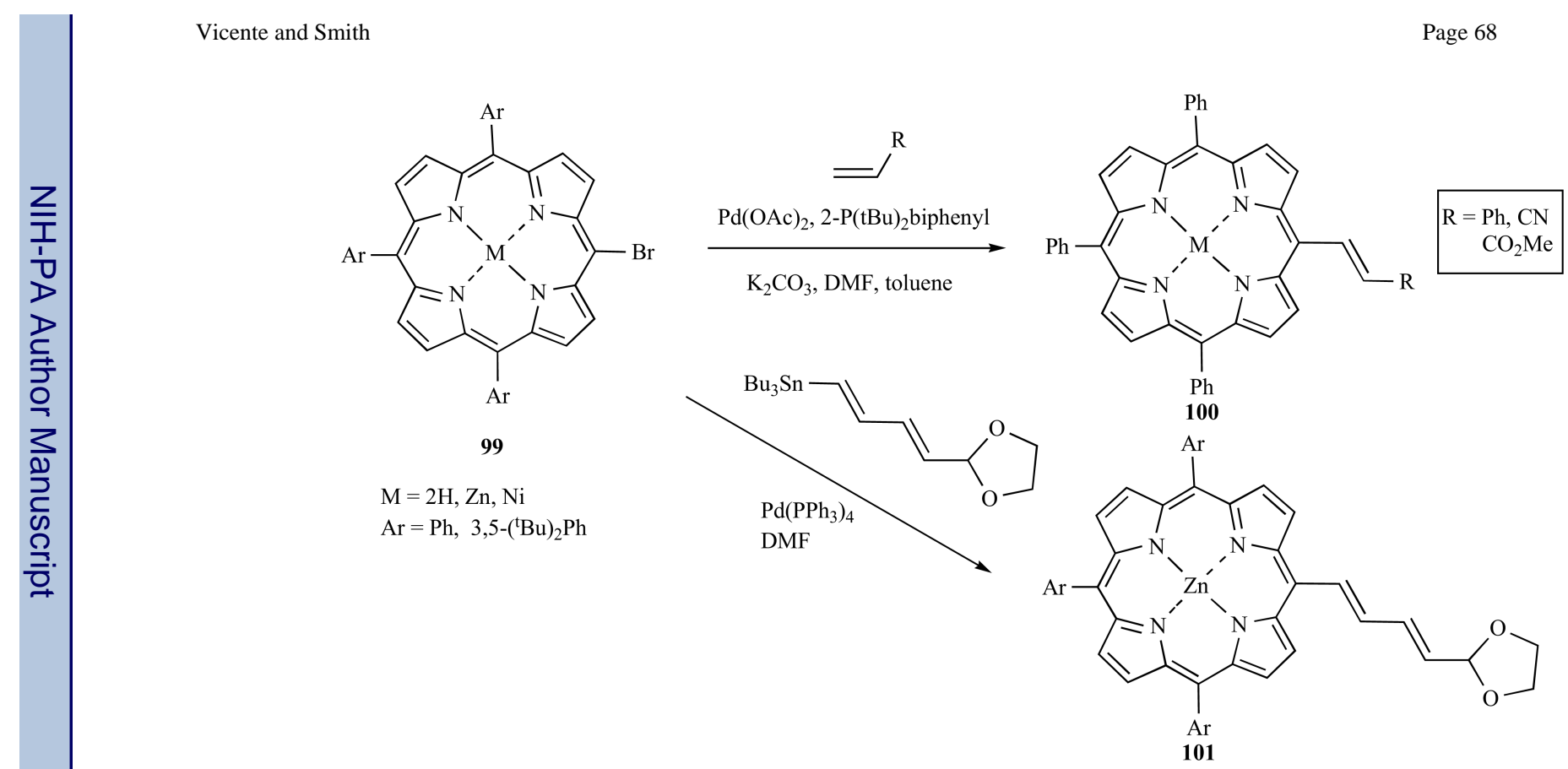

Scheme 34. 

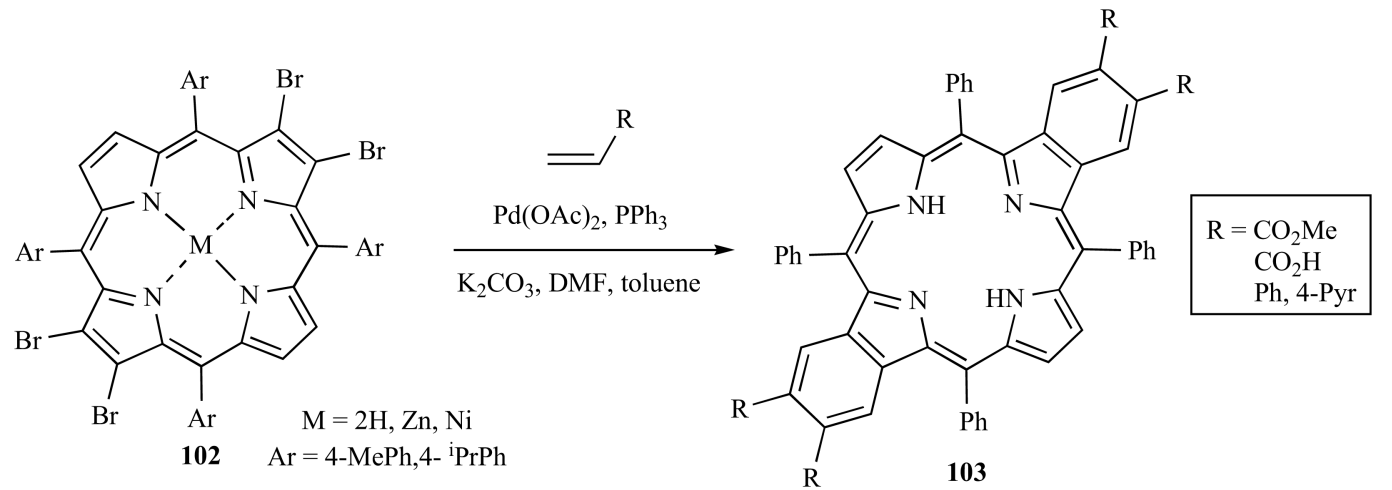

Scheme 35.

Curr Org Synth. Author manuscript; available in PMC 2015 February 01. 


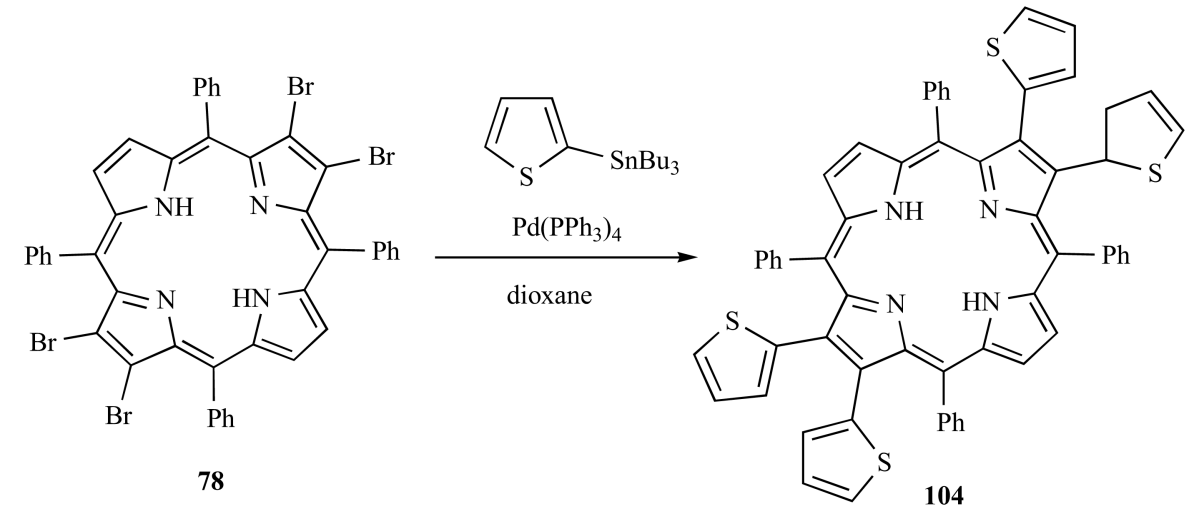

Scheme 36.

Curr Org Synth. Author manuscript; available in PMC 2015 February 01. 

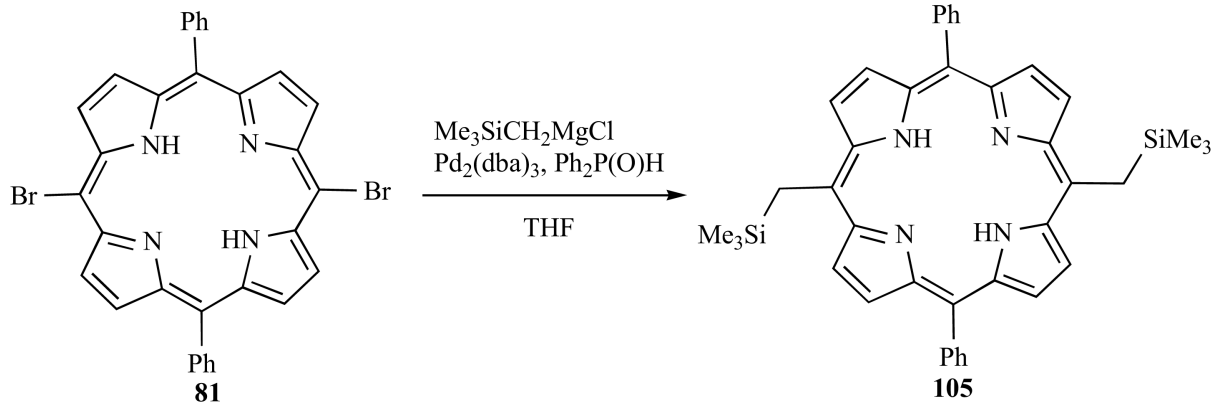

Scheme 37. 


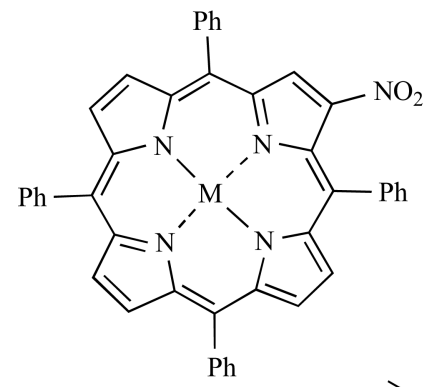

106

$\mathrm{M}=\mathrm{Cu}, \mathrm{Ni}, \mathrm{Zn}$

$$
\mathrm{CH}_{2}\left(\mathrm{CO}_{2} \mathrm{Me}\right)_{2}
$$

NaOMe, THF, DBU

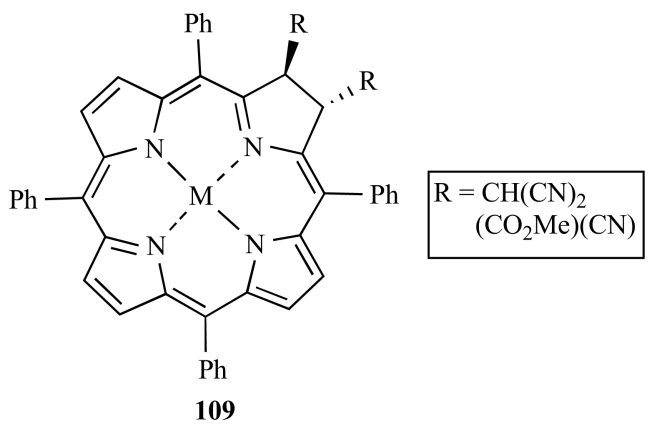

Scheme 38.

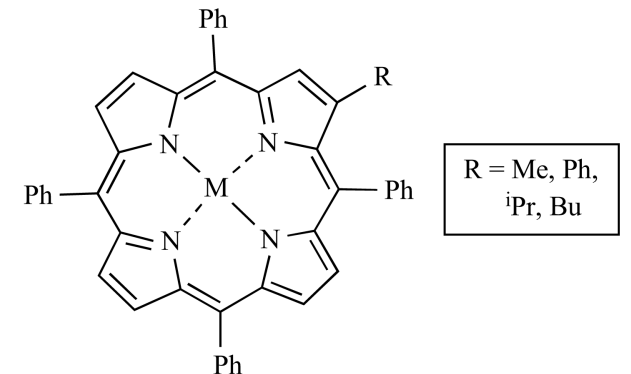

107

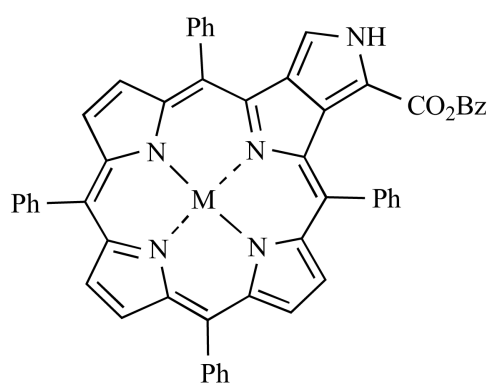

Curr Org Synth. Author manuscript; available in PMC 2015 February 01. 


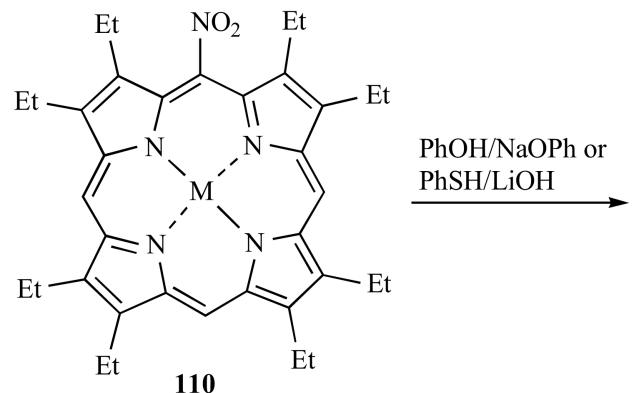

$\mathrm{M}=2 \mathrm{H}, \mathrm{Cu}$ or $\mathrm{Ni}$

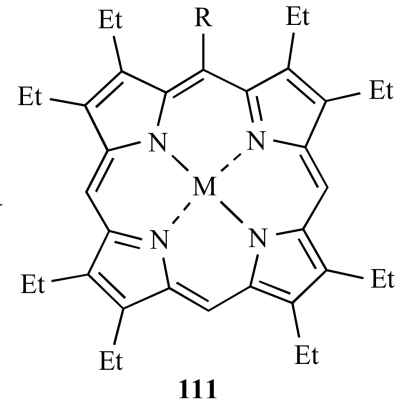

$\mathrm{R}=\mathrm{SPh}, \mathrm{OPh}$

Scheme 39. 

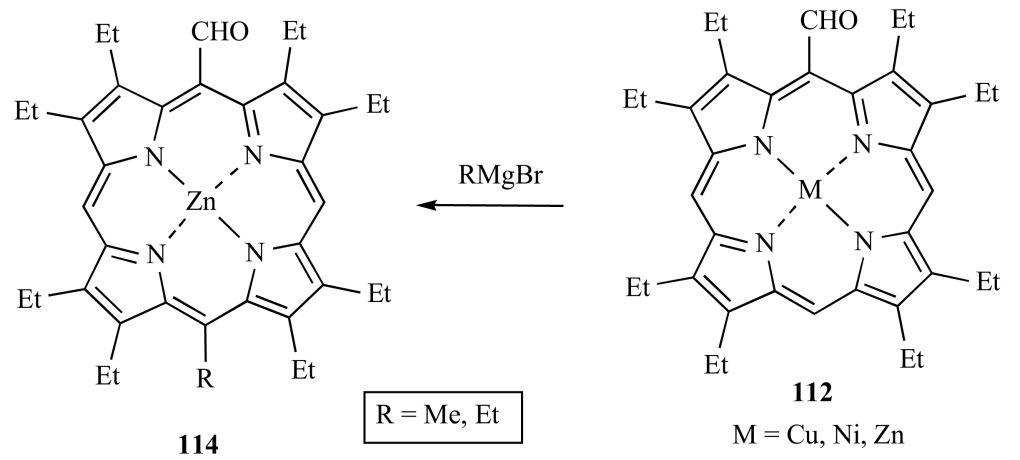

\section{$\mathrm{TiCl}_{3}(\mathrm{DME})_{1.5}$} $\mathrm{Zn}-\mathrm{Cu}, \mathrm{DME} 90^{\circ} \mathrm{C}$

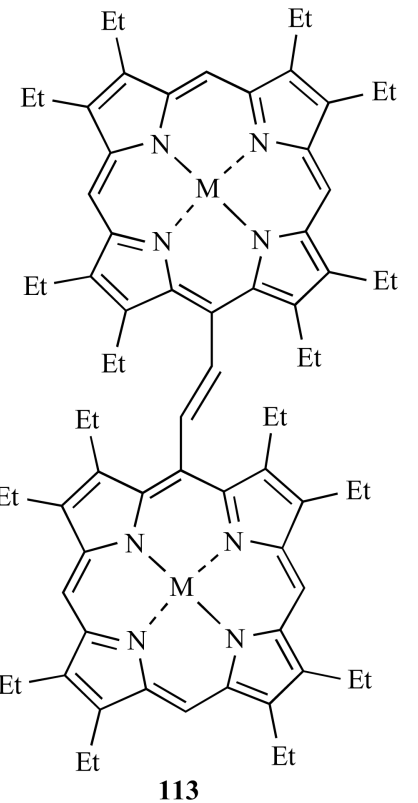

Scheme 40.

Curr Org Synth. Author manuscript; available in PMC 2015 February 01. 


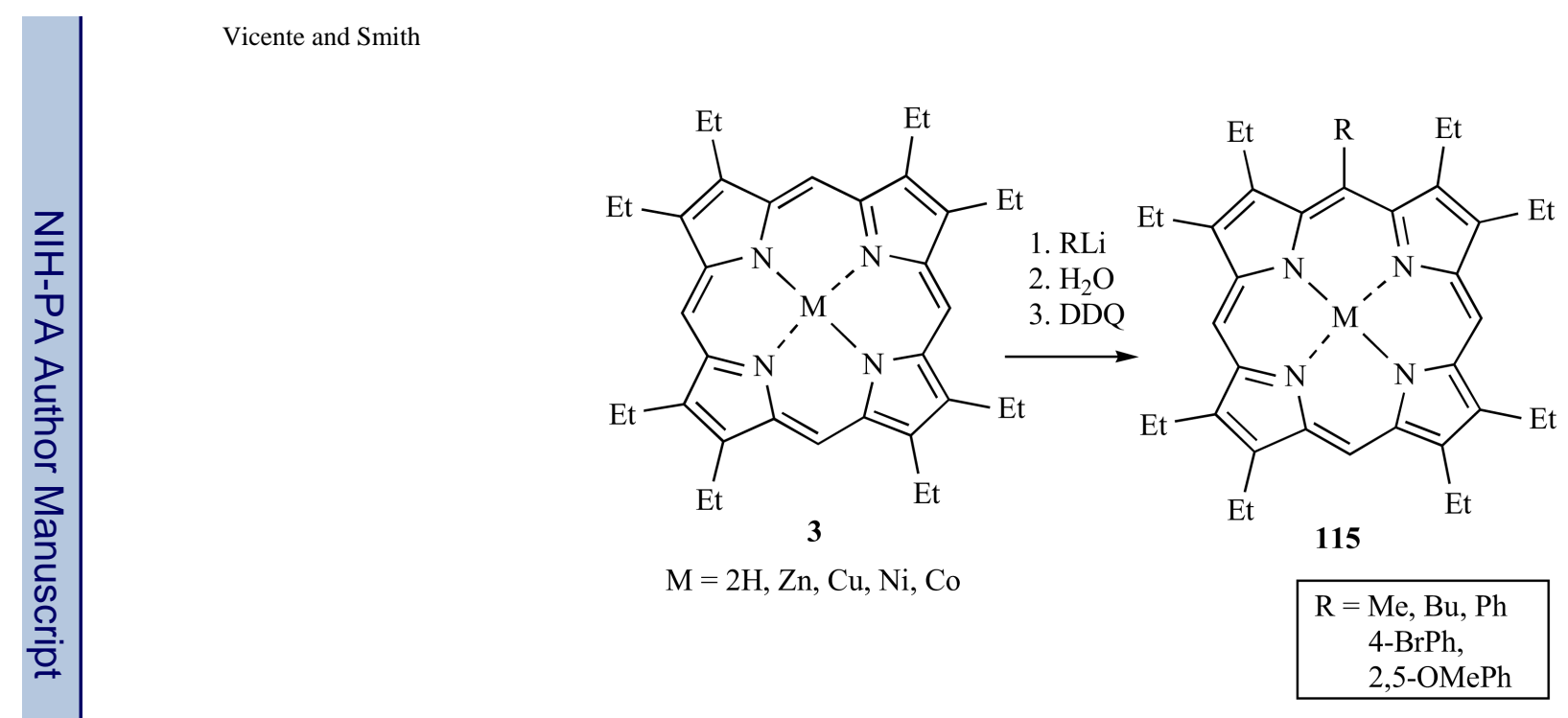

Scheme 41. 


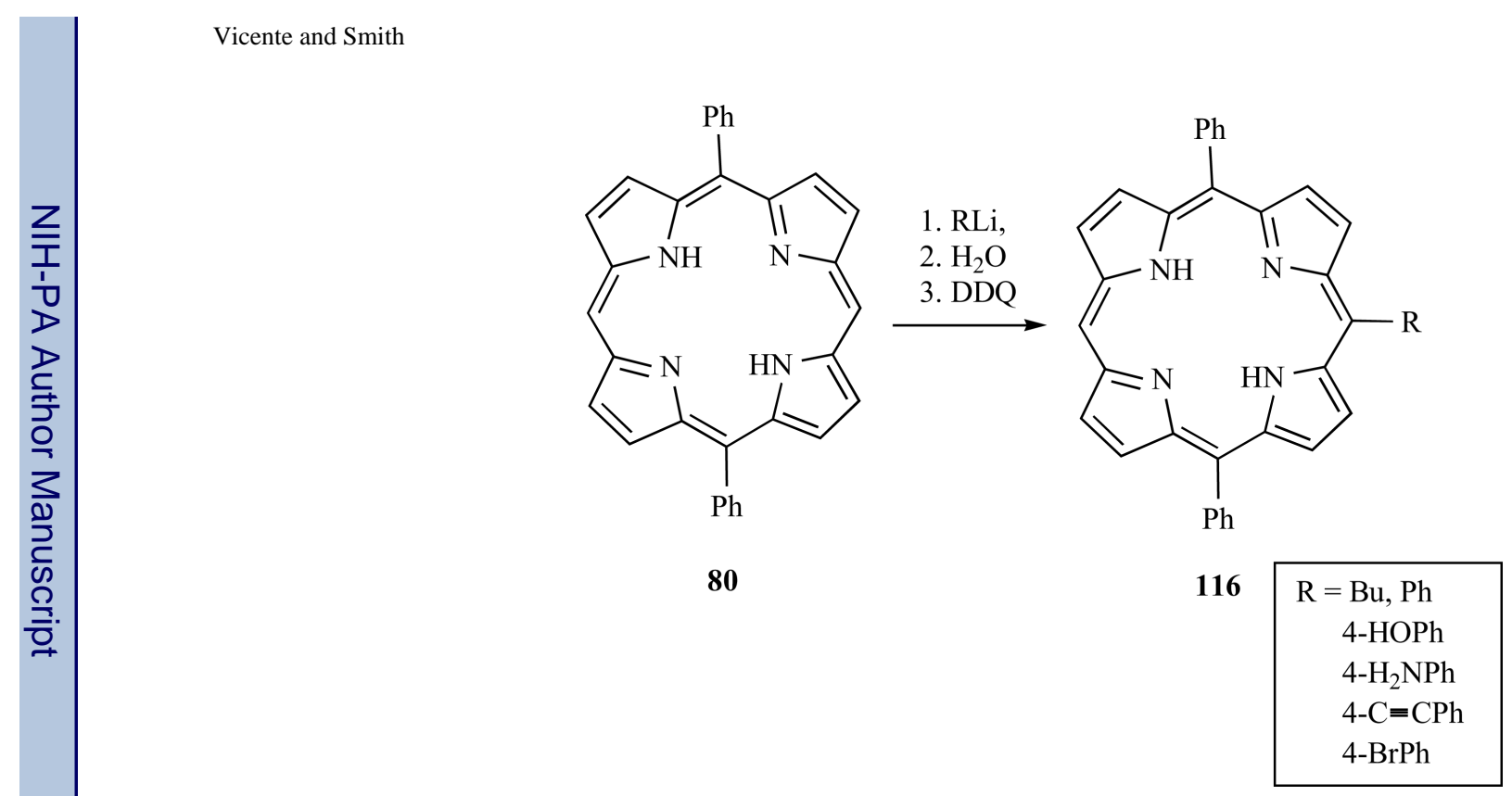

Scheme 42.

Curr Org Synth. Author manuscript; available in PMC 2015 February 01. 


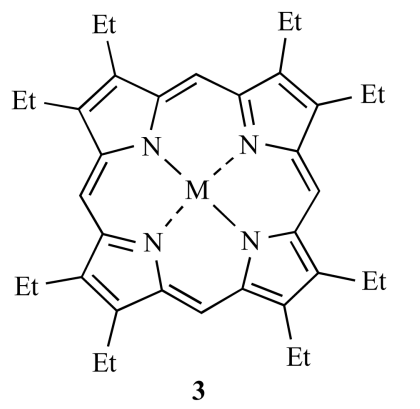

$\mathrm{M}=2 \mathrm{H}, \mathrm{Zn}, \mathrm{Mg}$

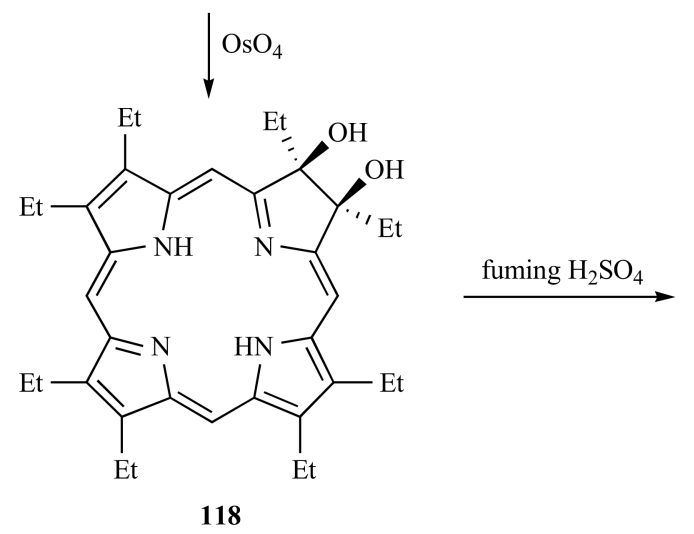

Scheme 43.

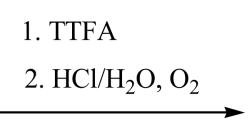<smiles>CCC1=N/C(=C/c2[nH]c(C=c3[nH]c(=Cc4[nH]c(C(=O)C5=NC(CC)=C5CC)c(CC)c4CC)[nH]3)c(CC)c2CC)C(CC)=C1CC</smiles><smiles></smiles>

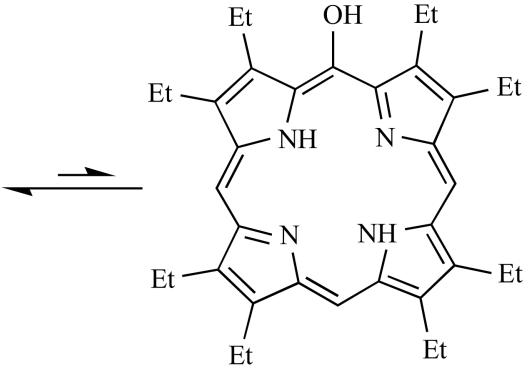

117

Curr Org Synth. Author manuscript; available in PMC 2015 February 01. 
<smiles></smiles><smiles>O=C(O)OC(=O)OC(=O)C(=O)O</smiles><smiles></smiles>

Scheme 44. 